\title{
War and Politics: The Neoconservative Plan for Iraq
}

\author{
By \\ Mark Muhanad Ayyash, B.A. \\ A thesis submitted to the Faculty of Graduate Studies \\ and Research in partial fulfillment of the \\ requirements for the degree of \\ Master of Arts \\ Department of Sociology and Anthropology \\ Carleton University \\ Ottawa, Ontario
}

August 27, 2005

(C) copyright

2005, Mark Muhanad Ayyash 


$\begin{array}{ll}\begin{array}{l}\text { Library and } \\ \text { Archives Canada }\end{array} & \begin{array}{l}\text { Bibliothèque et } \\ \text { Archives Canada }\end{array} \\ \begin{array}{l}\text { Published Heritage } \\ \text { Branch }\end{array} & \begin{array}{l}\text { Direction du } \\ \text { Patrimoine de l'édition }\end{array} \\ \begin{array}{l}\text { 395 Wellington Street } \\ \text { Ottawa ON K1A ON4 }\end{array} & \begin{array}{l}\text { 395, rue Wellington } \\ \text { Ottawa ON K1A ON4 } \\ \text { Canada }\end{array}\end{array}$

Your file Votre référence

ISBN: 0-494-10034-6

Ourfile Notre référence

ISBN: 0-494-10034-6

NOTICE:

The author has granted a nonexclusive license allowing Library and Archives Canada to reproduce, publish, archive, preserve, conserve, communicate to the public by telecommunication or on the Internet, loan, distribute and sell theses worldwide, for commercial or noncommercial purposes, in microform, paper, electronic and/or any other formats.

The author retains copyright ownership and moral rights in this thesis. Neither the thesis nor substantial extracts from it may be printed or otherwise reproduced without the author's permission.
AVIS:

L'auteur a accordé une licence non exclusive permettant à la Bibliothèque et Archives Canada de reproduire, publier, archiver, sauvegarder, conserver, transmettre au public par télécommunication ou par l'Internet, prêter, distribuer et vendre des thèses partout dans le monde, à des fins commerciales ou autres, sur support microforme, papier, électronique et/ou autres formats.

L'auteur conserve la propriété du droit d'auteur et des droits moraux qui protège cette thèse. $\mathrm{Ni}$ la thèse ni des extraits substantiels de celle-ci ne doivent être imprimés ou autrement reproduits sans son autorisation.
In compliance with the Canadian

Privacy Act some supporting forms may have been removed from this thesis.

While these forms may be included in the document page count, their removal does not represent any loss of content from the thesis.
Conformément à la loi canadienne sur la protection de la vie privée, quelques formulaires secondaires ont été enlevés de cette thèse.

Bien que ces formulaires aient inclus dans la pagination, il n'y aura aucun contenu manquant.

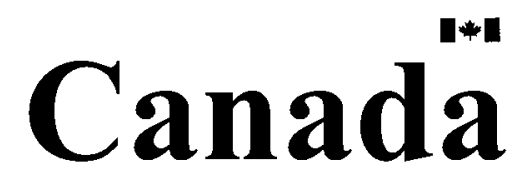




\begin{abstract}
:
This thesis utilizes a Foucauldian method to investigate the discourse of a neoconservative movement largely responsible for the decision to invade Iraq. After describing its important components, an outline of the discourse's two main features is provided: two-level thinking, and the tension of 'isolationism-expansionism'. These features are brought into focus through an examination of the two-step plan for Iraq. This examination leads us to believe that a Clausewitzian view of war is what makes the plan theoretically possible. A critical engagement with Clausewitz's work is thus followed, and a paradox within this work is presented. This paradox raises important questions for the neoconservative plan. It is concluded that the discourse's architects fail to adequately deal with the main question this paradox raises: how is it possible to quickly undertake a transition from war to politics? This failure seriously questions this movement's viability as an intellectual basis for foreign policy making.
\end{abstract}




\section{Acknowledgments:}

I like to thank my committee members Dr. Alan Hunt, Dr. Pat O'Malley, and Dr. John Sigler for all of the useful comments, suggestions, and questions they have raised. These have greatly strengthened my work. I also thank Dr. Derek Smith and Dr. Neil Gerlach for helping me develop some of the ideas for this thesis during my first year in the MA program. 


\section{Contents}

Introduction

\section{Section One:}

1 An Exploration of the Internationalist Neoconservative Discourse

2 Targeting Saddam: The Two-Step Plan

\section{Section Two:}

3 War and Politics: An Inquiry into Clausewitz

4 The Two-Step Plan in Context

5 War, What is it Good for?

Conclusion

Bibliography

Appendix A

Appendix B 


\section{Introduction}

\section{'NeoConservatism and the Iraq War - Background and Thesis Programmatic'}

This thesis utilizes the Foucauldian method of discourse analysis to seek a better understanding of the intellectual, social, and political forces behind the American invasion of Iraq on March 19, 2003. The massive wave of global objection to the war has led many in the social, economic, political, and legal academic spheres to raise important questions about the morality, the economic and diplomatic feasibility, and the legality of the war. In all of these efforts, however, no attempt at understanding the discourse of the war proponents has been undertaken ${ }^{1}$. This will be the concern of this project. Before stating the research questions around which this analysis revolves, I will briefly provide a historical overview of the discourse in question.

The 'Iraq question' - or more accurately the 'Saddam Hussein question" ${ }^{\text {? }}$ - has been the source of many debates within US administrations, beginning with George $\mathrm{H}$. Bush and leading into the administration of George W. Bush. Throughout this period, different approaches towards Saddam were adopted, and many others discarded. The approach that was eventually realized with the invasion has its sources in a particular strand of American neoconservative discourse ${ }^{3}$. More specifically, it concerns the

\footnotetext{
${ }^{1}$ This point will be further discussed in the methodology and literature review sections.

${ }^{2}$ The discussion in Chapters One and Two will clarify why Saddam, not Iraq per se, was the real concern within this discourse.

${ }^{3}$ The term 'neoconservative' is intriguing. In his study, Kenneth Zagacki (1996) lays out the main features of the neoconservative discourse which emerged in the 1960s. One of these features dealt with how this discourse actively sought to defeat neo-liberals (Zagacki 1996: 174) and conservatives (1996: 173) alike: "Neoconservatives depicted politics as endorsing rational action that promoted the social welfare - less action than liberals but more enlightened action than that proposed by traditional conservatives." (1996: 177) Essentially, they presented themselves as mediators who utilized the best of classic liberalism,
} 
'internationalists' of the political Right. They consist of a group of intellectuals whose main task is to tackle two important questions in the sphere of foreign affairs. What does the international sphere look like? And what should America's role in it be? It was within this discourse that the idea of using war to deal with the 'Saddam question' was developed ${ }^{4}$. The chief architects of this discourse include important political and intellectual figures such as Robert Kagan, William Kristol ${ }^{5}$, Richard Perle, and Paul Wolfowitz. They began formulating their ideas during the latter part of the 1980s, but the materialization of those ideas into a coherent plan did not seem to occur until the late 1990s (see Mann 2003 \& Klare 2003) ${ }^{6}$. Since the first inauguration of George W. Bush as President of the United States and the events of $9 / 11$, these intellectual architects have moved their ideas beyond the realm of a coherent plan and into the realm of a dominant one. During the last five years, their ideas and visions came to form a basis for American National Defense Strategy and Foreign Policy.

Two years since this war began, the massive global protest against it has waned, and most of the academic focus has begun to shift towards the 'what now' questions. In a sense, this academic and public shift in attention is warranted. Questions surrounding the

\footnotetext{
conservatism, and the progressive elements of modernity (1996: 178-81). In this sense, these neoconservatives are as much progressive liberals as they are conservatives, and hence, the dubiousness of the term 'neoconservative'. This quote from editor Michael Scully sums up this point quite well: "neoconservatives are liberals who have been mugged by reality, while neoliberals are liberals who have been mugged by reality but refuse to press charges." (PNAC website: quoted in Schmitt July 2003) ${ }^{4}$ By war, I refer to the Clausewitzian definition: "An act of force to compel our adversary to do our will" (Clausewitz 1943: 264). Force deals with the deployment of the physical force of a nation-state (i.e. its military capabilities) in order to impose its will upon its enemy (1943: 265). In this particular case, the act of war is that which involves the US's deployment of its new military strategy and tactic: 'rapid dominance' and 'shock and awe' respectively. A few other points about what I mean by war will be pointed out in the literature review section surrounding the sociology of war.

${ }^{5}$ An interesting note here is that William is Irving Kristol's son - a very prominent architect of neoconservatism (see Zagacki 1996 for a summation of Irving Kristol's main ideas and contributions to the discourse).

${ }^{6}$ These dates and the ideas associated with them will be discussed in Chapters One and Two.
} 
extent of American power, its potential counterweights, the new world order, Iraq's insurgency, terrorism, and the future surrounding the rest of the 'axis-of-evil' trio (Iran and North Korea), raise many pertinent issues and impact important decisions yet to be made.

Nevertheless, I believe there remains one important question that is yet to be fully addressed: why war? Why did the most powerful nation of the world - this selfproclaimed guardian of civilization - resort to this most gruesome and volatile form of human intercourse? My interest in this question led me to the period preceding the invasion (1996-2003). I wanted to find out how it was that these neoconservative internationalists came to the decision of invading a militarily weak country halfway across the globe. While identifying their rationale for employing war, another question presented itself: putting aside one's moral reservations towards war $^{7}$, what is unique about the employment of war in a plan where it occupies a subordinate role to politics where war is utilized as a means to a political end rather than territorial appropriation, resource acquisition or colonization? More specifically, what does this Clausewitzian view of war mean to the specific plan promoted by this discourse? Ultimately, my analysis of the latter question aims to expand our knowledge of the relationship between war and politics, particularly in light of Michel Foucault's (2003) discussion on the matter in Society Must Be Defended. These are the two questions I will consider in this thesis. Thus, I will divide it into two sections. The first will deal with the former question, the second with the latter.

\footnotetext{
${ }^{7}$ I wish to avoid taking the position of the moral high ground in relation to the proponents of the war-effort. There is no reason to believe that they do not share similar moral reservations - indeed, proponents of the war often state that they do.
} 
The first section of this thesis will begin with a description of the neoconservative discourse and its main components. In this description, I will outline how war became part of the plan advocated by the discourse's architects. Chapter One will (a) outline the different components of the discourse, and (b) examine the way in which these components combined to create a specific vision and a strategy involving warfare. In this introductory chapter, I intend to show that the discourse's architects set as their raison d'être a vision that links the preservation and enhancement of American hegemony and security, with the creation of a secure, stable, and morally-driven world order. To create such an order, these architects promote a strategy of increased American influence around the world through all means necessary - diplomatic, economic, or military. This strategy, however, is only aimed at dealing with specific world actors. Architects of the discourse emphasize that America is not embarking on a quest for empire or world domination ${ }^{8}$. They only advocate increased American influence in the 'troubled' regions of the world. These regions threaten American security and freedom at home, and America's hegemonic position within the processes of globalization ${ }^{9}$.

Through this preliminary discussion of the discourse, two important features of it stand out: two-level thinking, and the tension of "isolationism-expansionism, ${ }^{10}$. Both of these features will be explained at the conclusion of Chapter One and further developed in Chapter Two. Briefly however, two-level thinking involves the idea that the

\footnotetext{
${ }^{8}$ In this paper, I will not enter the debate of whether or not the US is on a quest for empire. I believe that this debate moves the discussion of US involvement in Iraq and the Middle East into the larger issue of US involvement in other regions of the world. I am not interested in debating the latter point.

${ }^{9}$ While spreading freedom and democracy across the globe in its entirety is advocated, the discourse's architects understand that this is a difficult and enormous task. As a result, they advocate special US attention and focus on the regions which are of utmost importance to the US - i.e. ones that threaten American security. This point also involves the two-level thinking of the discourse - a point that will be discussed later in the paper when it is more appropriate.

${ }^{10}$ At the end of this introduction, I address the 'isolationist' school of thinking within the US, and how that school of thinking does not figure into my analysis.
} 
discourse's architects operate on two levels of planning: one strategic, the other moral. The important point here is that these levels are not in a symmetrical relationship, but rather the moral level holds a subordinate position to the strategic one. The second feature involves the idea that an important tension between two concepts operates within the discourse. Both isolationism and expansionism have an important influence on the neoconservative approach to foreign policy. Isolationism entails the idea that the US does not actively pursue the expansion of its power, influence, and involvement around the world for the sake of garnering more power and wealth. As I intend to show, this neoconservative movement does not seek to expand American power; it rather views the US as already residing in a position of unrivalled power, and it seeks to maintain that position with all of the benefits which come along with it - most notably, the benefit of maintaining and enhancing American sovereignty and security. It is this desire to enhance and maintain America's freedom from the world that represents the isolationist elements of the discourse.

Expansionism deals with the increased involvement and exertion of American power around certain regions of the world. The goal of this expansionism is to insert American-style political institutions in specific regions, and thus secure American interests and hegemony, as well as ensure American security. The most important characteristic of this expansionism is that this involvement, or intervention, is accompanied with the objective of quickly removing American power from the scene of intervention. Thus, expansionism entails both the increased exertion of American power 
in a region of interest, and the establishment of an indirect form of governance that is free of visible or heavy American influence and/or presence in the targeted region ${ }^{11}$.

Chapter Two will take a closer look at the tactic developed to address the 'Saddam question': the two-step plan of pre-emptive war and democratic political reconstruction. Since the architects of the discourse viewed the Middle East as the foremost troubled region, they advocated expanded US involvement in $\mathrm{it}^{12}$. They argued that war was the best tool available to carry out this expansion. The spread of American influence in the region, they argued, would have to be facilitated by a pre-emptive war. This step would be followed by a political project that would build a democratic Iraqi state, which will become an American ally in the future. This project would eventually allow America to withdraw from Iraq once the country is transformed from a threat to an ally of the US. This two-step plan brings into focus the two features of the discourse. I argue that the process of democratization is carried out to, first and foremost, achieve strategic goals for America rather than for its own moral good. Furthermore, I highlight how expansionism is limited to the war effort alone in this plan. Once the war is over, and the political reconstruction of Iraq underway, the US could pull put of Iraq and maintain a healthy distance from it. The last step of reconstruction is viewed as falling in line with the isolationist elements of this discourse. It represents the step whereby America can begin to decrease its involvement in Iraq once the threat is removed. To

\footnotetext{
${ }^{11}$ This is different from the old colonial regimes in both their direct and indirect forms of governance. This due to the fact that past colonial regimes (e.g. the British Empire) adopted either a direct or indirect form of governance only after establishing a colonial administrative structure that was run and directed by the colonial power (Furnivall 1956: 276). The US, on the other hand, seeks to transfer the task of governance to the native people of a foreign land as fast as possible. Their governance is indirect in the sense that the American-style political structures that are constituted in these foreign lands are meant to serve the interests of both America and the targeted region.

${ }^{12}$ Later in the paper, I will point out the differentiation made within the discourse between immediate and long-term threats. The Middle East falls into the category of an immediate threat.
} 
borrow Thomas Barnett's analogy, through this step, America can act as the midwife who delivers the baby, but does not inherit the parental rights to it (Barnett 2004: 358). In sum, this section will argue that this discourse promotes a tactic towards Iraq that is meant to serve America's strategic interests first and a moral cause second. Should the strategic interests be met through means other than the morally-driven method (i.e. the erection of a democratic Iraqi state), then Iraq's democratization process can and would be abandoned. This tactic also suggests that the two-step plan is both expansionist and isolationist. It is expansionist in the sense that it seeks to increase American influence in Iraq in particular and the Middle East in general. It is isolationist in the sense that its ultimate aim is to endow Americans with the freedom to choose their own domestic policies and national directions, and freedom from the world's problems and dangers. Therefore, the idea in this plan that war can be utilized as a mere step towards a political goal leads us to believe that a Clausewitzian view of war is what makes it theoretically possible.

The second section of the thesis will shift focus to the Clausewitzian view of war. This section will first outline the major paradox Karl Von Clausewitz faces with this view; and second will examine what this paradox means to this neoconservative approach. Chapter Three will rely heavily on the works of Foucault (2003) and Clausewitz $(1943)^{13}$. I will argue that the Clausewitzian view of war seems to neglect the possibility that war is much more than a violent means to a political end. War generates, in and of itself, effects and ends that are far too important to overlook. The ends produced

\footnotetext{
${ }^{13}$ I should mention that this is not considered the 'standard' translation of On War. The standard academic copy was translated by Michael Howard and Peter Paret in 1976, while the copy I am using was translated by O.J. Matthijs Jolles in 1943 (the reason for my choice is strictly resource-based). The only difference between the translations is in locating quotes, checking citations, etc. The contents of each translation are, for all intents and purposes, the same.
} 
through war generate an important connection between the first step of war and the political project that ensues from it. I will argue that the relations of domination born of war have to be accounted for in a discussion of the political project that follows war. This connection suggests that the main aim of the political project is the sustenance of the relations of domination born of war; as opposed to their suspension.

Chapter Four will deal with the impact of this paradox on the internationalists' plan. I will argue that the political reconstruction of Iraq cannot be viewed as a step towards American isolation from the region, but as one leading to an ever-expanding American role in it. The paradox, which Clausewitz himself could never come to terms with, suggests that the entire tactic produced through this discourse is expansionist in character. This brings up an important question: if the political reconstruction of Iraq indicates an expansionist tactic, why was it presented as one leading towards isolationism within the discourse ${ }^{14}$

For this question, I will re-examine two components of the discourse and the role their combination played in shaping the planning process: the language of 'good vs. evil', and 'American superiority'. I will argue that this combination has not only played a role in creating this expansionist tactic, but more importantly, it acted to nullify its expansionist character at the same time. This nullification is achieved through (a) the belief that American troops will be greeted as 'liberators' not 'occupiers' (i.e. we are good, Saddam's regime is evil - true for Iraqis as well as Americans), and (b) the idea that even a rudimentary form of democratic governance is an inherently superior system

\footnotetext{
${ }^{14}$ I am not claiming that the discourse's architects intentionally deceived the reader on this matter; I am simply curious to see how it was possible for them to overlook the paradox I am highlighting here.
} 
of governance (i.e. any system we present is superior to Saddam's regime) ${ }^{15}$. These two elements eliminate expansionism from the language of the planning process. It works as follows: since we Americans are good, and since what we are presenting to the Iraqis is unquestionably superior to what they already have, then this strategy is inherently marked by our generosity and our ability/duty to spread what is good and superior. Through this reasoning, expansionism turns into an act of giving ${ }^{16}$. With this in mind, I will reexamine the two strategic goals sought through this tactic: (1) the initiation of progress in the society of the 'Other', and (2) the removal of a security threat.

In Chapter Five, I conclude that the idea of initiating progress through warfare is not crucial to this plan's success or its degree of effectiveness in achieving the overriding (and most important) objective: the enhancement and sustenance of American sovereignty and security. Keeping in mind that political reconstruction is primarily characterized by the sustenance of relations of domination born of war, one can begin to see why this is so. When combined with the 'anything but Saddam' approach, the political reconstruction project can be seen to theoretically have a number of 'exit strategy' options available to it. Only one of these options is democratic governance (although it clearly remains the more favored option) ${ }^{17}$. A space is left within this plan where an American exit from the process of democratization, should it become too difficult to stay the course, can take place. In its place, a number of options are available where the political reconstruction can still sustain the relations of domination born of

\footnotetext{
${ }^{15}$ Even the anarchy ensuing the toppling of Saddam was greeted with joy by Defense Secretary Donald Rumsfeld. For him, it was the first sign of freedom from Saddam's rule, and was thus a positive sign. ${ }^{16}$ This feature of the discourse resembles the old colonial regimes, and more importantly, their methods of justifications. There are differences in this discourse however. This point will be examined at the end of Chapter Two, and once more in Chapter Four.

${ }^{17}$ The two other options associated with the US have historically been: 'divide and rule' and 'cut and run'.
} 
war. In short, the idea that this war was partly carried out to initiate the cultural, political, and economic progress of the foreign culture can be described as supplementary at best.

This brings me to the issue of security. While it is possible that the political reconstruction will successfully sustain the relations of domination born of war, I argue that a heavy price is paid for it. The underestimation of the effects of war, regardless of what political project ensues, has serious consequences for the isolationist elements sought after by the discourse's architects. Essentially, I argue that the discourse's architects have failed to see, or adequately deal with, the paradox that arises from the Clausewitzian view of war. While it is far too early to tell if this war will produce favorable results, be it democracy or security or both, one thing is certain: the ends internal to war will have important consequences not only on the direction this particular mission will take, but on the history of the forces involved, and on the kind of intercourse they will have in the future. For a movement in foreign policy thinking which claims that American security at home rests on a peaceful cross-cultural co-existence in the international sphere, this presents a serious questioning of its viability.

Before I proceed to section I, I provide a brief literature review, a discussion on methodology, and finally will clarify the relation (or lack thereof) between the isolationist school of thinking and my concept of isolationism.

\section{Literature Review:}

There are two strands of literature I will discuss here. The first strand involves the sociological literature surrounding war, which can be included under the heading of 'the sociology of war'. Most of this literature agrees that this field of study is not as well- 
developed, or established, as other spheres of sociological analysis ${ }^{18}$. Almost all of the important works which have been directed towards the development of this field begin with this premise (see Creighton \& Shaw (eds.) 1987 and Joas 2003 for influential texts making this point). Nevertheless, there are some promising cornerstones being laid out in the literature. In War and Modernity, Hans Joas (2003) provides us with perhaps the best overview of the field and its historical roots in sociological thinking. Joas argues that the many wars of history cannot be lumped together under one category, or reduced to one formula that attempts to explain them all (Joas 2003: 10). There are multiple types of wars, and my discussion is only concerned with wars that are fought between a strong and a weak side, and where cross-cultural forces are involved ${ }^{19}$. My analysis and conclusions should be viewed in this light. Secondly, Joas argues that a sociological analysis of war ought to reject the 'realism' argument. By this, he refers to the argument that essentially says: War is inevitable as it is a natural outcome of human power-politics. There is no other way to explain war, and therefore, we must simply try to make the best of it. This "Hobbesian power-political realism" constantly resurfaces in academic thinking (2003: 34), and sociological analysis can offer a counter-argument to it:

As a rule, we do not know what the interests of a state or a large-scale collective really are, who defines them, how this definition is arrived at, what conceptions of the world enter into it, whether power and security are conceived in an expansionist or defensive manner and whether these are mutually compatible in each individual case. For all its demonstrable resilience in the real world, power-political realism is by no means a simple reflection of reality, but rather something that arises from a programmatic de-moralization and an empirically problematic abstraction from the normative and interpretive character of reality. (2003: 34)

\footnotetext{
${ }^{18}$ As a result of this, the field has not quite developed different schools of thinking within it. It rather involves different attempts at identifying its boundaries and its historical roots.

${ }^{19}$ This in opposition to Hardt \& Negri's assertion that we must view the wars of our time (civil and interstate) as part of "a general global state of war" (Hardt \& Negri 2004: 5; original emphasis) that encompasses them all.
} 
The questions posed above are essentially the ones I am dealing with here (with the exception of the very first one $)^{20}$. In addressing these questions, my approach does not lose sight of the latter part of Joas's quote. This means that while I 'blindly' accept the arguments the neo-conservative discourse puts forth, it does not mean that I view these arguments as the ones indicative of 'reality'. I simply accept them in order to analyze them ${ }^{21}$. Finally, and most importantly, is a point which Joas only briefly raises as a question: "how are we to overcome an instrumental understanding of violence without contributing to a broadening of the concept to the point where all human relations appear to be permeated by violence and all social order posited by it?" (2003:42) Rejecting this instrumental view of war is precisely the main theoretical argument of this thesis, and to be truthful, I am not sure whether or not I will be able to avoid the outcome stated above. My attempt to do so largely depends on my narrowing down of the discussion to the Iraq War alone. I realize, however, that while this may suffice for now, it does not directly or adequately deal with Joas' important question.

The second strand of literature involves some of the academic analyses of the neo-conservative discourse in question. Michael Mann (2003) has perhaps produced the best opposition to this discourse. In Incoherent Empire, he argues that the empirical and ideological arguments advanced by these neoconservatives - or as he refers to them, the "chicken-hawks" (Mann 2003: 8) 22 -are either flawed or completely misguided. For Mann, the American Empire is not the benevolent force in the world the 'chicken-hawks'

\footnotetext{
${ }^{20}$ My method will essentially accept what the neoconservative discourse puts forth as 'national interests'. From this basis, I engage in a critical analysis of these interests (i.e. the 'isolationism-expansionism' tension). Further discussion on my method will be presented shortly.

${ }^{21}$ This point will be further developed in my discussion of the second strand of literature and in the methodology section.

${ }^{22}$ This term refers to the fact that the main intellectual and political proponents of the Iraq War have never fought in a war.
} 
make it out to be. It rather is an empire whose capacities (economic, political, and ideological) cannot match its aims of indirect rule over foreign lands or its ability to ensure stability in the world (2003: 13-15). In short, Mann presents his own empirical and ideological arguments, and attempts to undermine the neoconservatives through them. Numerous others follow this line of academic analysis ${ }^{23}$ (Chomsky 2003; Dominicè 2003; Dower 2003; Hartung \& Donnelley 2003; Jervis 2003; Klare 2003; Preuss 2003) ${ }^{24}$.

Others have had a different kind of objection to this discourse. Thomas Barnett (2004), Robert Art (2003), and Niall Ferguson (2004) argue that what is missing from the current US approach is a coherent grand strategy. They support the war effort in Iraq, but are concerned that the architects of this discourse have failed to accompany it with a grand strategy that will sustain and enhance the achievements of the $\operatorname{war}^{25}$. Once again, what is opposed, or is presented as lacking, are the empirical and ideological arguments of the discourse. This opposition is often based on the differing empirical and ideological arguments presented by these authors. To sum up, whether for or against the war, academic analyses of this discourse debate with it on the basis of the empirical and ideological arguments put forth by the analyst. While insightful, provocative, and instructive, such a mode of analysis will not be conducted in this thesis. Rather than analysing this discourse on the basis of my own opposing discourse complete with its empirical figures and ideological assumptions, I will examine it from within. The construction of my argument will be solely based on an exploration, disentanglement, and

\footnotetext{
${ }^{23}$ The method of analyses utilized by these authors is more important for my purposes than their arguments. Since their methods take an approach similar to Mann's, I will not delve into their arguments in this paper.

24 Just to name a few.

${ }^{25}$ It is questionable, and unclear, whether or not Art (2003) supports the Iraq War. The grand strategy he advocates, however, is congruent with many aspects of the neoconservative rationale for war in Iraq.
} 
critical reflection of the discourse within its own boundaries. Such a task has not been undertaken in this field of study ${ }^{26}$.

\section{Methodology:}

The methodology of this paper takes its roots in Foucault's work on discourse analysis. In The Archaeology of Knowledge, Foucault (1972) outlines a number of principles and guidelines for the analysis of discourse, some of which are central to my analysis. Foucault defines discourse as a

... group of statements [which] belong to the same discursive formation; it does not form a rhetorical or formal unity, endlessly repeatable, whose appearance or use in history might be indicated (and, if necessary, explained); it is made up of a limited number of statements for which a group of conditions of existence can be defined. (Foucault 1972: 117)

Thus, the unity of the discourse is not the 'self-evident reality' historians have made it out to be (1972: 79). Rather, it is the task of the analyst to determine this unity by defining the "rules of formation" that govern the appearance of a discourse in its specificity. This process occurs in a space Foucault refers to as "discursive formations" (1972: 38). Basically, this space consists of a number of components that produce and re-produce a specific discourse across time. While each of these components operates in all of the different texts of this discourse, they are given greater or lesser attention in each depending on the specialty of the author involved. The connection between the texts lies in the fact that each author is dependent on each of these components in one way or another, sometimes explicitly, but mostly implicitly. For instance, when Kagan \& Kristol (2000) argue for a morally-driven foreign policy towards the Middle-East as a matter of

\footnotetext{
${ }^{26}$ It is because of this that the literature review may appear somewhat more brief than normal.
} 
strategic interests, they are very much dependant on the need to move away from the moral relativism that Frum \& Perle (2003) discuss more deeply. So, the important connection is that they all see the world in 'black and white' terms, and understand the connection between moral thinking and strategic interests. The fact that each text focuses on different issues only strengthens the neoconservative internationalist movement.

In this study, then, discourse will be viewed as containing a set of components that shape it, determining its limitations and boundaries. The repeated appearance of these components across the various books and articles analysed, indicates a "discursive regularity" (Foucault 1972: 21-76), where correlations or themes can be found between the different texts. These components will thus provide the crux of my description; as opposed to the individual texts themselves. Different texts will be used to help describe different components, but the relations between these components operate in all of these texts; hence their unity. To sum up, the naming of this collection of books and articles as a neoconservative internationalist discourse rests on the idea that the same rules of formation are operating within all of them. These rules consist of the relations that can be observed between the different components of the discourse across the different texts.

There remains one methodological question to deal with here: on what grounds do I make the assumption that this discourse is indeed pertinent to the analysis of the Iraq War? There are three reasons for my choice of these texts in particular and this discourse in general. The first is the close association of the authors of these texts to high-ranking positions of decision-making in the US. For instance, Paul Wolfowitz currently serves as Deputy Secretary of Defence in the Bush administration, Douglas Feith currently serves as Undersecretary of Defence for Policy. Other figures such as Richard Perle, Robert 
Kagan, and William Kristol have all written policy articles found on "The Project for the New American Century" (PNAC) website ${ }^{27}$; many of which were sent to the office of President William J. Clinton and other important policy-makers during the late 1990s. Most of these statements were signed by important political figures such as current Secretary of Defence Donald Rumsfeld, and current Vice-President Dick Cheney ${ }^{28}$. The second reason for choosing these texts is the reflection of their main ideas and components in official US policy statements. I will not go into detail here about what these similarities are. Once I discuss the main components of this discourse, it should become clear that they correspond closely to official American policy (namely The National Security Strategy of the United States of America document), as well as presidential speeches ${ }^{29}$. The third and main proof that these texts are pertinent to the analysis of the Iraq War is simple: the fact that the US did indeed carry out a policy of war against Iraq. This is the important glue that holds all of these different texts together: they unanimously initiated, advocated, and supported the war against Saddam and the invasion of Iraq. These three reasons guided my choice of the texts, and helped me determine what to include and exclude from the analysis.

\footnotetext{
${ }^{27}$ All three have, at one point, held positions within the administrations of Ronald Reagan and George $\mathrm{H}$. Bush.

${ }^{28}$ It is important to note that these connections are not indicative of some kind of conspiracy between the architects of this discourse and the positions of power. Architects and supporters of the discourse (when not in position of power, e.g. Perle or Wolflowitz) are frank about their influence on American foreign policy, and do not consider this influence as representative of a secret 'coup' in Washington (see Kaplan \& Kristol 2003: $65-75$ for a historical overview of this rising influence). They simply believe that they presented the Bush administration with the best ideas for dealing with the threat of terrorism and the dangers of tyrannies: "we suspect that the average Republican primary voter ... thinks about foreign policy almost exactly as Washington's hawks do: that enemies cannot be palliated and must be fought. That sympathy of views, not conspiracy, explains why the advocates of a strong policy have prevailed since 9/11. The American public instinctively senses that in a dangerous world the toughest line is the safest line." (Frum \& Perle 2003: 191).

${ }^{29}$ Throughout my discussion of the discourse, I will alert the reader to this connection by referring to the specific official documentations and/or speeches that resemble, and are congruent with, the ideas of the discourse. This will only be done for specific important ideas because of space and time purposes.
} 


\section{Isolationism and the internationalist school:}

Foreign affairs debates are often fought between three schools of thinking in the US: isolationists, internationalists, and realists ${ }^{30}$. Moreover, those who fall into one of these schools are divided into those belonging to either the political Left or the political Right. This leaves six different schools of thinking which advocate different approaches to foreign affairs (Ceaser 2000: 25-43). As already mentioned, the intellectuals analyzed in this paper belong to the internationalists of the Right. They, of course, are vehemently opposed to the isolationist approach and its advocates; yet I am using the term isolationist to describe parts of their discourse. To avoid confusion, I wish to clarify that I am not asserting that these intellectuals are isolationists turned internationalists, or isolationists promoting their cause under the guise of internationalism. I simply have not found a better concept to describe the discourse of these internationalists other than isolationism. In short, my concept of isolationism should be considered only within the context of the internationalist school. In other words, I will discuss this internationalist school in isolation of all the other ones.

\footnotetext{
${ }^{30}$ This does not include the Marxist or other schools of thinking. I have chosen to only mention those schools which are often highlighted by the neoconservative internationalists, and with which they primarily debate.
} 


\section{SECTION ONE}




\section{Chapter One}

\section{'An Exploration of the Internationalist NeoConservative Discourse'}

This chapter will discuss the five major components which make up the neoconservative discourse: 'good vs. evil', 'American superiority', 'American security', 'American hegemony', and 'American leadership'. Once each component is discussed, attention shifts to the vision and strategy these components combine to create. It should be kept in mind that the following account will only focus on the shared elements in this discourse. While each account I provide is derived from different texts across the neoconservative discourse (with the exception of the first component ${ }^{1}$ ), I rely more heavily on specific texts for each component.

These texts are: (1) 'Good vs. evil' - Frum \& Perle (2003), (2) 'American superiority' - Kaplan \& Kristol (2003), Gerecht (2000, 2001), (3) ‘American security Wolfowitz (2000), Kagan \& Kristol (2000), Kaplan \& Kristol (2003), (4) ‘American hegemony' - Kagan \& Kristol (2000), Kagan D. (2000), Kagan R. (2003), and (5) ‘American leadership' - Kaplan \& Kristol (2003), Kagan R. (2003).

\section{The Five Components}

\section{The Battle between 'Good' and 'Evil':}

The collapse of the twin towers in New York City on September 11, 2001 was a loud and sobering wake-up call for all Americans. Two messages came with the attacks.

\footnotetext{
${ }^{1}$ Kaplan \& Kristol (2003) address this component as well, but not in the depth that Frum \& Perle (2003) do -i.e. they do not add anything new. That is why I did not cite them in this component.
} 
The first was that enemies abroad could reach American soil and inflict enormous damage upon American society. This was a frightening and dangerous development - a truly new experience for most Americans. Not since the bombing of Pearl Harbor had Americans experienced such an attack on home soil. The second, and more important message, was that evil had not been eradicated from existence with the fall of the Soviet Union. It has rather re-emerged in a new and dangerous form. This new evil was not as clearly definable as America's past evil enemies, for it did not come from any one particular state. It rather consisted of small, mobile units that transcend the borders of sovereign states. More importantly, this evil aimed to strike at the very core of civilization: the civil and open society. What was terrifying about $9 / 11$ was that the attackers managed to strike civil society through its openness. The hijackers had shown a daunting ability to exploit every weakness of American society to carry out their attacks². Lenient and incompetent domestic policies, which allowed suspected terrorists relative freedom of movement and communication, along with soft foreign policies, which did not respond to terrorist attacks firmly and wholeheartedly, contributed to the success of the attacks on 9/11 (Frum \& Perle 2003: 62) ${ }^{3}$. American complacency, and more importantly, the era of 'moral relativism' had shown loud and clear what their consequences were ${ }^{4}$.

The events of that day reminded Americans that not all people deserve the civil treatment an open society provides its subjects. $9 / 11$ had definitively shown the world

\footnotetext{
${ }^{2}$ Or more properly, of Western society. Some of the hijackers conducted a considerable amount of their planning and training in Germany (The 9/11 Commission Report 2004: 160-173).

${ }^{3}$ The 1993 attack on the World Trade Center and the 2000 attack on the USS Cole are two examples of such attacks.

${ }^{4}$ This detestation of moral relativism runs through neoconservative discourse across its various spheres of interest (Zagacki 1996: 182). For this strand of the discourse, see (Kaplan \& Kristol 2003: 64).
} 
that humanity was still divided into two camps: good and evil. More importantly, it had crystallized for the world what was good and what was evil. In this era, terrorism had shown itself to be "the great evil of our time." (2003: 9) This evil does not reside in the hearts of a specific race, culture, religion, or nationality. It resides in terrorism and its proponents, wherever they may be and whoever they are. In the war on terror, the enemy is not the Arab Muslim world in its entirety; it rather is a small faction of it. Hence, this is not a 'clash of civilizations', a war between East and West, or between Christianity and Islam; it is a clash of ideologies. On the one side lay the ideology of freedom, liberty, and democracy, and on the other lay the ideology of hate, destruction, and tyranny.

While this evil ideology only represents a small faction of the Arab Muslim world, it can not be underestimated, for its ultimate goal is to spread across the entire Islamic world:

The terrorists are cruel, but they are not aimless. Their actions have a purpose. They are trying to rally the Muslim world to jihad against the planet's only superpower and the principal and most visible obstacle to their ambitions. They commit terror to persuade their potential followers that their cause is not hopeless, that jihad can destroy American power. (2003: 9)

This is an expansionist ideology, and its aims are nothing short of "world domination" (2003: 42-43). It is an ideology that "perverts the language of justice and equality to justify oppression and murder", and its expansion feeds on "the injured pride of oncemighty nations." (2003: 43) America had to reach the potential followers of this terrorist movement before the ideology of hate did. Evil's momentum in the region could not be allowed to proceed unopposed. If this war on terror was to be won, it had to be won in the Arab Muslim world. Halting the expansion of this ideology therefore meant bringing the forces of good to a direct confrontation with the forces of evil for all in the region to 
witness. In other words, an alternative to this evil ideology had to be presented to the Arab world on Arab soil. The only question left was where would this occur?

The populations this evil preys on inhabit states that are either too weak or are unwilling to deal with terrorism (2003: 118). Since vital US interests were at stake in this war, America had to intervene in these states and crush terrorism for them and/or in spite of them. The US, however, had to be careful in its approach towards these weak states. If the state simply lacked the resources to fight terrorism, the US would simply aid them tactically, strategically, and monetarily (2003: 118-19). If these states sponsored terrorism, or colluded with terrorists, then a hard-line approach was necessary for two reasons (2003: 119). First, it was necessary because it would lead to the destruction of terrorist networks and their infrastructure (as was the case in Afghanistan). Secondly, it was necessary so that the clash of ideologies could be fought, and ultimately won. The latter point is where Saddam Hussein and his tyrannical regime joined the war on terror. Iraq was the ideal theatre for an ideological confrontation between good and evil. The destruction of Saddam's tyrannical regime and the establishment of a democratic Iraq in its place would show the Arab world the ideological alternative to terrorism. The presentation of a living example of such an ideology in a democratic Iraq would make this possibility a reality for Muslim Arabs everywhere (2003: 163-164). In the absence of such an example, evil would have simply consumed the region - why? Because if Saddam were to beat the sanctions and remain in power, the terrorists would have been "emboldened and inspired" (2003: 28). What Arabs may have perceived in Saddam as a courageous defiance to the US had to be presented to Arabs for what it really was: Arab fatalism (2003: 32-33). There was no middle ground here: Arabs had to choose between 
an ideology of hate that preyed on their weaknesses, and an ideology of freedom that gave them a chance for a re-birth (2003: 165-168).

In this war, Americans must always bear in mind that this battle of good vs. evil is not one to be settled through negotiations:

Americans are [not] fighting this evil to minimize it or to manage it. We believe they are fighting to win - to end this evil before it kills again and on a genocidal scale. There is no middle way for Americans: it is victory or holocaust. (2003: 9)

This means that any attempt to understand why these terrorists hate America is meaningless. In this battle, there is no need to know why the enemy hates 'us'. It is 'they' who have the problem, and 'we' should not apologize for who we are. Even though the US has committed its mistakes in the region, these mistakes could not have given rise to "a hatred as all-consuming and self-destructive as the hatred encountered in radical Islam" (2003: 48). This hatred has its roots in the feelings of Arab inadequacy and failure in relation to America and the West. The lack of Muslim Arab dominance (social, political, and economic) in the world led to an implosion of their societies which, following World War Two (WWII), simply "plunged into an abyss of cruelty and terror." (2003: 55) The US could not be blamed for this turn of events. The situation in the region was already dire when its strategic importance during the Cold War forced increased American involvement in $\mathrm{it}^{5}$. This pulled the US "deeper and deeper into the region's vortex of paranoia and hatred." (2003: 56) Sprung from the wounds of an injured pride,

\footnotetext{
${ }^{5}$ This strategic importance involved both the fight against Communism, as well as control over oil. While the former point is no longer applicable to American strategic goals today, the latter remains immensely important. As reported in The Guardian on June 4, 2003, Wolfowitz admits: "Let's look at it simply. The most important difference between North Korea and Iraq is that economically, we just had no choice in Iraq. The country swims on a sea of oil." (Quoted in Žižek 2004: 5)
} 
this hatred transformed itself into violent acts of destruction aimed at restoring the dignity and self-respect of Muslim Arabs (2003: 58):

Religious extremists and secular militants; Sunnis and Shiites; communists and fascists - in the Middle East, these categories blend into one another. All gush from the same enormous reservoir of combustible rage. And all have the same target: the United States. (2003: 59-60)

This is a hatred that is sustained and continuously reborn in a tyrannical political atmosphere akin to a "swamp" $(2003: 161)^{6}$. It is these tyrannies that lie at the heart of the problem, not the democracies of the West. Since the roots of the problem lay in the camp of evil, there was no need for America "to apologize to anyone for its culture" (2003: 148). The battle lines in this war are unequivocally clear: you are either on the civilized side of good, or on the terrorist side of evil. An apologetic approach could not have conveyed this important message. Moreover, such an approach would only invigorate the terrorists and send the following message to the Arab world: your acts of violence have given you strength in the sense that you now have the attention of the West; the West is even somewhat afraid of you - your pride could thus be effectively restored through violence (2003: 148-150).

In this war, such a compromise or an appeasement of evil would have been disastrous (2003: 41). Since 9/11, American strength and commitment was needed more than ever. This non-apologetic hard-line approach would convince many Muslim Arabs around the world to begin the much needed political, social, and economic transformations of the Arab world. Muslims alone can conclusively win this war of ideologies, but only the US can make that victory possible (2003: 152; 278).

\footnotetext{
${ }^{6}$ See appendix A for a longer and more detailed description of this political atmosphere. This piece makes clear what this view of the Arab world entails.
} 
In this era, "terrorism remains the great evil of our time, and the war against this evil, our generation's great cause." (2003: 9) At stake, lay the very future of the world. The US had to compellingly show that the future does not belong to America's enemies; that "terrorism was not winning" and that America had the will, strength, and resolve to fight this war and win it (2003: 28).

\section{American Superiority:}

In the war on terror, the US could not afford modesty - the various strengths of America's political, economic, and military institutions had to be used to their full capacity $^{7}$. When these institutions operate in a cohesive manner, nothing can defeat or even challenge the US. Moral clarity had to be accompanied with the use of superior American power to ensure that 'good' prevailed. The use of power here comprises the spread of superior American-style political institutions and the belief in America's ability to accomplish this feat.

First is the confidence in America's political institutions. This confidence stems directly from the belief in "American Exceptionalism" - a belief in the uniqueness and the virtue of the American political system that, when translated into foreign policy terms, offers the United States as a model for the world." (Kaplan \& Kristol 2003: 64). This is distinct from the "logic of cultural relativism", which only encourages "a deepseated reluctance to judge others and [a] lingering skepticism about America's founding

\footnotetext{
${ }^{7}$ The focus in this discourse is primarily on political and military issues. Economic strength is primarily brought up when a case for stronger military and defense funding is being advocated (see Kagan F. 2000: 241-65 for an example). It is important to note here, though, that this approach rests on the idea that, in the post-Cold War era, global economic interdependence is well under way, and heading into a direction that is favorable to American economic interests. Thus, the aim within the discourse is to accompany this economic project with a political one (Kagan D. 2000: 337-40).
} 
ideals" (2003: 64). The internationalists embrace America's founding ideals, and view them as a source of strength and confidence, not as a source of discomfort and hindrance.

Americans should not doubt that what America is offering the Middle East is superior to their current way of life. In the case of Iraq, Americans had to avoid "moral evasion" (2003: 94), and face the facts: Saddam Hussein "is at once a tyrant, an aggressor and, in his own avowed objectives, a threat to civilization." (2003: 3) The democratic political institutions of America were clearly superior to Saddam's tyranny in three ways. First, democracies simply never wage war against each other (2003: 104). Second, they provide economic, religious, and individual freedoms that no other political system can (2003: 95). Finally, they are universally applicable across time and space (2003: 109111). The spread of democracy is thus a positive undertaking. Over time, it will prove beneficial to Iraqis, Americans, and the world. In the words of historian John Lewis Gaddis,

The intersection of radicalism with technology the world witnessed on that terrible morning means that the persistence of authoritarianism anywhere can breed resentments that can provoke terrorism that can do us grievous harm. There is a compellingly realistic reason now to complete the idealistic task Woodrow Wilson began more than eight decades ago: the world must be safe for democracy, because otherwise democracy will not be safe in the world. (Quoted in Kaplan \& Kristol 2003: 102)

Second is the belief in America's ability to spread American-style political institutions. While diplomacy and multilateral institutions (such as the IMF, the World Bank, and the United Nations) can aid in this task, the spread of democracy has to be backed by American power, and that includes the use of force (Kaplan \& Kristol 2003: 113). This belief in America's military capabilities has its roots in a 'new revolution in military affairs' (RMA) introduced in the mid 1990s by Harlan Ullman (1996, 1998 et 
al) ${ }^{8}$. In this work, a new strategy - Rapid Dominance (RD) ${ }^{9}-$ was developed to deal with the new dangers and threats of the post-Cold War era. RD's main advantage is the ability to strike an enemy with great speed and lethality. Its ultimate aim is to provide policymakers with maximal political flexibility and leverage (Ullman \& Wade 1998: 1-2). It will make 'rogue states' think twice before opposing American interests, particularly because $\mathrm{RD}$ will enter the thought process of their leaders and affect their will and that of their people (1998: 78). In short, with the ability to strike hard and fast, the US could utilize its superior military power to impose its will upon its enemy with relative ease and within a short period of time.

When it came to the Middle East, this new military capability had to be used. This is a region that is most impressed with military power. Its militants and political leaders only "understand strength and have only contempt for weakness." (PNAC website: Perle in Schmitt Feb. 2003) If the period following 9/11 was allowed to pass without the maximum exertion of American military power, then the region would have perceived America as weak:

Without a successful war to remove Saddam, we will return to the pre-9/11 pattern of timidity that Osama bin Laden so effectively underscored in his writings and speeches. In the eyes of the young men who live with the purpose and promise conferred by the hope of martyrdom, we will have shown that Osama was right - that indeed we are no longer 'the strongest horse.' And these young men will ... brutally reveal to us that an attempt to prosecute a 'global counterterrorist campaign in the absence of awe at American power is bound to fail. (PNAC website: Gerecht Oct. 2002)

\footnotetext{
${ }^{8}$ Although this group of military strategists and theorists are not part of the neoconservative movement I am describing, their work is of immense importance to understanding it. The military strategy developed by Ullman (and others) is indeed the one eventually advocated by the neoconservatives (Kagan R. 2003: 92), pushed through by Donald Rumsfeld (Woodward 2004: 102), and the one finally adopted by the Bush administration.

${ }^{9}$ I provide a more detailed discussion of this strategy in Chapter Two.
} 
This could not be allowed to pass for "'weakness is provocative': that's one of Donald Rumsfeld's famous rules, and a decade of weakness in the Middle East had proved Rumsfeld right." (Frum \& Perle 2003: 16) Even before 9/11, this lesson was being taught to American policy-makers. The soft policies of the 1990s towards Saddam produced devastating results for American interests. When it became clear to Saddam and the people of the Middle East that America was not prepared to go to war with him, a set of inevitable consequences unraveled. These included

... the slow-motion evisceration of the United Nations weapons inspections; the abandonment of the U.S.-supported opposition group the Iraqi National Congress; Washington's embrace of the lame coup attempted by the opposition group Iraqi National Accord; the collapse of the sanctions regime; the revival of anti-Americanism in the 'Arab street'; the resurrection of Saddam Hussein as the great defender of the Muslim Middle East ... and the increasingly pro-Iraqi attitudes of Paris, Moscow, and Beijing (PNAC website: Gerecht May 2001).

America had the military capabilities to avoid such dire consequences ${ }^{10}$. It was the political will that was missing.

In dealing with a region whose leaders and populace were most accustomed to the language of force - to "ruthless power politics" (PNAC website: Gerecht May 2001) policy-makers could not afford timidity. Only through the application of its military power could America impose its superior ideals on a region badly in need of resuscitation - "Triumphant for a thousand years, Muslims have now witnessed three-hundred years of unrelenting defeat. Unfortunately, the Arab Middle East easily takes solace in a ruthless despot who can intimidate America ... If we are to protect ourselves and our friends in

\footnotetext{
${ }^{10}$ In a letter sent to the Speaker of the House - Newt Gingrich, and the Senate Majority Leader - Trent Lott, a set of strategic consequences were laid out that capture the importance of the list presented above by Gerecht. The main one being: the loss of American credibility and the expansion of Saddam's power in the region. This letter was signed by a number of people including: Richard Perle, Donald Rumsfeld, and Paul Wolfowitz (PNAC website: May 1998).
} 
the Middle East, who are many, we have to rebuild the awe which we have lost through nearly a decade of retreat." ${ }^{\text {"11 }}$ (PNAC website: Gerecht May 2001; emphasis added) The failures of past US administrations to act decisively against Saddam have made him look stronger than the US in the eyes of the Arab world (Frum \& Perle 2003: 16-20). As Paul Wolfowitz observed,

American declarations in 1990 that we took no position on the disputed border between Iraq and Kuwait may have encouraged Saddam Hussein to think that he could attack with impunity ... One might observe a persistent source of misunderstanding between democracies, which look constantly for pragmatic solutions to resolve concrete problems in isolation, and more ruthless leaders, whose real goal is to change the existing power relationship and who misinterpret a democracy's evident desire to resolve a dispute peacefully as a sign of weakness. (Wolfowitz 2000: 322)

This had to change, and this change which began with moral clarity, had to be complemented with the embrace and utilization of American superiority. America had to become more forceful in the world. The future rested on it (PNAC website: Schmitt March 2003).

The maintenance of a decent and hospitable international order requires continued American leadership in resisting, and where possible undermining, aggressive dictators and hostile ideologies; in supporting American interests and liberal democratic principles; and in providing assistance to those struggling against the more extreme manifestations of human evil. If America refrains from shaping this order, we can be sure that others will shape it in ways that reflect neither our interests nor our values ... A humane future, then, will require an American foreign policy that is unapologetic, idealistic, assertive, and well funded. (Kaplan \& Kristol 2003: 120; emphasis added)

\footnotetext{
${ }^{11}$ Earlier in the peace, Gerecht describes this awe with the Arabic term 'hayba', meaning to cause fear from an all-overpowering and awe-inspiring force.
} 


\section{American Security:}

The most solemn duty of any American leadership is the preservation of American security at home and abroad. Prior to $9 / 11$, Americans mistakenly felt invulnerable on domestic soil. After the attacks of that day, Americans were forced to rethink and re-conceptualize their security. Tougher domestic policies were introduced with the passing of the 'Patriot Act', and a new federal department - 'The Department of Homeland Security' - was erected to directly deal with the issue of domestic security. These domestic changes - or the defensive reaction to $9 / 11$ - were significant, but they were not enough on their own. In the age of terror, the preservation of homeland security rested more and more on the offensive act abroad.

The new security environment of the $21^{\text {st }}$ century began to form well before $9 / 11$. During the 1990s, civil wars broke out across different regions of the globe, developing various forms of unrest and instability with detrimental effects on America's strategic interests. The response of the US to most of these disturbances seemed to be: "we have no business intervening in conflicts among people we do not understand, where 'we have no dog in the fight'." (Wolfowitz 2000: 313) This response was imprudent and shortsighted. With all of the uncertainty surrounding this era, one fact was certain - the US was the world's sole superpower, and it was thus its duty to act like one:

The United States is not Switzerland ... which can afford to isolate itself from a world over which it has little control and focus simply on how to make money and enjoy its life in peace. With so great a capacity to influence events comes a requirement to figure out how best to use that capacity to shape the future. $(2000: 314)$ 
Being the world's sole superpower did not mean that there were no more threats to contend with; it simply meant there were new ones. The first step towards sound policy was to understand these threats.

Understanding such threats means contextualizing them within the proper grand strategy concerns and goals of American foreign policy. In grand strategy terms, the main concern or national security issue facing America in the $21^{\text {st }}$ century is the emergence of a hostile superpower that would seriously challenge US hegemony. The main goal is to stop such a power from emerging in the first place, or to allow it to rise in an international environment that would be conducive to an American victory over any such challenge. This idea first surfaced in 1992, when Paul Wolfowitz outlined it in a draft memo from his office in the Pentagon. It subsequently formed the basis for the Regional Defense Strategy issued by, then Secretary of Defense, Dick Cheney. The core idea of this strategy

... suggested that a 'dominant consideration' in U.S. defense strategy should be 'to prevent any hostile power from dominating a region whose resources would, under consolidated control, be sufficient to generate global power.' Those regions were specified as including Western Europe, East Asia, the territory of the former Soviet Union and Southwest Asia. (2000: 309) ${ }^{12}$

While it is true that the post-Cold War era seems to have eradicated major philosophical confrontations, and while it seems that liberal democracy has taken root as the sole legitimate philosophical force in the world ${ }^{13}$, "it would be a mistake to assume

\footnotetext{
${ }^{12}$ The absence of the Middle East from this list is of immense importance. This stems from the pre-9/11 (early 1990s) belief that the rogue regimes of the region are threatening to American security only in so far as they represent potential allies to an emergent hostile superpower (from outside the region), where they would supply such a power with the necessary resources (e.g. oil) for a confrontation with the US and its allies (this is discussed on pp. 30-33). This is one of the few, yet crucial, points in which this discourse intersects with Samuel Huntington's (1996) famous thesis.

${ }^{13}$ This does not mean that communism is dead; it simply means that it has lost its "world-revolutionary spirit" (Wolfowitz 2000: 318). While some anxiety towards the rising popularity of Islamic rule exists, it is
} 
that the emergence of new powers in the world, particularly China, will automatically take a more peaceful course than the emergence of other great powers in the past." (2000: 318; emphasis added) China represents the greatest threat to American hegemony in the $21^{\text {st }}$ century ${ }^{14}$ (Kagan R. 2003: 93). In dealing with China and other potential threats, America must strengthen its alliance with liberal-democracies around the world (PNAC website: Schmitt July 2003) ${ }^{15}$. This serves both to protect the security of allied nations, and more importantly, to bring them prosperity (economic and political). Two important positives arise from this: (1) with the strength of an alliance security structure, it "demonstrates that problems are better solved within that alliance structure" (Wolfowitz 2000: 333), and (2) with prosperity for those who are within this alliance, it makes "the status quo attractive to all comers" (2000:333). Simply put, the best way to deal with the uncertainties of an emergent China, or any other potential threat for that matter, is to shape the future - to either eliminate the confrontation altogether by absorbing countries like China into an alliance structure, or to let the confrontation transpire in an atmosphere conducive to an American victory (2000: 314-316; Kagan \& Kristol 2000: 12).

With this grand strategy in mind, foreign policies should thus focus on how ... to minimize the likelihood that we will be forced to engage in another major (hot or cold) war in the future and, if such a conflict can not be averted, to best position ourselves to wage it ... In general, a threat of this magnitude will require a major power that seeks to upset the international

\footnotetext{
not considered a serious revolutionary threat as of yet. Wolfowitz sums this up here, "It is only in the Muslim world that a revolutionary notion of societal organization has philosophical roots, and that notion, at least for now, is very much on the defensive in Iran, its own home base." (2000:318)

${ }^{14}$ There are numerous approaches advocated to deal with China. Since this is not the focal point of my research, I will not delve into the matter. Suffice it to say, the overwhelming consensus is that China represents a power to be dealt with, or at the very least, watched carefully.

${ }^{15}$ This is a point that was continuously stressed in face of unilateral allegations (a point to be discussed later in the paper). While testifying before the Senate Foreign Relations Committee, William Kristol asserts that "we continue to believe that the goal of maintaining peace and prosperity in the world is best accomplished by working with our democratic allies both to protect existing democracies and, where necessary or possible, to expand liberty's reach to other nations." (PNAC website: in Schmitt July 2003)
} 
status quo, and troubled waters in which it can fish. (Wolfowitz 2000: 333; emphasis added) ${ }^{16}$

The elimination of these prerequisites, or at the very least the reduction of their potential potency, should form the basis for immediate foreign policy decisions ${ }^{17}$. The US, therefore, had to effectively deal with "rogue states and minor disturbers of the international order." (2000: 333) The elimination of such states would play a major role in depriving a future superpower of a potential ally: "A country determined to mount a major attack on the status quo would find a country like Iraq a willing ally and a source of leverage against the US and its allies." (2000: 333-34) Therefore, the direct and pressing need of foreign policy was to deal with countries like Iraq ${ }^{18}$. In dealing with it, the goal ought not be co-existence and/or developing better relations with Saddam ${ }^{19}$; the goal ought to be the transformation of Iraq - to rid the region and the world of Saddam's regime (Kagan \& Kristol 2000: 20).

Unfortunately, the 1990s policies towards Iraq consisted of appeasement and containment policies that could only produce one result: create a world "where everyone has to 'do business' with Saddam and his weapons of mass destruction" (PNAC website:

\footnotetext{
${ }^{16}$ China is often cited as the most likely candidate to become this hostile superpower. To a much lesser extent, there exists some fear about a resurgent Russia, or an emergent Iran.

${ }^{17}$ It is important to note that this idea was indeed put into practice, under the leadership of Paul Wolfowitz, twice before it made its appearance in an official strategic document in 1992: "Paul Wolfowtiz ... who as assistant secretary of state for East Asia in the Reagan administration was the crucial figure in forcing from power two Pacific Rim dictators: Ferdinand Marcos of the Philippines in 1985 and Chun Doo Hwan of South Korea in 1986." (Frum \& Perle 2003: 159-60)

${ }^{18}$ This point is reiterated by Kaplan \& Kristol (2003) in their evaluation of the Iraq War: “... members of the Bush team recognize that the present era offers both crisis and opportunity. In their view, the United States must pursue two goals at once: first, the promotion of a world order conducive to American interests and principles; and second, a defense against the most immediate and menacing obstacle to achieving that order." (Kaplan \& Kristol 2003: 118) This shows how this idea, which emerged in the mid 1980s - early 1990 s, was alive and well in 2003.

${ }^{19}$ That would be morally repugnant and strategically counterproductive. Saddam's interest in regional domination (to be discussed shortly) was irreconcilably opposed to one of America's vital national interests: to be "at once a European power, an Asian power, a Middle Eastern power and, of course, a Western Hemispheric power." (Kagan \& Kristol 2000: 16)
} 
Kagan \& Kristol Feb. 1998). These policies ignored the fact that Saddam had made his plans for regional domination clear. The only scenario worse than a hostile Iraq joining an emergent superpower, was an Iraq with regional dominance joining such a power ${ }^{20}$ (PNAC website: Kagan \& Kristol Feb. 1998; Gerecht May 2001). Regime change had to become the new American approach towards these rogue states; it was essential to American security. The threat to world peace came from these unstable regimes, and the regions over which they reigned had to be made stable in order for America and the world to be secure.

While realists and isolationists await for dangers to materialize before they take action, internationalists take action at the very sources of danger, before it materializes ${ }^{21}$ (Kagan \& Kristol 2000: 12). This approach is based on the belief that the conditions of danger "may be significantly ameliorated through the vigorous application of American power and ideals." (Kaplan \& Kristol 2003: 65) Dealing with threats in this manner means that America must ward off potential adversaries that, in the future, could be capable of disrupting international peace and the post-Cold War world order. The success of this mission rests on the ability of American policy-makers to "anticipate the future and also influence it." (Wolfowitz 2000: 316)

The ideas behind this approach to foreign policy existed well before $9 / 11$. The events of that day simply strengthened its resolve, and proved it right. Iraq had been a problem since the early 1990s: "September 11 did not create the threat of Saddam

\footnotetext{
${ }^{20}$ His dominance over the region means his dominance over enormous oil fields.

${ }^{21}$ This point was crucial to the Bush administration when making the case for Iraq's weapons of mass destruction. On September 8 2002, National Security Advisor - Condoleezza Rice - proclaimed in an interview on CNN: "We don't want the smoking gun to be a mushroom cloud." (Quoted in Woodward 2004: 179) This quote was repeatedly used by many administration officials, including the President, while making the case for war.
} 
Hussein, or even make the imperative of dealing with the threat more urgent. Rather, it dramatized a threat that was there all along." (Kaplan \& Kristol 2003: 73) It illustrated the dire consequences of inaction and short-sightedness. The events of 9/11 made clear that domestic security could not be achieved without an assertive and morally-driven American foreign policy. The tyrannical regimes which (1) threatened an international order conducive to American security (both in its present form and its future potential), and (2) spawned the 'swamps' from which terror emerged, had to be dealt with forcefully. The introduction of The National Security Strategy of the United States (Sept. 2002) document made official this shift in national policy:

It transformed the war [on terror] from a police action to round up the perpetrators of September 11 into a campaign to uproot tyranny and export democracy. It also transformed the tenets of a distinctly American internationalism into the official policy of the U.S. government. (Kaplan \& Kristol 2003: 74)

Finally, 9/11 had raised the prospects of a chemical or nuclear terrorist attack on American soil. This left Americans with no choice but to face tyranny forcefully and swiftly, because such an attack could only occur if terrorism and hostile states with weapons of mass destruction (WMDs) combined their forces to attack the US. In this new world, the "old doctrines of security do not apply ... containment is not possible when dictators obtain weapons of mass destruction, and are prepared to share them with terrorists who intend to inflict catastrophic casualties on the United States." (PNAC website: Cheney in Kristol Aug. 2002) This new reality made Saddam a grave threat to American security $^{22}$ :

\footnotetext{
${ }^{22}$ In Chapter Two, I will sum up the points discussed in this 'security' section, and focus solely on how they were used to cast Saddam Hussein as the principal threat to US security and interests.
} 
Armed with an arsenal of these weapons of terror, and seated atop ten percent of the world's oil reserves, Saddam Hussein could then be expected to seek domination of the entire Middle East, take control of a great portion of the world's energy supplies, directly threaten America's friends throughout the region, and subject the United States or any other nation to nuclear blackmail ... Deliverable weapons of mass destruction in the hands of a terror network, or a murderous dictator, or the two working together, constitutes as grave a threat as can be imagined. (PNAC website: Cheney in Kristol Aug. 2002)

To remove him from power, a political-military strategy was needed, and "let's not kid ourselves: In any such ... strategy, the military element is central. ${ }^{, 23}$ (PNAC website: Kagan \& Kristol Feb. 1998) In sum,

The emphasis on preemption derives from the recognition that the world has grown too small and too dangerous to allow, in some instance, the luxury of mere containment ${ }^{24}$. And preemption against dictators developing weapons of mass destruction clearly serves the interest of democracies. The national security strategy seeks to minimize the gap between ideals and interests, between morality and power. It gathers in one place all the major strands of a distinctly American internationalism. (Kaplan \& Kristol 2003: 75)

\section{American Hegemony:}

With the fall of the Soviet Union, America became the world's sole superpower.

No single state, coalition, or ideology could challenge it. The US had entered its "unipolar moment"25 (Kagan \& Kristol 2000: 6). This historical development had to be greeted with enthusiasm by American politicians. After all, this 'unipolar moment' was

\footnotetext{
${ }^{23}$ In 1998, PNAC sent a letter to the office of President Clinton which made a request for such a shift in policy: "The only acceptable strategy is one that eliminates the possibility that Iraq will be able to use or threaten to use weapons of mass destruction. In the near term, this means a willingness to undertake military action as diplomacy is clearly failing. In the long term, it means removing Saddam Hussein and his regime from power. That now needs to become the aim of American foreign policy." (PNAC website: January 1998) This letter was signed by a number of people including: Richard Armitage (deputy Secretary of State during Bush's first term), Richard Perle, Donald Rumsfeld, and Paul Wolfowitz. With the exception of Armitage, another letter was signed by the figures above which carried the same message to the Speaker of the House - Newt Gingrich, and the Senate Majority Leader - Trent Lott (PNAC website: May 1998).

${ }^{24}$ In reference to the George H. Bush and the William J. Clinton approaches.

${ }^{25}$ This is a phrase coined by conservative columnist Charles Krauthammer.
} 
the fruit of America's perseverance in years of fighting hot and cold wars across the globe. Following the Cold War, the goal of American diplomacy should have been to turn this 'unipolar moment' into a "unipolar era" (2000:6). The policies of the 1990s, however, squandered this opportunity. This was a period largely marked by a hesitancy to exert America's hegemonic power - American policy-makers were too concerned with, and even feared, world-wide resentments of such power. The question that should have been asked, however, was: who is behind these voices of resentment? An ambitious China which aims at East-Asian domination, an envious France eager to counter American power in order to promote its own economic and political interests, or a fearful Russia still reeling from its Cold War defeat, just to name a few (2000: 21). Considering such resentments in policy decisions meant that the policy-makers of the 1990s accepted the moral ambiguity of the post-Cold War world as fact; the internationalists do not. These resentments are "to be expected as part of the price for American global preeminence", they do not, "however, add up to a convincing argument against preserving that pre-eminence." (2000: 21) This is because "those who suggest that these resentments could somehow be eliminated by a more restrained American foreign policy are deluding themselves." (200:21)

The problem was not America's power; the problem lay in the actions, desires, and world-views of a few world actors. The fact of the matter was that the preservation of American hegemony was both favorable for America and the world. It was favorable for America because post-Cold War conditions had been "unusually conducive to peace and to the goals and values of the United States, its allies and friends." (Kagan D. 2000: 339) They were conducive in the sense that they allowed for enhanced American sovereignty 
over its domestic policies ${ }^{26}$. Sovereignty here basically deals with the ability of the US to pursue its national interests, whatever they may be, unabated (Kagan R. 2003: 76). This, however, should not arouse the fears of 'hubris' or 'imperialism', because America's national interests are almost always congruent with the world's interests. The push towards world democratization, for instance, serves not only American national interests, but the world's interests as well. Thus,

The strategy of focusing on regime change to foster democracy, writes political scientist G. John Ikenberry, 'is a strategy based on the very realistic view that the political character of other states has an enormous impact on the ability of the United States to ensure its security and economic interests.' For the United States, then, a straightforward argument from self-interest follows naturally: The more democratic the world becomes, the more likely it is to be congenial to America.' (Kaplan \& Kristol 2003: 105)

So, if world democratization achieves a pragmatic goal of self-interest, and it spreads liberty and freedom around the world, then "what is wrong with [American] dominance, in the service of sound principles and high ideals?" (2003: 112). The strategy of regime change was thus not only carried out to deal with immediate threats to American security and to serve American interests. This was also a strategy geared towards the creation of a better and more secure future for the whole world ${ }^{27}$. It combined American national interests with a universal moral cause that would bring peace and prosperity to the international order. The use of American power to transform the unstable regions of the world should not, and largely would not, be feared by others in the world because the US

\footnotetext{
${ }^{26}$ By this I mean economic, political, juridical, as well as foreign policies. The primary concern within this discourse is on foreign policies, and the ability of the US to shape its foreign policies as it pleases. It is this ability that allows the US to then pursue other kinds of policies, and ensure American economic and political prosperity.

${ }^{27}$ An important point behind this thinking is that, historically, this has been America's calling (Kagan R. 2003: 77-78). Lest the world (and especially Europe) forget, the Kantian dream of 'perpetual peace' that is emerging in today's Europe (i.e. the European Union, economic and cultural integration, and the relative disappearance of war within the Western part of the continent) "is very much the product of American foreign policy" (2003: 70-74).
} 
"does not pursue a narrow, selfish, definition of its national interest, but generally finds its interests in a benevolent international order." (Kagan \& Kristol 2000: 22) America's military interventions in these regions would be geared towards the spread of American ideals that are "unalienable, universal, God-given, and therefore all people, wherever they may be, are deserving of them." (Bennett 2000: 294) This approach "is a combination of our self-interest in the stability of the Middle East, Europe, and East Asia, and our broader interest in establishing an international climate that is hospitable to the success of democratic values." (2000: 294) The world's rogue states all combined could not mount a challenge as threatening as that of an indifferent and parsimonious America - one that would allow international peace and democratic principles to collapse (Kagan \& Kristol 2000: 4).

Over-extensive multilateralism had shown itself to be incapable of carrying out such dramatic, progressive, and necessary world transformations. The US has the power to do so, and this power has to be preserved in order for it to continue to be able to do so. Preserving this power can not be accomplished easily; America has to be willing to intervene in the affairs of world actors who wish it harm. This means that "American preeminence cannot be maintained from a distance. The United States should instead conceive of itself as at once a European power, an Asian power and, of course, a Middle Eastern power." (Kaplan \& Kristol 2003: 123)

This period is not a time for America to rest. Its global dominance will not last forever, and its ability to prolong this dominance will depend on how America deals with this particular moment of unrivalled dominance. Failure to adequately deal with this 'unipolar moment' will result in massive human and material costs to America in the 
future. Clarity about one's position, the ability to see foreign countries' intentions for what they are, and the will to act accordingly are all crucial to the preservation and enhancement of American hegemony. History teaches that great powers fall because

They glory in their temporary superiority and imagine it will become permanent with little or no effort on their part. But, as one historian points out, 'wealth and power, or economic strength and military strength, are always relative; ... the international balances can never be still, and it is a folly of statesmanship to assume that they ever could be.' (Kagan D. 2000: 338)

In this case, Americans must realize that contrary to what isolationists, realists, or liberals would have them believe, America is the world's benevolent force. Americans must also realize that certain world actors have intentions hostile to American security and national interests. Most importantly, Americans must realize that these hostile intentions must be met with fierce determination, and the will to fight. In the absence of these three elements from American statesmanship (particularly the latter point), Americans are likely to face devastating wars in the future.

Since the collapse of the Soviets, various world actors began to question the American will to fight (2000: 361). Saddam Hussein was one of them. It was "the weakness of American policy that encouraged Saddam to move against Kuwait"; it was the "'ambiguous policy combining threats with appeasement"" that emboldened him (2000: 362). The excuse for this approach lay in the unwillingness of policy-makers to risk American lives and resources in what they perceived to be 'unnecessary wars'. This approach, however, is counterproductive:

Instead of preventing the expenditure of resources and the risk of American lives, they often create conditions that cause greater expenditure and risk. The twentieth century has repeatedly shown that for a great power, and especially for the world's leading power, there is no escape from the 
responsibility its position imposes. Recent history has also demonstrated that the cost of these burdens is small compared with the costs of failure to bear them forthrightly; and in dealing with the issue of its power, a country like the U.S. is really dealing with its values and its security. (2000:362)

Dealing forthrightly with its international responsibility begins, first and foremost, with its allies. It should be made clear that America's dominance is different than that of the Romans for instance. America is not a central power that dominates all other nations of the world and dictates specific orders to them. America's dominance ... stems more from the fact that all of the economically powerful countries in the world are America's allies. The United States is the leader and the dominant member of that alliance, but it is an alliance of democratic countries, not a collection of satellites responding without question to a superpower's will. (Wolfowitz 2000: 317)

America must diligently pursue the advancement and prosperity of this alliance (Kagan R. 2003: 97-103). Most central to this task is the continuation of the American role as the primary security provider. There is no doubt that the core of this alliance lies in Europe, and just as "Europe's evolution into its present state occurred under the mantle of the U.S. security guarantee" (2003: 72$)$, so will its future ${ }^{28}$. Under America's security umbrella, this alliance can prosper. If it does, then the rest of the world will follow and join it. Ultimately, the surest way of preserving American hegemony is to advance this alliance. Through it, the world can be made conducive to American principles and values - this comprises: democracy, free-trade, and human rights (Bennett 2000: 289-305).

\footnotetext{
${ }^{28}$ This peculiar relationship between America and Europe means that "although the United States has played the critical role in bringing Europe into this Kantian paradise, and still plays a key role in making that paradise possible, it cannot enter the paradise itself. It mans the walls but cannot walk through the gate. The United States, with all its vast power, remains stuck in history, left to deal with the Saddams and the ayatollahs, the Kim Jong Ils and the Jiang Zemins, leaving most of the benefits to others." (Kagan R. 2003: 75-76) Make no mistake, though, this is a relationship Americans are comfortable with (ibid).
} 
Since these principles and values are universal, what is good for America becomes good for the world:

Today, America sits at the summit. Our military strength is the envy of every nation on earth, and our accomplishments as a world power would elicit awe and admiration from every nation that has gone before us.

America has 'the command of its own fortunes.' It would be tragic indeed if we did not use this extraordinary historical moment to promote the ideals at the heart of our national enterprise and, by so doing, take the steps that will ensure stability and the steady growth of freedom throughout the world. (2000: 305)

\section{American Leadership:}

Power always comes at a price; it always comes with a heavy responsibility. America's place in history will be written on the basis of how it acts in its moment of preeminence. The post-Cold War era is precisely that moment. A visionary, sound, and effective leadership is required for America to positively fulfill its role as the world's sole superpower. America did not ask for this leadership role, nor did it forcefully assert itself as such. History demanded it from America.

After the Cold War, some believed that multilateral institutions, such as the United Nations (UN), could fulfill the role of world leader and provide security around the world ${ }^{29}$. This approach, however, is misguided on two levels: (1) the UN lacks the moral authority to carry out a mission as important as the spread of peace and freedom around the world, and (2) it lacks the structure necessary for ensuring security, particularly an effective decision-making structure ${ }^{30}$.

\footnotetext{
${ }^{29}$ One of the important philosophical, or metaphysical, forces behind this thinking can be most clearly seen in the rift between American and European thinking "over where exactly mankind stands on the continuum between the laws of the jungle and the laws of reason. Americans do not believe we are close to the realization of the Kantian dream as do Europeans." (Kagan R. 2003: 91)

${ }^{30}$ The mammoth failures of the UN in places such as Rwanda and Bosnia attest to this fact (PNAC website: Schmitt March 2003; Kaplan \& Kristol 2003: 87-90).
} 
The idea that the UN holds a position of higher moral authority in relation to the US is absurd (Kaplan \& Kristol 2003: 91). When dealing with such a question, Americans need to first ask themselves: what is the UN? The answer is clear: it "is simply a collection of sovereign states. The organization makes no distinctions based on political systems; a tyranny is as welcome as a democracy." (2003: 91) It is laughable to think that an institution which places states like Syria on Human Rights Committees has the moral authority to lead the world. This idea should be quickly dismissed.

Besides the moral backwardness of the UN, its structure for reaching decisions can only breed impotence. For instance, decisions of war and peace are made in the Security Council, where permanent members - Britain, China, France, Russia, and the US - have to reach an agreement over such matters. Needless to say, China and Russia are far from liberal-democracies, and do not uphold the core and universal values and principles of the US and its Western European allies. Their objections to decisions of war and peace are often based on their attempts to "use the UN for their own geopolitical ends." (2003: 91) France is guilty of such practice as well. Since WWII, Europe had grown weak while America had gained enormous power. As a result, it was only natural that former European powers such as France and Germany would use the only tool they have to advance their self-interests: multilateralism (Kagan R. 2003: 38). It was only natural that they would "fear American unilateralism and seek to constrain it as best they can through such institutions as the United Nations. Those who cannot act unilaterally themselves naturally want to have a mechanism for controlling those who can." (2003: 39-40) Much of the French and German opposition to the Iraq war, for instance, was due to this power dynamic; it was not based on moral reasons. They felt threatened by 
American power, because that power questioned the viability of the Europe which emerged from WWII,

America's power and its willingness to exercise that power - unilaterally if necessary - constitute a threat to Europe's new sense of mission. Perhaps it is the greatest threat. American policymakers have found it hard to believe, but leading officials and politicians in Europe really have worried more about how the United States might handle or mishandle the problem of Iraq - by undertaking unilateral and extralegal military action - than they have ever worried about Iraq itself and Saddam Hussein's weapons of mass destruction ... Such American action, even if successful, is an assault on the essence of 'postmodern' Europe ${ }^{31}$. It is an assault on Europe's new ideals, a denial of their universal validity ... After all, to deny the validity of the new European idealism is to raise profound doubts about the viability of the European project. (2003: 61-62)

Simply put, multilateralism is nothing more than a tool of the self-interested weak to suppress the strength of the powerful. Thus, consensus in the Security Council in particular and the UN in general, is almost impossible to reach ${ }^{32}$. It only produces impotence $^{33}$; its only aim is to inhibit American power simply because some in this world fear it. Who fears it? The theocracy of Iran, the tyranny of Saddam, the authoritarianism of China, and the self-interested and hypocritical France ${ }^{34}$, Germany, and Russia.

\footnotetext{
${ }^{31}$ This is another example of how this discourse views the moral relativism of the postmodern age as its ultimate philosophical enemy.

${ }^{32}$ This was evident in the Iraq War. The Security Council resolutions for inspections only created a "trap" for the Bush administration in an attempt to postpone or eliminate military action against Saddam (PNAC website: Kagan \& Kristol Nov. 2002).

${ }^{33}$ One of the leading figures who detested the UN approach was Vice President Dick Cheney. He continuously argued against taking the Iraq case to the UN or the Security Council: For him "going to the UN would invite a never-ending process of debate, compromise and delay. Words not action." (Woodward 2004: 157) This point was at the center of the heated debates within the administration between Cheney (the war-machine) and Secretary of State Colin Powell (the diplomatic approach) (2004: 156-261).

${ }^{34}$ The point of French hypocrisy is often cited in this discourse. For instance, a report from the Washington Post is cited here to expose French hypocrisy: "Even as [Prime Minister] Chirac was proclaiming the sanctity of the United Nation's authority over war-making, some 1,000 French troops were intervening unilaterally to protect French interests in Ivory Coast" (Quoted in Kaplan \& Kristol 2003: 91). In another instant, Richard Perle focuses on French interests in maintaining oil contracts with Saddam's regime as well as France's desire to create a counterweight to American power as the real reasons behind French opposition to the war (PNAC website: in Schmitt Feb. 2003).
} 
The inaction of multilateralism is disastrous for the world. If anything is to be achieved in this world, America must fill the role of leadership - and this means acting alone if necessary. The moral character of the $\mathrm{UN}$, and that of the countries which oppose American power through it, must be made clear to Americans and the world. Those who wish to choose peace, prosperity, and order have nothing to fear from America's power. Indeed, they can bask in its light. America still shares the dream of a world governed by the rule of law, and not by any one single power. However, in order for this to occur, America must first build a world that could be governed by the rule of law (2003: 41-42). The international community is simply not there yet. This world remains a dangerous one, and until this fact changes, military force and might is needed (2003: 95). A more peaceful future can only arrive with the aid of American power:

A world at peace; a world governed by law; a world in which all peoples are free to find their own destinies: That dream has not yet come true, it will not come true soon, but if it ever does come true, it will be brought into being by American armed might and defended by American might, too. America's vocation is not an imperial vocation. Our vocation is to support justice with power. It is a vocation that has earned us terrible enemies. It is a vocation that has made us, at our best moments, the hope of the world. (Frum \& Perle 2003: 279)

In case of the Iraq War, the question is not whether or not the US had the right to act "alone" ${ }^{\sharp 5}$; it is whether or not the US acted positively, and the answer to that question was clear even before the war began:

There is nothing reactionary about wanting to rid the world of a dictator who gasses his own people, invades his neighbors, developed weapons of mass destruction, and flouts an entire catalogue of U.N. resolutions. As the New Republic has editorialized, "the important question is not whether other

\footnotetext{
35 'Alone' here only refers to the fact that the war was not sanctioned by the UN. A number of countries (most notably Britain, Australia, and initially Spain) did indeed join the US in the war effort, and aided them financially, politically, and militarily.
} 
countries agree with the United States but whether those countries are right." In the case of Iraq, they are not. (Kaplan \& Kristol 2003: 94)

In this instance, America is not so much acting unilaterally. Rather, it is acting as a good leader. America is the only world actor qualified to lead the world and transform it into a better place for everyone to inhabit. This necessity to lead and the aim of creating peaceful international co-existence are behind the assertion of American power, not the 'will to power' or the aim of world domination. The alternative to America's benevolent influence in the world is "a chaotic, Hobbesian world where there is no authority to thwart aggression, ensure peace and security or enforce international norms." (2003: 121)

If some in the world perceive this as American unilateralism, then so be it. They are not the ones being targeted for hatred directed at the West - America is. Being the leader and protector of liberal-democratic states brings the burden of facing the ideologies of hate alone, and therefore being their primary target of attack (Kagan R. 2003: 34). In the case of Iraq, America was unilaterally acting to ensure international peace and its own security:

... we want support in the UN, we want the approbation of the UN, but no American government can allow the defense of this country to depend on a show of hands at the United Nations or anywhere else. If that sounds unilateralist, so be it. I think at the end of the day that would be the attitude of France or Germany or China if they felt that they were threatened in the way that we now consider we are threatened. The fabric of the UN, of the international community, is just not strong enough now that we would be ready to abandon our sovereign right of self-defense in the hope that some other structure is going to protect us ... We're bound, I think, to be unpopular simply by virtue of the strength of our position. We didn't ask for it that way, but that's the hand history has dealt us and we can't give the cards back. (PNAC website: Perle in Schmitt Feb. 2003) 
This was a war of necessity; it was necessary for the Middle East, the US, and the world.

Order, peace, and the cause of civilization were at stake; and nothing short of the world's moral, political, economic, and military leader was necessary to answer the call of History. America and the world cannot lose sight of "the simple but fundamental point ... that it matters more what purposes our power serves than that we have power." (PNAC website: Schmitt March 2003) The American mission now is to stay the course and to fulfill this historical mission. Iraq was merely the first step:

The mission begins in Baghdad, but it does not end there. Were the United States to retreat after victory into complacency and self-absorption, as it did the last time it went to war in Iraq, new dangers would soon arise. Preventing this outcome will be a burden, of which war in Iraq represents but the first installment. But America cannot escape its responsibility for maintaining a decent world order. The answer to this challenge is the American idea itself, and behind it the unparalleled military and economic strength of its custodian. Duly armed, the United States can act to secure its safety and to advance the cause of liberty - in Baghdad and beyond. (Kaplan \& Kristol 2003: 124-25)

The maturation of America has reached a new stage in the post-Cold War era. It represents the dawn of global American leadership, and its moment to set the course of History.

\section{A Vision and Strategy for America}

The different components of the discourse combine to produce a specific vision and strategy for America. I will discuss this vision with reference to the themes already developed, mainly dealing with: the detestation of ambiguity and moral relativism, the feeling of unchecked and superior strength, and the new security environment of the $21^{\text {st }}$ century. 


\section{(I) A Vision for America in the $21^{\text {st }}$ Century:}

The neoconservative movement develops within this discourse a vision for America that is necessarily tied to a vision for the world order. In this world order the discourse's architects argue that two important points must exist with world-wide clarity: (1) the hierarchical order of nation-states, and (2) the political and economic systems that form the normative basis for judgment in the $21^{\text {st }}$ century. Both of these points are to be decided on the basis of the Cold War. This grand battle of 'good vs. evil' produced a definitive winner: the US and its allies. Thus, in regard to the first point, the discourse argues that the US and its allies are entitled to the position of political global leadership. In regard to the second, liberal democracies, deregulated economies, free trade and open markets, which were the clear winners of the Cold War, represent the wave of the global future. In short, this world order would be built around the triumphant forces of 'good'. More specifically, it will be based on the spread of a free-market global economy and liberal democracy through the guidance of a Western alliance under the leadership of the US. While this order is morally beneficial for the world, the most pressing need for establishing such an order still remains the preservation and enhancement of American prosperity, sovereignty, and its domestic security - i.e. this order is strategically beneficial for the US (PNAC website: June 1997) ${ }^{36}$.

The perceived necessity for this world order stems from the neoconservatives' view of the post-Cold War security environment. In this environment, America must contend with a number of global security threats. The two oceans that have protected it in the past no longer form the formidable barriers they once did. This security environment

\footnotetext{
${ }^{36}$ The Statement of Principles document was signed by a number of people including: Dick Cheney, Lewis Libby, Donald Rumsfeld, and Paul Wolfowitz.
} 
consists of three elements. In order of importance: (1) the possibility that a hostile superpower will rise and challenge US hegemony, (2) hostile rogue states that already possess, or are near possessing, WMDs, and (3) terrorist cells, which formed small units that could maneuver with great stealth and inflict a great deal of destruction. The rogue states are arguably the most unique of these three threats. They can play a role in strengthening both the first and third elements. They can ally themselves with a future hostile superpower, and supply it with necessary resources; and they can combine forces with small terrorist cells and thus increase the terrorists' potency (e.g. supply them with WMDs, intelligence, or simply embolden terrorists from a distance). Thus, any vision for America's future has to consider ways of eliminating these threats (or at the very least, reducing their potency) if it is to ensure American security in the future - if it is to rebuild the security the two great oceans once provided. Since rogue regimes form a double-barreled threat, their removal is integral for it would reduce the potency of the first and third elements of danger, not to mention the second in its own right.

Although security is of foremost importance to this vision, economic prosperity and political hegemony are also of immense importance. Indeed, these three elements are interconnected and interdependent in the discourse. The stronger America is economically and politically, the more it is effective in pursuing its enemies and crushing them. Conversely, the more secure America is, the more it is able to maintain and enhance its economic prosperity and political hegemony. For the neoconservatives, it is a great myth that economic prosperity and political hegemony alone can bring about peace and order. Peace and order must be established and maintained separately and in congruence with economic prosperity and political hegemony in order to ensure their 
sustenance (Kagan \& Kristol 2000: 7-9). American economic and political power is not everlasting or invincible; it must proactively be maintained and enhanced for the future. The discourse's architects basically aim to sustain and enhance America's strategic interests born of their triumph in the major wars of the $20^{\text {th }}$ century:

The United States had assumed an unprecedented position of power and influence in the world ... American military power dwarfed that of any other nation ... There was a common acceptance ... that America's position as the sole global superpower might not be challenged for decades to come. Meanwhile, the American economic precepts of liberal capitalism and free trade had become almost universally accepted as the best model for creating wealth, and the United States itself stood at the center of that international economic order. The American political precepts of liberal democracy had spread across continents and cultures as other peoples cast off or modified autocratic methods of governance and adopted, or at least paid lip-service to, the American credo of individual rights and freedoms. American culture, for better or for worse, had become the dominant global culture. To a degree scarcely imaginable at mid-century, or even as late as the 1970 s, the world had indeed been transformed in America's image. (Kagan \& Kristol 2000: 5)

To sum up, the vision within this discourse is of a world order that is directed by America and its allies. The US would be the leader of this alliance structure, but by no means its 'dictatorial' leader. This leadership would rather resemble a network of power, rather than one dominant power dictating orders to its subordinates. Along with its allies, the US would exert its power to establish and maintain a peaceful and prosperous world for all of humanity - it would build the world Woodrow Wilson dreamed of. Most importantly, such a world structure would enable America to maintain and enhance its economic and political power. This will allow the US to continuously build a secure homeland where Americans can pursue economic, political, and cultural prosperity free from all of the constraints of any given international system. As leader of the globe, 
America would maintain and enhance the priceless position of having sovereignty over its domestic policies and national directions.

So, what kind of strategy can policy-makers use to pursue such a vision? The discourse's architects argue that for American power to be maintained in the future, America has to "lean forward" in its foreign policy, and "meet the standard of a global superpower that intends to shape the international environment to its own advantage." (Kagan \& Kristol 2000: 14)

\section{(II) A Strategy for America:}

The defining feature of the neoconservative strategy is its aim to eliminate perceived dangers at their roots, before they reach American soil. This means that America has to expand its influence around the globe, particularly in the regions which formed an immediate threat to America's strategic interests (e.g. the Middle East and its militant Islam $)^{37}$.

In the $21^{\text {st }}$ century, the discourse's architects argue, America can no longer watch rogue regimes from a distance. The idea of "regime change" has to become a "central component" of America's strategy in foreign policy (Kagan \& Kristol 2000: 19). There are, of course, multiple methods to carry out regime change, and each specific case ought to be treated differently (Frum \& Perle 2003: 98-121; PNAC website: Schmitt July 2003). Such methods include encouraging internal rebellion, the use of diplomatic pressure, offering economic incentives for introducing reforms, etc. (Frum \& Perle 2003: 98-121). However, because of the neoconservatives' firm belief in the superiority of America's political institutions and military might, along with their view of humanity as still moving

\footnotetext{
${ }^{37}$ This will be discussed more closely at the beginning of Chapter Two.
} 
in the 'laws of the jungle' direction, the discourse's architects were more likely, or less hesitant, to advocate the use of force for the sake of enhancing America's strategic interests. What is at work here is simple: humanity has not advanced very far in the 'laws of reason' direction. Indeed, much of humanity still operates on the 'laws of the jungle' path; many only understand the language of force. Faced with this reality, Americans should not hesitate to utilize their unmatched military capabilities when American interests are at stake. Lest we forget, those who oppose America would jump at the chance of utilizing such military capabilities against America if presented with such a scenario.

In short, this foreign policy strategy takes a page from Theodore Roosevelt's approach. It embraces American power and does not feel ashamed of it. It faces America's responsibility in the world and does not hide from it. Finally, it believes that war can bring peace and progress to the world, not always destruction and chaos. Roosevelt "did not attempt to wish away the realities of power; but insisted that the defenders of civilization must exercise their power against civilization's opponents. 'Warlike intervention by the civilized powers,' he insisted, 'would contribute directly to the peace of the world'." (Kagan \& Kristol 2000: 23)

The spread of democracy and free trade are at the center of America's strategy for the $21^{\text {st }}$ century. Through the expansion of such political and economic institutions, American security and hegemony can be enhanced and preserved. Any attempts to challenge this expansion are to be met fiercely. Rogue regimes which attempt to disrupt the road towards this international order should not be negotiated with - they would be transformed. Because the neoconservatives wished to transform these regimes before 
they materialized into a full-fledged threat, pre-emption became indispensable to their strategy $^{38}$.

\section{Concluding Remarks}

Based on this exploration of the discourse, two important features of it stand out. The first involves the 'isolationism-expansionism' tension. In Empire, Hardt \& Negri differentiate between their concepts of 'imperialism' and 'empire' by arguing that Roosevelt's approach resembled that of past imperialism (i.e. to spread power linearly), while Wilson's approach resembled that of contemporary empire (i.e. power that operates in networks). Furthermore, they argue that American power in contemporary times is only built on, or operates on the basis of, the Wilsonian approach (Hardt \& Negri 2000: 174-82). I agree with their differentiation between the two approaches. However, I disagree with their assessment of contemporary American use of power. I believe that the neoconservative discourse is infused with elements from both.

This Wilson-Roosevelt combination is a defining feature of the discourse. While it aims to build a world 'beyond power', where power is spread across networks rather than a central power, it argues for an approach that is very much influenced by Roosevelt's. It advocates a forceful America, one that exercises its political, economic, and most importantly its military might around the world unabated. For the discourse, America must utilize Roosevelt's approach in order for it to build Wilson's dream. What is Wilson's dream according to the discourse? It is a world where Americans can enjoy freedom from the world, where they are not forced to 'police' it, to solve its problems, or to protect the causes of freedom and liberty from 'evil' enemies. Only networks of power

\footnotetext{
${ }^{38}$ Pre-emption will be discussed more closely in chapter two.
} 
can take this heavy burden away from America's shoulders. Such networks, however, would largely be of America's own making, and thus entitling the US to the sole position of leadership ${ }^{39}$. This position would in turn allow America to pursue cultural, economic, and political prosperity free from the world - largely isolated from its problems and dangers. After all, they are the ones who would build this stable world order; this is where Roosevelt's approach comes in. This approach involves an aggressive and forceful America, which does not shy away from its responsibilities. It involves the use of all of America's might to advance the cause of civilization - i.e. to expand America's influence around the world forcefully if need be, so that one day, the world could be run by networks of power. Thus, the discourse does not favor Wilson over Roosevelt or visa versa. It rather attempts to fuse the best elements of each in order to build a new direction for American foreign policy in the $21^{\text {st }}$ century - a direction that would transform America's 'unipolar moment' to America's 'unipolar era'.

The second feature involves the two-level thinking of the discourse. The discourse clearly states that its foremost concerns are the strategic interests of the US; but as a result of its fierce opposition to moral relativism, the discourse is forced to consider moral thinking in its arguments as well. In short, the higher and more important level is strategic thinking. The second, lower level involves moral thinking. As previously discussed, the discourse considers these two levels to be inextricably intertwined - i.e. what is morally good is also strategically beneficial for America. What is crucial is to

\footnotetext{
${ }^{39}$ There is an interesting intersection here between the neoconservative discourse and the new RMA of Ullman and others discussed earlier. When making the case for RD, Ullman \& Wade argue that once this strategy establishes itself as the new and revolutionary method of conducting war in the coming century, America would guarantee itself the sole position of military leadership in the world. They envisioned that an arrangement similar to NATO's would take place, where America leads unquestioned with its allies fulfilling the 'minor' tasks of conducting war (e.g. peacekeeping) (Ullman \& Wade 1998: 84).
} 
keep in mind, however, that the two levels can be as easily divorced as they were easily brought together by the discourse. That is, the use of moral thinking is primarily brought up as it is beneficial for American strategic interests, not because it is beneficial in its own right. Put differently, morality is principally a means to an end, not an end in itself. This means that if morality does not produce beneficial strategic results, it can be dropped for it ceases to serve the purposes - the primary purposes - it is called upon to serve.

To conclude, the neoconservative discourse has two important features that permeate it. The first is that it aims to fuse two approaches to foreign affairs that seem incompatible, hence producing an important tension in the discourse: 'isolationismexpansionism'. The second is that it operates on two levels of thinking: one strategic, the other moral. The relationship between these two levels is not symmetrical. Strategic thinking overrides the second level of moral thinking. It dictates its form and utility, and indeed its very presence in the discourse. So, what do these two features mean for a critical analysis of the discourse? At this present stage of description, it is difficult to say - the discourse is far too abstract when issues of power and the world order are being discussed. In order to address this question, I will next examine the two-step plan the discourse's architects devised to deal with Iraq. This closer focus will allow me to highlight both these features and, eventually, how these points help us in a critical examination of the neoconservative plan and, ultimately, their approach to foreign affairs in general. 


\section{Chapter Two}

\section{'Targeting Saddam: The Two-Step Plan'}

The vision and strategy discussed previously produced a specific tactic aimed at dealing with Iraq. This tactic involves a two-step model: de-construction and reconstruction. The first step deals with the use of pre-emptive war and the removal of Saddam (i.e. the deconstruction of Iraq); the second step deals with the erection of American-style democratic institutions in his place (i.e. the reconstruction of Iraq). Following this discussion, I bring the two features of the discourse highlighted earlier into focus. But before I engage in these discussions, I will spend a brief moment to clarify why Saddam was targeted - i.e. why Saddam was considered the principal immediate threat to American interests and security.

\section{Target: Saddam}

Why Saddam?' It is a simple formula that operates on the three levels of global security threats. The first level involves Saddam's threat to America and its allies in his own right. He was known to be an enemy of the US (i.e. he defied American interests during his 1991 invasion of Kuwait - an American ally), and removing him would thus

\footnotetext{
${ }^{1}$ It should be kept in mind that academics do not yet have the necessary access to official government documents to fully answer this question. The answer I provide here points to the general framework from which Saddam was viewed as the principal threat to the US. However, the nuances of choosing him are not yet known - although many speculations (especially predominant in the media) exist (e.g. Israel's role, this plan as really an indirect method of cutting ties with Saudi Arabia as Iraq slowly becomes America's main oil exporter, a personal grudge George W. Bush holds against Saddam because he tried to assassinate his father, etc.). Some academics have, however, attempted to depend solely on a historical overview of the relationship between Saddam and the US as the basis for explaining his choice as a target (see Mamdani 2003). While insightful, such attempts still suffer from the lack of access to more recent government documents concerning this issue.
} 
eliminate an American enemy that has caused harm to American interests in the past. The other two levels, however, are of more importance to the discourse's architects in this particular case ${ }^{2}$.

The second level involves the grand strategic interests of the US. As previously mentioned, the greatest concern expressed within the discourse is the rise of a hostile superpower in the $21^{\text {st }}$ century. The most likely candidate for this is China - or at the very least, it would not likely be a Middle-Eastern power. Placing the US in an advantageous position before such a confrontation transpires means actively working to deprive this future superpower of essential resources. One of the most essential resources for any such undertaking is oil. Since Saddam was known to desire regional domination (which translates into domination of oil), it only makes for prudent strategic planning and thinking to assume that he would jump at the chance of forming a formidable alliance with an emergent superpower primed to challenge US hegemony. Presented with this grave scenario, the discourse's architects perceived that action was necessary. By removing Saddam and installing a US friendly democratic Iraq in his place, the US can deprive a potential superpower of an abundant flow of this all-important resource: oil. Third is the concern with America's immediate enemy: militant Islam. The neoconservatives believed that a strong message had to be sent to the Arab world through Saddam's removal. The Arab masses had to be shown that the US is still the 'strongest horse' in the region. They had to be shown that the tactics of terror, defiance, and violent opposition to American interests and security are fatalistic and nihilistic tactics, not rejuvenating and reviving ones. Ever since Saddam remained in power, he has flouted the

\footnotetext{
${ }^{2}$ I say 'in this case' because this level would be considered more dangerous when speaking of a threat such as North Korea's for instance. Saddam's location in the Middle East, and his relative weakness because of the sanctions, place him on a lower level of importance than the threat of terrorism.
} 
US and the international community. He was becoming, in the eyes of many Arabs, a heroic figure who successfully defied American hegemony. Put simply, he was beginning to appear as the 'strongest horse' in the region. The neoconservatives wanted to change this well before $9 / 11$, but the political will was lacking. After the attacks of that day, the US government changed directions and began to see the necessity for showing the Arab world what Saddam really was: a fatalistic, weak, and ruthless leader. His presence only emboldened the terrorist networks, and encouraged many young Muslim men to join such networks because they truly believed that their 'jihad' could prevail: i.e. if Saddam could do it, why can't we? If the minds of these young men were ever to be changed, the 'strongest horse' of the region - Saddam - had to be defeated swiftly and convincingly for all in the region to witness. America's 'hayba' (its awe) had to be re-established. Whether Saddam actually had ties with terrorist networks or whether his interests collided or coincided with such networks, these are debatable points, but they are not the deciding factors for settling the debate over Saddam's removal (PNAC website: Sept. $2001)^{3}$. At the very least, Saddam shared an enemy (the US) with these networks, and if he appeared successful in fighting this enemy, then the terrorist networks would simply think, why not us? (Frum \& Perle 2003: 234)

These strategic obstacles to American hegemony and security made Saddam America's primary enemy in the immediate sense. Faced with this fact, the discourse's architects believed that the US had no other choice but to act against him. The only question left was how.

\footnotetext{
${ }^{3}$ The prospect of Saddam supplying terrorist networks with WMDs remained a real possibility for the discourse's architects, and played an important part in their decision to target Saddam. This will be discussed shortly.
} 


\section{The Two-Step Plan}

I. The Deconstruction of Iraq - The Use of Pre-emptive War.

Architects of this tactic argue that pre-emption is not as 'new' and 'controversial' as many have made it out to be. It is a strategy as old as war itself, with numerous examples of it throughout history (Kaplan \& Kristol 2003: 85-86). In the security environment of today's world, the US could not afford to wait for its enemies to attack American soil with WMDs. The damage of such an attack would simply be too high for America to bear. Since the US is in a position of superior power relative to the world, it can and must approach threats, or more properly, potential threats accordingly.

The differing psychologies of power and weakness are easy enough to understand. A man armed only with a knife may decide that a bear prowling the forest is a tolerable danger, inasmuch as the alternative - hunting the bear armed only with a knife - is actually riskier than lying low and hoping the bear never attacks. The same man armed with a rifle, however, will likely make a different calculation of what constitutes a tolerable risk. Why should he risk being mauled to death if he doesn't have to? (Kagan R. 2003: 31)

If acting prudently can avoid a catastrophic attack on American soil, then policy-makers should not hesitate to take the necessary steps to do so. One of these steps involves the use of a pre-emptive attack on America's enemies. Of course, the important question here revolves around the concept of imminence. On what grounds, or on the basis of what level of intelligence, can the US justifiably attack its enemies preemptively? The answer to this question can never be as clear as we may wish it to be. Absolute certainty in intelligence on such matters simply does not, and cannot, exist. In order to address this question, therefore, we must first closely scrutinize the concept of imminence. 
In a world where nuclear weapons proliferation is increasingly becoming difficult to manage, our understanding of imminence must adapt along with this new reality. Imminence should no longer mean that a hostile state is already pointing nuclear warheads in our direction. If the US allows this to happen, then it would already be too late to act in self-defense - only the fear of 'mutually assured destruction' would prevent acts of hostility towards the US in such a circumstance. While the latter strategy may defend the American homeland, it is politically disastrous ${ }^{4}$. It would prevent the US from fulfilling its historical mission of creating a peaceful and hospitable world order. America would be forced to co-exist with tyrannical regimes such as Saddam's. It is this undesired consequence that prompted the shift from deterrence thinking to pre-emption thinking:

Today we may attack Iraq with minimal risk because Saddam has yet to acquire a nuclear bomb. Once he does, the equation changes. Then it is we who will be deterred ... the unpalatable choice offered by advocates of deterrence [is]: Assume Saddam is a madman and wait until he assembles the tools of aggression, or assume he is rational and wait until he assembles the tools of aggression. (Kaplan \& Kristol 2003: 83)

Thus, if the US wishes to avoid such a circumstance, it must act to prevent hostile states from acquiring nuclear weapons in the first place. This means that a new understanding of imminence emerges. Imminence no longer deals with the heightened possibility of an actual attack; it rather deals with the possibility that a hostile state is close to crossing a specific threshold in nuclear weapons production - a threshold that, once crossed, would make it too late for the US to defend itself outside the strategy of mutually assured destruction. Intelligence, therefore, should not simply focus on whether

\footnotetext{
${ }^{4}$ Defending the US homeland from such attacks is also doubtful when such weapons are in the hands of violent and unpredictable tyrants.
} 
or not certain states have nuclear weapons. It should also focus on how close certain

states are to acquiring nuclear capabilities. This is summed up by Richard Perle here:

Let me say a word about what you call the new strategy of preemption. There's nothing new about preemption. If you know that you are about to be attacked, it is certainly sensible if you can act first and avoid that attack to do so. I don't think anybody would dispute that. So then the question is how imminent must the attack be to justify the preemptive response. Here, we need to think more carefully about the concept of imminence. In 1981, the Israelis ... decided to destroy the reactor that Chirac had sent to Osirak, not because it was about to produce nuclear weapons. It wasn't ... Now, why did they do that? They did it because the Iraqis were about to load fuel into the reactor and once they did so, they would not have had an opportunity to use an air strike without doing a lot of unintended damage around the facility, because radioactive material would have been released into the atmosphere. So from an Israeli point of view, what was imminent and what had to be acted against in a preemptive manner was not the ultimate emergence of the threat but an event that would lead inexorably to the ultimate emergence of the threat. They had to deal with a threshold that once crossed, they would no longer have the military option that could be effective at that moment. If we think of imminence in that sense, if we think of it as the thresholds that once crossed will so worsen our situation that we can't allow those thresholds to be crossed, then you start looking at how far are they from achieving the means to do the thing that everyone would recognize we were justified in stopping at the moment that action was taken. (PNAC website: Perle in Schmitt Feb. 2003; emphasis added)

With this understanding of imminence in mind, pre-emptive war becomes less indicative of a controversial strategy, and more indicative of a prudent one. It represents a much needed shift in policy thinking: "resist aggression with force if necessary, and sooner rather than later." (Kaplan \& Kristol 2003: 115) The next question is: how is this preemptive war to be carried out? The answer lies in the new military strategy developed by Ullman (and others) - Rapid Dominance (RD) . $^{5}$

\footnotetext{
${ }^{5}$ The clearest evidence of a shift towards RD within the Bush administration is in Donald Rumsfeld's insistence on changing the military plans of the 1990s (Woodward 2004: 33-54), and in his continuous use of the term "shock and awe" during press briefings surrounding the war. Most importantly, the shift towards creating and deploying a lighter and faster force was evident in the documentation of military
} 
$\mathrm{RD}$ emerged out of the idea that "America's military power might be made more effective if it principally were constructed on affecting, influencing and, ultimately, controlling the will and perception of an adversary" (Ullman \& Wade 1998: v-vi). In order to work in this direction, a tactic of "shock and awe" was required. Such a tactic "would have to be sufficiently powerful, frightening, intimidating and threatening to convince, compel or scare an adversary into accepting the imposed strategic, political, or operational aims and objectives." (1998: vi) In the post-Cold War world, RD is meant to act as the general military strategy, and 'shock and awe' as the tactic to address this new strategy:

Rapid Dominance is a concept for structuring, using and deploying force to affect the will, understanding and perception of an adversary through the employment of shock and awe. Shock and awe are the means to force or induce the adversary to accept our aims or intent. (1998: 12)

There are many important characteristics that define this approach, many of them technical dealing with issues of command and control structuring, weapons manufacturing, etc. The most important strategic characteristic of this approach lies in its focus on affecting or breaking the enemy's will and perception, rather than destroying the enemy's military infrastructure ${ }^{6}$. In other words, the concern is not on how many enemy tanks, aircrafts, bases, or ships are destroyed; the concern is on how hard the enemy is willing to fight.

Rapid Dominance, by definition, is directed at affecting and influencing the thought process and decision structures of the adversary, including civilian populations where relevant, in order to force, induce or convince the enemy

briefings to the president and the NSC [National Security Council] leading up to the Iraq War (Woodward 2004: 55-56, 60-62, 145-48)

${ }^{6}$ This, of course, is nothing new. For instance, Clausewitz argued that breaking the enemy's will is the single most important objective in war (Clausewitz 1943: 284). What is distinct here is the speed with which this would be accomplished. 
to accept our terms and our will ... Rapid Dominance deals with setting the requirements for capabilities and actions that maximize an adversary's sense of intense vulnerability and of our invulnerability; that convince an adversary of the inevitability and rapidity of destruction and defeat; that create a sense of hopelessness and impotence that intensify fear; and that create confusion, chaos and even paralysis sufficient to overwhelm an adversary's ability to react and resist. (1998: 21)

Shock and awe is the best tool available to reach these ends that RD seeks to achieve. Shock and awe essentially entails an attack, or rather a wave of attacks, which is relentless, deadly, rapid, and efficient. In order for shock and awe to work, this wave of attacks must use "sufficient force" (1998:21). 'Sufficient force' not only deals with missiles and firepower, but it also deals with the ability of the US to have full tactical, strategic, and executive control over the battlefield. This entails complete knowledge of American capabilities, of the adversary (weaknesses, strengths, the relationship between the masses and the leaders, etc.), and finally of the battlefield (1998: 15-19). It also entails the capability of the US to execute brilliantly on the basis of this complete knowledge: "few capabilities instill shock and awe more than the understanding that one is up against a superior, irresistible, and supremely competent adversary." (1998: 17)

Finally, and most importantly to the neoconservative discourse, the ability to deliver this force rapidly, simultaneously, and relentlessly means that the adversary (or a potential adversary) will fear American power regardless of whether or not American forces are present in the region of interest. It raises the stakes for the enemy. They will understand that an American strike will not be akin to a 'warning shot', but rather to a devastating attack. This ability to strike forcefully from a distance is the foremost advantage of deploying shock and awe, and adopting a strategy of RD (1998: 16). 
As mentioned in Chapter One, RD's ultimate aim is to provide policy-makers with maximal political flexibility and leverage (1998: 1-2). Its "principle intent [is] to expand and broaden the political-military 'tool kit' available to the president and to the nation in several strategic and operational dimensions including time." (1998: vii) The main source of this political flexibility and leverage would come from America's ability to respond with $\mathrm{RD}$ "across the entire spectrum of peace, crisis, and war" (1998: vii). RD would provide policy-makers with a strategy that is "timely and usable regardless of whether or not the United States had forces on station in the region of interest." (1998: vii) With the ability to strike hard, fast, and at will, the US could utilize its superior military power to impose its will upon its enemy with relative ease and within a short period of time ${ }^{7}$ :

A potential adversary or party with whom our interests could collide would understand that, through Rapid Dominance, the United States was capable of imposing a great deal of pain and pressure should it be so inclined ... To the degree that Rapid Dominance actually can affect will and perception, it would certainly influence the thought processes of the leadership of those states probably to act with caution and more care. (1998: 77-78)

Since today's world requires the US to shape the international landscape in a way that is conducive to American interests and ideals, a new 'tool-kit' is required to allow policy-makers to pursue that end (1998: 92). The new threats and enemies of the US are no longer of the traditional type (e.g. the USSR). A traditional military, therefore, would not be effective in dealing with such enemies. RD provides the US with the capabilities

\footnotetext{
${ }^{7}$ It is important to note that while the authors make this case, they fully admit that RD does not guarantee this outcome. They realize that since this is a new strategy, no one can say with certainty what it will produce or what its unintended consequences would be. In their view, however, this does not provide a legitimate ground for an outright dismissal of their ideas. They rather encourage "a rigorous and objective effort to evaluate and identify the advantages and possible misuses and then to determine what remedies, safeguards and preventatives can deal with these potential concerns." (1998: 80)
} 
necessary to overthrow rogue regimes, as well as the capabilities to deter other rogue regimes from continuing their political, economic, and military hostility towards the US, its interests, and its allies (1998: 94).

For the neoconservatives, Saddam Hussein was a threat to American hegemony, American allies' security, Middle Eastern stability, and the world's international order. The US had the capability to remove Saddam from power, and to do so rather quickly. It was only prudent to do so. The mission, however, would not end there. America's superiority to these tyrannical regimes would only be used to achieve the end of spreading democracy around the world. In Saddam's place, a democratic Iraq would be established. This will not only send a powerful message to the tyrannical rulers of the region (most importantly Iran and Syria, but also the likes of Egypt and Saudi Arabia), but it would, more importantly, send a powerful message to the Middle Eastern masses. The latter is a crucial point for this tactic. The Middle Eastern masses must be made aware that the US is there to help them, not to fight them. This message must be communicated to them, and the reconstruction of Iraq is the most effective method for this communication. It would show the masses that the US only aims to harm the corrupt leaderships of the region; that the US is there to liberate the people. This message should not be too difficult to communicate since the relationship between the masses and their leaderships in the region is far from firm.

The US is dealing with generally unwanted rulers here. The masses would surely greet the American soldiers as 'liberators', not 'occupiers" ${ }^{9}$. Whatever their differences,

\footnotetext{
${ }^{8}$ This proclamation was made famous by Dick Cheney in an interview on Meet the Press with Tim Russert on March 16, 2003: "I really do believe that we will be greeted as liberators. I've talked with a lot of Iraqis in the last several months myself, had them to the White House ... The read we get on the people of Iraq is there is no question but what they want [is to] get rid of Saddam Hussein and they will welcome as
} 
all Iraqis share one important feature: living under Saddam's brutal regime, and the desire to find non-violent compromises between the Iraqi people (PNAC website: Gerecht May 2001). Thus, the majority of them would surely welcome any force that would free them from this oppressive and brutal regime 9 . While making the case for war, Cheney stresses, As for the reaction of the Arab 'street,' the Middle East expert Professor Fouad Ajami predicts that after liberation, the streets in Basra and Baghdad are "sure to erupt in joy in the same way the throngs in Kabul greeted the Americans.' ... Today in Afghanistan, the world is seeing that America acts not to conquer but to liberate, and remains in friendship to help the people build a future of stability, self-determination, and peace ... With our help, a liberated Iraq can be a great nation once again. (PNAC website: Cheney in Kristol August 2002)

Behind this idea is the notion that the Middle-Eastern masses, from Tehran to Baghdad to Kabul, "want to be like America" (Frum \& Perle 2003: 275-76). They want democracy, but are unable to introduce it to their region by themselves (2003: 278). Simply put, they want to be, and need to be, liberated from the oppression and tyranny in which they find themselves. The US can aid them in achieving this most noble of goals. Policy-makers cannot be afraid to use force in order to work towards this end, for "democracy will not have a chance unless it is aided from outside - and by force if necessary." (2003: 278) Saddam had proactively crushed any and all internal attempts to oppose and overthrow him (Perle 2000: 103-04). External help from the Americans, as

\footnotetext{
liberators the United States when we come to do that." (Interview transcript quoted in Washington Post June 21, 2005, page A21).

${ }^{9}$ In a letter sent to the Speaker of the House - Newt Gingrich, and the Senate Majority Leader - Trent Lott, a similar point was made: "There is reason to believe ... that the citizens of Iraq are eager for an alternative to Saddam, and that his grip on power is not firm." This letter was signed by a number of people including: Richard Perle, Donald Rumsfeld, and Paul Wolfowitz (PNAC website: May 1998).
} 
well as the Iraqi opposition outside Iraq, was necessary to remove Saddam from rule ${ }^{10}$.

This approach rested on the

... recognition that Saddam Hussein's regime is so discredited, deceptive and dangerous that it no longer can be considered a legitimate government, and that the opposition, which is forced to operate outside Iraq, holds a greater claim to legitimacy. (2000: 108)

Thus, it was America's duty to help the Iraqi opposition, and to "offer freedom to a suffering people" (Frum \& Perle 2003: 167) ${ }^{11}$.

Those who oppose this war believe that the use of force will overshadow the liberation of Iraq. They argue that "coercive democratization" will not work (PNAC website: Schmitt July 2003) ${ }^{12}$. This is not so; freedom and liberty will characterize this war, not violence and destruction:

... the early signs suggest that the president is right to believe that the instinct for liberty is not missing from Middle East genes ... As New York Times correspondent John Burns reported from Baghdad on the eve of the start of the war, 'Iraqis have suffered beyond, I think, the common understanding of the United States from the repression of the past 30 years here. And many, many Iraqis are telling us now, not always in the whispers we have heard in the past but now in quite candid conversations, that they are waiting for America to come and bring them liberty.' And, he said on PBS, 'while they are very, very fearful of course of the bombing, of damage

\footnotetext{
${ }^{10}$ What is being referred to here is the Iraqi National Congress (INC), which is headed by Ahmed Chalabi. The INC was a favorite of the neoconservatives. After the fall of Saddam, many in the movement were upset that the US did not allow the INC to form a provisional government soon thereafter (Frum \& Perle 2003: 165-66).

${ }^{11}$ It is interesting to note that at the time of writing this piece, Richard Perle advocated a solution that inverted the military-political strategy eventually adopted by the Bush administration. His approach argued that a political safe haven be established in northern and southern Iraq for the INC first. Once their political legitimacy expanded among the masses, a military strategy aimed at a forceful removal of Saddam from power in central Iraq would be carried out (Perle 2000: 108)

${ }^{12}$ In this piece, Schmitt reminds the reader of the unethical nature and strategic fallacy of this opposition to 'coercive democratization': “. .. if 'coercive democratization' more broadly means using aggressively all the tools of American statecraft to reform regimes, then, I'm sure the peoples of Poland, South Korea and South Africa are glad they too were not left to the vagaries of neoliberal policymakers. Are the impoverished and tyrannized populations of the Muslim world really going to take comfort in a policy perspective that ... says that 'true success will come only from a long-term effort to help push Arabs to reform their societies from within.' Do neo-liberals really think that this a strategy likely to work with Syria, in Lebanon or with Persian Iran?" (PNAC website: Schmitt July 2003)
} 
to Iraq's infrastructure ... there is also no doubt - no doubt - that there are many, many Iraqis who see what is about to happen here as the moment of liberation.' That's a dream only American power can inspire. (PNAC website: Schmitt March 2003)

This would be proven to Iraqis and the world in the second step of this tactic - the democratization of Iraq,

We did not come to Iraq to stay. Our tasks are to build a new Iraqi army and police force - and fast; to encourage the rapid spread of economic activity and fast; and to get Iraq's oil fields producing again to meet Iraq's needs and likewise fast ${ }^{13}$. But the job of identifying, trying, and punishing the henchmen of the old regime is for Iraqis to do. The job of writing a constitution for their country is theirs as well. We can offer advice ... We did not come to Iraq to govern it. We came to Iraq to restore the selfgovernment stolen from it by decades of tyranny. (Frum \& Perle 2003: 165)

\section{The Re-construction of Iraq - Democratization.}

It is best to begin this discussion with an exploration of the neoconservative view of this process of democratization:

In the Middle East ... Democratization means opening political spaces in which Middle Eastern people can express concrete grievances in ways that bring action to improve their lives. It means creating representative institutions that protect minorities and women in a part of the world where minorities and women very much need protection. It means deregulating the economy to create economic opportunities and also to reduce the government's control over its people's livelihoods. It means shrinking and reforming the Middle Eastern public sector so that it functions honestly and responsively. It means perhaps above all establishing schools that prepare young people for the world of today, not the world of 1,300 years ago. (Frum \& Perle 2003: 162-63)

\footnotetext{
${ }^{13}$ This is important to remember for it shows the American desire to operate in an 'in-and-out' fashion in this mission.
} 
While this list seems large and overwhelming, its proponents argue that it is attainable.

Iraq does not have to achieve all of these goals fully or quickly ${ }^{14}$; this process will take time:

Iraq does not have to attain perfection to challenge the region with the power of a better alternative. If Iraq's new legislature is freely chosen and has means to hold the executive to account, if its bureaucracy is generally honest and competent and its courts are fair, if Iraqis can engage in private business without harassment and favoritism, if Iraq's different communities can live without fear - then that is an achievement as impressive as anything the democratizers could hope for. (2003: 168)

The essential ingredient in the list of objectives above is the establishment of an elected representative government, and a constitution that provides rights to all of the ethnic and religious groups within Iraq $^{15}$. This is the first and indispensable objective that is needed to set in motion this process of democratization. This was a point continuously stressed by the proponents of the discourse,

Our goal would be an Iraq that has territorial integrity, a government that is democratic and pluralistic, a nation where the human rights of every ethnic and religious group are recognized and protected. (PNAC website: Cheney in Kristol August 2001)

Holding free and open elections and establishing a just and democratic constitution are reasonable and reachable objectives. America has done this kind of work before - in

\footnotetext{
${ }^{14}$ In terms of America's strategic interest in spreading democracy in the Middle East, policy-makers should keep in mind that "if the [Iraqis] even partially succeed, they will set off a convulsion in Arab politics." (Frum \& Perle 2003: 164)

${ }^{15}$ This was also evident in official strategic documentations. A document titled "Iraq: Goals, Objectives and Strategy" issued in August of 2002 stated that a main part of its strategy is the necessity "to work with the Iraqi opposition to demonstrate that we are liberating, not invading, Iraq, and give the opposition a role in building a pluralistic and democratic Iraq, including the preparation of a new constitution." A further objective was "to establish a broad-based democratic government that would adhere to international law and respect international norms, that would not threaten its neighbors, that would respect the basic rights of all Iraqis, including women and minorities, that would adhere to the rule of law, including freedom of speech and worship." (Document cited in Woodward 2004: 155)
} 
places such as Europe and East Asia (e.g. Germany, Japan, South Korea) (Frum \& Perle 2003: 163).

In this process, it is important to include Iraqis at every step of the way. The US has no interest in maintaining a visible and heavy presence in Iraq - the goal is to transfer power to Iraqi hands as soon and as fast as possible. This Iraqi involvement should begin with the war itself, and then be carried through to the process of democratization,

Like the forces of the Free French and the Resistance in World War II, the Iraqi opposition would carry the burden of the country's honor. The people of Iraq have been woefully compromised by decades of totalitarian rule. The blood of the Iraqi opposition could give the whole country a much-needed moral reference point. (PNAC website: Gerecht May 2001)

Once the removal of Saddam is secured, the post-war process of reconstruction must be carried out with a heavy Iraqi involvement. This process ought to be guided by a number of principles, the overriding one being the understanding that

Regime change is not an end in itself but a means to an end - the establishment of a peaceful, stable, united, prosperous, and democratic Iraq free of all weapons of mass destruction. We must help build an Iraq that is governed by a pluralistic system representative of all Iraqis and that is fully committed to upholding the rule of law, the rights of all its citizens, and the betterment of all its people. The Iraqi people committed to a democratic future must be integrally involved in this process in order for it to succeed. Such an Iraq will be a force for regional stability rather than conflict and participate in the democratic development of the region. (PNAC website: March 2003) ${ }^{16}$

Another important factor in the reconstruction of Iraq is the inclusion of America's allies, as well as other important members of the international community (even those who opposed this war), in this process. This is important financially and

\footnotetext{
${ }^{16}$ This statement was not signed by any of the important policy-makers (note that previous statements signed by policy-makers were issued at a time when these figures were not in office). It was, however, signed by a number of intellectual figures including: Reuel Marc Gerecht, Robert Kagan, William Kristol, and Gary Schmitt.
} 
politically. The burden will remain heaviest on the US, but others can help in this process and create a better chance of success in Iraq. Ultimately, success in Iraq is good for the whole world, and therefore, many in the international community ought to play a role in re-building the country (PNAC website: March 2003). Finally, it must at all times be remembered that the democratization of Iraq will lead to important transformations in the Middle East ${ }^{17}$. It will create an important question among the masses of the region: "If Iraq can have a representative government, why not Egypt?" or any other Middle Eastern state $^{18}$ (Frum \& Perle 2003: 167).

The successful disarming, rebuilding, and democratic reform of Iraq can contribute decisively to the democratization of the wider Middle East. This is an objective of overriding strategic importance to the United States, as it is to the rest of the international community - and its achievement will require an investment and commitment commensurate with that. (PNAC website: March 2003)

The stability this process would create in the region is of paramount importance to America's strategic interests (Kaplan \& Kristol 2003: 97). It promotes a world that is congenial to American interests and power. The necessity of creating this world became clear after 9/11,

But promoting democracy in the Middle East is not a matter of national egoism. It has become a matter of national well-being, even survival. On September 11, the Arab world's predicament became our own. Not only has Arab repression fueled Islamist terror movements and anti-American extremism; the very regimes we have been propping up have directly encouraged these forces as a way to deflect popular anger from their palace gates. (2003: 101; emphasis added) ${ }^{19}$

\footnotetext{
${ }^{17}$ These important factors are all consistent with the postwar planning within the Bush administration. A list of the administration's objectives as presented by the head of postwar planning, Douglas Feith, is presented in appendix B.

${ }^{18}$ This certainly resembles the famous 'domino theory' of 1954 . However, I did not find any references to this theory within the discourse.

${ }^{19}$ The emphasized section is important to remember for my later discussion of the discourse's two-level thinking.
} 
The neo-conservatives insist that those who doubt America's ability to accomplish this feat in Iraq are wrong for two reasons. First, the anti-democratizers argue that this task of democratization is indicative of a "dangerous utopianism" (2003: 110). This opposition is misled, unethical, and even racist. It is underlined by the idea that Iraqis are unworthy and/or are not capable of achieving, freedom, liberty, and democracy (2003: 100-01; Frum \& Perle 2003: 167). The neoconservative internationalists, on the other hand, believe that all people aspire to freedom and liberty - "To say that [Americans] are engaged in "imposing American values" when we liberate people is to imply that there are peoples on this earth who value their own subjugation." (Frum \& Perle 2003: 277) While some point to the deep-seated corruption and moral backwardness in the Middle East as evidence for the incongruity of Muslim Arabs and democracy, the neoconservatives believe that tyranny is the cause of this corruption and immorality, not Islam or the Muslim Arab world:

... we have seen many times how evil ideas that seemed to hold millions in their grip have yielded to new realities - or been smashed by unexpected defeats. So we must be on the lookout for ways to change the realities of the people now in the grip of extremist Islam, firmly trusting that they too are members of the same human family as are the peoples of all the other nations that have emerged from tyranny to freedom. (2003: 157-58)

The neoconservatives are thus willing to take the necessary actions to ensure that a large part of the world enjoys freedom and liberty.

We do not show our respect for human difference by shrugging indifferently when people somehow different from ourselves are brutalized in body and spirit. If a foreign people lack liberty, it is not because of some misguided act of cultural choice. It is because they have been seized and oppressed and tyrannized. (2003: 277) 
No one should fear American interference in the internal affairs of others. In the case of Iraq, American interference would be welcomed by the masses. Those who object to this approach do not understand the kind of suffering Iraqis are going through - they do not seem to care either. In thinking about matters of outside interference, one must keep in mind the powerful words of Alexandr Solzhenitsyn,

The Communist leaders say, 'Don't interfere in our internal affairs. Let us strangle our citizens in peace and quiet,' ... But I tell you: Interfere more and more. Interfere as much as you can. We beg you to come and interfere. (Quoted in Kaplan \& Kristol 2003: 109)

Second, the anti-democratizers believe that some kind of internal historical processes or developments could alone bring democracy to Iraqi society. They simply want to sit back, and await the emergence of democracy in the Middle East,

The Bush doctrine rejects the complacent assumption that 'engagement' will suffice to promote democratization. It also acknowledges that democracy is a political choice, an act of will. Someone, not something, must create it. (Kaplan \& Kristol 2003: 108)

Democracy had to be constituted in the Middle East. Only the US could take on this task. That is the only way democracy was ever going to emerge in the region (Frum \& Perle 2003: 278). Human action, not 'history', brings about changes and transformations ${ }^{20}$.

\section{The Discourse's Two-Level Thinking and the 'Isolationism-Expansionism' Tension}

This two-step model brings into focus the two features mentioned at the conclusion of Chapter One. The asymmetry of the two-level thinking is best seen in how

\footnotetext{
${ }^{20}$ This is a belief that was fundamental to the formation of neoconservative discourse in the $1960 \mathrm{~s}$. Neoconservatives detested the "abstract social theorizing of liberals", and were clearly in favor of pragmatic social policy that would be described "in terms of achieving explicit moral goals." (Zagacki 1996: 179)
} 
democracy is utilized within the discourse. The argument for spreading democracy is primarily built around a core strategic idea: that once democratic, neither Iraq nor the Middle East would represent a threat to American hegemony and interests; rather, they would represent America's newest allies. This illustrates the view within the discourse that the moral 'good' of this mission is of secondary importance to America's strategic interests. The discourse's architects believe that democracy is good in and of itself, but its strategic use in creating American allies in key regions of the world is the driving force behind their approach towards foreign affairs. In short, while these architects argue that the US ought to follow general moral principles in policy-making, the strategic necessity of certain, immediate situations will ultimately dictate where and when they advocate American intervention in the affairs of others (Wolfowitz 2000: 334-36). Thus, the spread of democracy is not a force of policy-making in its own right. It is not a task that can be pursued on its own, or for its own good. It rather acts as a tool for pursuing America's strategic interests.

This asymmetry can be further seen in the desire expressed within the discourse to ensure that a progressive, Western-friendly candidate win the Iraqi elections. This is clearest in the preference expressed for American involvement in organizing the elections and the establishment of a constitution that forces the new Iraqi government to adhere to Western values such as: human rights, religious freedom, open-markets, respect for diversity, non-proliferation, etc. (PNAC website: March 2003). Through this, the discourse's architects believed that America could avoid what occurred in Algeria in 1995, for instance, when Islamic extremists were brought to power through elections (Frum \& Perle 2003: 162). They simply argued that the surest way of avoiding such an 
undesirable outcome was to allow their favored Iraqi opposition group (INC) to assume provisional power soon after Saddam's fall. This group - a Western-values friendly one (2003: 164; Perle 2000: 103-04) - would immensely help America establish an Iraqi constitution and an electoral process that would ensure the election of a progressive leader who would eventually become an American ally ${ }^{21}$. In short, the neoconservatives wanted democracy in Iraq to follow a specific path of American values; not a path determined by Iraqis alone. This is the only path that is acceptable because it is the only one that would serve America's strategic interests. In other words, if democracy does not satisfy or aid these interests, then it is not worth constituting. In this sense, the moral 'good' of democracy is only beneficial in so far as it serves America's strategic interests. This model also brings into focus the 'isolationism-expansionism' tension. At the core of this tension lies the neoconservatives' 'in-and-out' approach towards foreign affairs. In Colossus, Niall Ferguson argues this very point, when he labels the US as an "empire in denial" (Ferguson 2004: 3-7),

The British and American occupiers both promised they would soon hand over power to Iraqis and leave ${ }^{22}$. The difference is that Americans mean it. They sincerely want to go home ... In short, when the Americans say they come as liberators, not conquerors, they seem to mean it. (2004: 202-03)

For Ferguson, the US falls short of the imperial force he wishes it to be precisely because it refuses to establish and run colonial administrative structures akin to those of the British Empire in the past (2004: 202-14). What Ferguson fails to appreciate, however, is

\footnotetext{
${ }^{21}$ The discourse's architects also believe that given a fair and legitimate chance to elect a leader (i.e. without 'rigged' elections, which are predominant in underdeveloped and developing countries - e.g. previous elections in Egypt, Syria, or Algeria), people of all different cultures would choose a progressive leader who adheres to the principles of freedom and human rights. However, the failure of democracy can still be accounted for and absorbed in this plan. This will be discussed in Chapter Five.

${ }_{22}^{2}$ In reference to the British invasion of Iraq in 1917.
} 
that this discourse is driven by forces different than those of the British Empire ${ }^{23}$. The neoconservatives prefer this 'in-and-out' approach precisely because they do not want to be like the British Empire, or any other past empire for that matter ${ }^{24}$. For the most part, they do not even want to be associated with the word 'empire'. In response to Ron Asmus and Ken Pollack's denunciations of this discourse's "talk" of 'empire', Gary Schmitt writes,

First, 'talking' about empire is a way of suggesting neo-cons want America to be an empire but without actually saying so. And while there has been some loose talk about empire and imperial requirements by some within the neo-con ranks, the reality is, no one is actually suggesting the U.S. assert its permanent sovereignty over foreign lands and peoples to create a real empire. (PNAC website: Schmitt July 2003)

Past Empires only claimed that they were interested in advancing the 'civilizing mission'. In reality, they were only pursuing their own, narrowly defined, self-interests - it was those interests that dictated their presence as colonial powers in foreign lands. For the neoconservatives, the US has no interest in such a project. This is what makes American power unique:

There is a vital distinction between being powerful - even most powerful in the world - and being an empire ... America is not an empire, and its power stems from voluntary associations and alliances. American hegemony is relatively well accepted because people all over the world know that U.S. forces will eventually withdraw from the occupied territories ... Contrary to the exploitative purposes of the British, the American intentions of spreading democracy and individual rights are incompatible with the notion of an empire ... the United States has always made money for its partners.

\footnotetext{
${ }^{23} \mathrm{He}$ is indeed fully aware of these forces, as he goes through great lengths in the first part of his book to lay them out (2004: 33-166).

${ }^{24}$ This is a point that Ferguson quickly refutes, or brushes aside, in the beginning of his book: "To those who would still insist on American "exceptionalism," the historian of empires can only retort: as exceptional as all the other sixty-nine empires." (2004: 15) While this may be true - that is, while all other empires may have also believed themselves to be exceptional - I do not believe that this raises solid grounds for dismissing this feature or characteristic of empire from the analysis. If anything, it makes it more pertinent. In this case, American exceptionalism is clearly an integral part of this discourse, and it plays an important role in the development of the plan in question here.
} 
America has not turned countries in which it intervened into deserts; it enriched them. (PNAC website: Kagan R. in Schmitt July 2003)

This assertion of American power is primarily driven by the isolationist elements of the discourse: to enhance and sustain American security (i.e. to maintain a healthy distance from the world's dangers), and American sovereignty (i.e. the ability to choose domestic policies in spite of the rest of the world - or more properly, in spite of an international system ${ }^{25}$ ). Erecting colonial administrative structures could not, and would not, satisfy these goals. Such an approach would only entangle the US deeper and deeper into the affairs of others; thus making Americans more vulnerable to attacks at home and abroad, as well as forcing the US to have to consider its colonial administrations (and hence the affairs of foreign peoples) in its national policy-making decisions.

Conversely, of course, the US could not act in a completely isolationist manner: it could not simply pursue its own well-being without paying some attention to the outside world ${ }^{26}$. It could not sit back and hope that the threats to its hegemony, security, and sovereignty would simply disappear on their own. It must exert its power to ensure that such threats are defeated. Simply put, to maintain sovereignty and security, an aggressive tool was necessary. Since history had shown the US that democracies simply do not fight wars with each other - that they do not create the hate and destruction found in militant Islam - the solution to the US predicament was clear: spread democracy and fast. The fastest method for this solution was also clear: war.

War can create a situation in which change and transformation become 'easier' and faster to introduce and implement. Once democracy is introduced to the region, the

\footnotetext{
${ }^{25}$ The relationship between foreign and domestic policies was discussed earlier (see pp. 37-38, and 49-54).

${ }^{26}$ The Ancient Egyptians arguably represent the closest historically-known example of an empire behaving in such a manner (Wright 2004: 85, 103-04).
} 
US can pull-out and maintain a healthy distance from $\mathrm{it}^{27}$. In this process of constituting democracy, Iraqis would have to play a major part in this transformation. This would further ensure that American influence and presence in the region would slowly, but surely, subside over the years. The two-step plan is that simple: war is the tool for expansion; political reconstruction is the tool for isolation.

The perceived necessity for constituting democracy abroad, and fast, within this discourse led to the utilization of war as a means toward a political end. Essentially, war only became necessary once the quick constitution of democracy abroad became necessary. In other words, this is not a war of necessity in the sense that the hand they were dealt absolutely forced them to play this card; it was a war of necessity in the sense that the hand they chose to play forced them to play this card. War, therefore, plays a subordinate role to politics in the sense that politics, not war, would form the decisive solution to the American predicament with the Middle East. If the discourse's ideas regarding American superiority and its 'good vs. evil' thinking made it more likely to choose the path of military force (see pp. 51-52), it was the need to find a fast solution to this predicament that facilitated the use of war in the plan. When these two forces combined, they fueled the Clausewitzian view of war that is pertinent in the discourse ${ }^{28}$.

This raises an important question: since it relies on this Clausewitzian view of war, will this discourse have to then face the same problem with which Clausewitz struggled and, in my view, never really overcame? That being, how do you account for

\footnotetext{
${ }^{27}$ Pulling-out does not entail the outright removal of American forces from Iraq or the region. It only entails the removal of American forces from the streets of Iraq - where the process of ensuring the day-today security of Iraqis can be transferred over to an Iraqi security force. Similar to Japan and Germany, American military bases would most likely maintain a presence in Iraq for a long period to come (Kagan R. 2003: 93).

${ }^{28}$ Ferguson also believes that the invasion of Iraq made Clausewitz one of the 'winners' of the war (2004: 163).
} 
resistance $?^{29}$ How do you know when the war really ends, and when politics begin? Moreover, if you stuff the process of political reconstruction down the throat of the resistance in order to eliminate $\mathrm{it}^{30}$, then are you not admitting that politics is the continuation of war by other means? Addressing these questions will have to precede my critical reflection on the discourse surrounding its two features: two-level thinking, and the tension of 'isolationism-expansionism'.

Section II will thus begin with an examination of the theoretical work of Clausewitz, and the relationship between war and politics.

\footnotetext{
${ }^{29}$ The admissions some in this discourse have made about this very point will be discussed in the next section when it is more appropriate.

${ }^{30}$ In the next section, this point will be supported by quotes from the discourse.
} 


\section{SECTION TWO}




\section{Chapter Three}

\section{'War and Politics: An Inquiry into Clausewitz'}

This chapter outlines the paradox at the core of Clausewitz's classic On War. Understanding this paradox partially relies on an understanding of Foucault's discussion on war and resistance. Thus, I begin with an examination of Foucault's two schemata for the analysis of power. It should be noted that the following discussion is only interested in politics in so far as it relates to war. Therefore, a sophisticated or comprehensive conception of politics per se will not be presented or used.

\section{Foucault's Schemata for the Analysis of Power}

\section{War-Repression:}

In Society Must Be Defended Foucault embarks upon the task of formulating a schema for the analysis of power. The first schema he puts forth is 'war-repression' (Foucault 2003: 17). He defines repression as "the effect and the continuation of a relationship of domination ... the implementation, within a pseudopeace that is being undermined by a continuous war, of a perpetual relationship of force." (2003: 17) War is simply defined as "the clash between forces" by means of weapons and battles (2003: 18). In this schema, war acts as a 'principle of intelligibility' rather than a 'disruptive principle' in our understanding of power, law, and the state (2003: 163).

The most important feature of this schema is that it focuses on the opposition between two sides as it takes place within the context of 'struggle and submission' (2003: 
17). In this context, the relations of domination (characteristic of any opposition between two sides) are fought over in the battlefields of history (2003: 46). The interplay of forces during battle arise out of already existing relations of domination, and is meant to either re-affirm such relations, invert them, or to establish new ones (2003: 160). Essentially, such interplays can help us understand and explain the relations of domination within the state. This approach basically objects to the theory of sovereignty, and argues that The law is not born of nature, and it was not born near the fountains that the first shepherds frequented: the law is born of real battles, victories, massacres, and conquests which can be dated and which have their horrific heroes; the law was born in burning towns and ravaged fields. It was born together with the famous innocents who died at break of day ... Law is not pacification, for beneath the law, war continues to rage in all the mechanisms of power ... War is the motor behind institutions and order. (2003: 50)

Through its focus on "the contingency and injustice of battles", this schema aims to highlight the contingent element of power (2003: 72). It brings forth the idea that the legitimacy of the rulers, or of those who dominate the state (whether it be kings, queens, elites, parliaments, or presidents), is born of their unjust victory on the battlefield. The analysis here is essentially based on a binary schema:

The social body is not made up of a pyramid of orders or of a hierarchy, and it does not constitute a coherent and unitary organism. It is composed of two groups, and they are not only quite distinct, but also in conflict. And the conflictual relationship that exists between the two groups that constitute the social body and shapes the State is in fact one of war, of permanent warfare. The State is nothing more than the way that the war between the two groups in question continues to be waged in apparently peaceful forms. (2003: 88)

The victors on the battlefield become the main beneficiary of the relations of domination born of war. The victors dictate the shape, effects, and direction of this relation ${ }^{1}$. Simply

\footnotetext{
${ }^{1}$ The question of 'resistance' will be discussed later in the chapter.
} 
put, war becomes the basis upon which the very definition of the "principles of public right' rests (2003: 124). Now, in order for the victors to preserve and enhance their position of dominance born of war, a political project - a more indirect method of dominance - is needed. This leads us to the next schema.

\section{Contract-Oppression:}

The second schema available for the analysis of power is 'contract-oppression'. This schema primarily rests on the theory of sovereignty. Its main concern is to analyze the abuse of power - the instances, institutions, and mechanisms whereby the state oversteps its limits, abuses its power, and uses it as an oppressive tool against its subjects (Foucault 2003: 17). Rather than 'struggle-submission', the opposition between two sides here resides between "the legitimate and illegitimate" apparatuses, forms, and mechanisms of governance (2003: 17). In this case, oppression refers to the "transgression of the limit" by the sovereign; whereas contract is the "matrix of political power" whereby the sovereign gains its legitimacy through the willful surrender of power by the individual (2003: 17).

As a result of its focus on the contract, this schema forms a fundamentally different view of war than the previous one. War, here, is not only an activity which involves weapons and real battles; rather, it is part of a larger and continuous 'state of war'. It is this state of war that ought to be our main concern, not the real battles of history (2003: 92). This state of war is primarily characterized by an "unending diplomacy between rivals who are naturally equal" (2003: 92) during peace time as well as war time - the result of which is an unending state of war where life is always 
threatened by death. The contract acts as a shield against this permanent state of war, and it can be acquired through one of two mechanisms: 'institution' or 'acquisition' (2003: 93). Very briefly, institution entails the granting of individual rights to a sovereign who then becomes the protector and representative of the surrendering individual; whereas acquisition deals with the establishment of a sovereign on the basis of "relations of force that are at once real, historical, and immediate" - i.e. on the basis of "a real battle" (2003: 93-94). Regardless of the mechanism, however, the contract is always established on the basis of a relationship of sovereignty - one characterized by the series of "will, fear, and sovereignty." (2003: 96)

The latter point is a peculiar one, particularly when one is speaking of a mechanism of acquisition. Foucault's question surrounding this mechanism provides us with a telling insight concerning this schema. He asks: how is it possible to view this mechanism as indicative of a relationship of sovereignty, and not domination? If an actual battle dictated that a victorious foreign sovereign rules over a defeated people (people whose lives were spared during battle), then how is this relationship one of sovereignty and not the continuous domination of the victors over the vanquished? The answer this schema advances is:

Because once the defeated have shown a preference for life and obedience, they make their victors their representatives and restore a sovereign to replace the one who was killed in the war. It is therefore not the defeat that leads to the brutal and illegal establishment of a society based upon domination, slavery, and servitude; it is what happens during the defeat, or even after the battle, even after the defeat, and in a way independently of it. It is fear, the renunciation of fear, and the renunciation of the risk of death. It is this that introduces us into the order of sovereignty and into a juridical regime: that of absolute power. The will to prefer life to death: that is what founds sovereignty, and it is as juridical and legitimate as the sovereignty that was established through the mode of institution and mutual agreement. (Foucault 2003: 95) 
In other words, the creation of the state, regardless of the mechanism of its founding, is always legitimate. The programmatic is to then move forward, away from the sites of real battles, and realize the state's 'just' form (2003: 110-11). In short, this schema is concerned with the capacities and potentialities of the state - in other words, with the present and the future respectively (2003: 222). It is concerned, not with revolution and/or the re-constitution of the state, but rather with the ability of individuals to constitute a state - with the universality of the state (2003: 223-24). War, thus, is no more than the battles which had finally led us to the universal and just totality of the state - and this state explains history, not war (2003: 233-36).

\section{The Connection between the Schemata:}

Foucault's discussion on the strategic utility of these two schemata provides us with an important insight into the connection between them. These strategic utilities are simple enough. 'Contract-oppression' aims to hide the battles of the past and, thus, solidify the legitimacy of the social orders established through these battles. 'Warrepression', on the other hand, aims to re-awaken the history of these past battles and, thus, the injustices and the illegitimacy of the social orders established through them (Foucault 2003: 57-58, 98-99, 110-111).

Foucault clearly prefers the 'war-repression' schema for the analysis of power. For him, the resistance that is born of war never stops. It must, therefore, be continuously crushed by political means - means that, first and foremost, are meant to preserve the relations of domination born of war. Resistance here cannot be judged on a short timeline. It goes through peaks and valleys in ferocity and intensity - it can even fully 
terminate for a period of time, only to be resurrected at a later point in history. This is what Foucault was driving at in Society Must Be Defended. A good summary of this point (and the interplay between the two strategic utilities) is given when he is discussing the Saxon-Norman struggle,

What the Levellers will say is this: "The monarchy is perfectly right to say that the invasion, defeat, and Conquest did take place. It's true, the Conquest did take place, and that has to be our starting point. But the absolute monarchy interprets the fact that the Conquest took place as providing a legitimate basis for its right. We, on the other hand, interpret the fact that the Conquest did take place, and that the Saxons really were defeated by the Normans, as meaning that the defeat marked, not the beginnings of right absolute right - but of a state of nonright that invalidates all the laws and social differences that distinguish the aristocracy, the property regime, and so on." (2003: 107)

What is crucial here is the idea that the relations of domination established through war do not simply terminate when the political end or project is initiated and fully underway (although that is precisely what the 'contract-oppression' schema attempts to accomplish and what the 'war-repression' schema aims to re-awaken). Rather, these relations of domination will continue to shape and influence the political project: the forms it takes, its tensions, and the struggle over its future directions.

Humanity does not gradually progress from combat to combat until it arrives at universal reciprocity, where the rule of law finally replaces warfare; humanity installs each of its violences in a system of rules and thus proceeds from domination to domination. (Foucault 1977: 151)

To conclude, the point I wish to highlight here is that while each schema aims to dissociate itself from the other strategically, they are connected in the sense that they are both concerned with the relationship between war and the politics following it. More specifically, they are concerned with the relations of domination operating within this 
relationship of war and politics. The main difference between them is that one schema aims to preserve these relations, the other aims to overthrow them. As a result, each schema ends up focusing on a different aspect of this little understood relationship between war and politics. This connection will therefore serve as the basis for understanding the paradox I wish to highlight next. By relying on Foucault's argument concerning the connection between the two schemata, however, I will not go as far as utilizing the strategic use that Foucault outlines for 'war-repression'. I am not concerned with a re-awakening of past battles and orders, or with the totality of the present and the potentiality of the future for that matter. I am concerned with the relations of domination that are at work during struggles which revolve around a war-politics relationship, and what those relations of domination mean for the neoconservative project in question. Putting aside this difference in strategic utility then, I examine, next, how these two schemata can help us understand the Clausewitzian paradox, and ultimately the two-step plan in question.

\section{Clausewitz's On War and the Question of Resistance}

In light of the war-politics relationship of interest here, Foucault's schemata can be summed up: 'war-repression' involves the view of 'politics as a continuation of war by other means', and 'contract-oppression' involves the view of 'war as a continuation of politics by other means' ${ }^{2}$. Clausewitz is the author who made the latter quote famous ${ }^{3}$. His discussion of war in a 'means-ends' context with politics has drawn the most

\footnotetext{
${ }^{2}$ Foucault refers to Clausewitz in this manner in his work (2003). I am not sure that he would use the term 'summed up', but it is not overly presumptuous to assume so.

${ }^{3}$ While Clausewitz coined the phrase, the idea itself could be inferred from the works of previous intellectuals and military theorists such as Mahan, Jomini, and Machiavelli (Bassford 1994: 152).
} 
academic attention to his impressive work ${ }^{4}$. My own discussion of him will revolve around this point as well.

For Clausewitz (orig. 1832), war has three dimensions that must at all times be kept in sight. War is "composed of the original violence of its essence ... the play of probabilities and chance ... and of the subordinate character of a political tool" (Clausewitz 1943: 282). The first dimension belongs to the province of the people, the second to the army and its commanders, and the third to that of the government. For my purposes, the first two dimensions can be discussed together under the heading of war as a thing in and of itself ${ }^{5}$. The most important unifying element for the first two dimensions is the idea "that war is an activity of the will exerted not, like the mechanical arts, upon dead matter, nor, like the human mind and emotions, in the fine arts, upon a living, but still passive and yielding object, but upon a living and reacting object." (1943: 357) In other words, the first two dimensions both belong to the province of the human will, where war takes on a life of its own - it becomes its own activity. Within this activity, a set of means and ends exists. At the point of its initiation, this set is separate from, and even outside, the influence of the view of war as a means to a political end (i.e. outside

\footnotetext{
${ }^{4}$ It is important to note that the distinction between 'politics' and 'policy' in the English language does not exist in German, which uses only the word Politik. Thus, when Clausewitz refers to policy or politics, what he meant to say was "that war was an extension of foreign policy in elite-dominated political systems", as opposed to "'internal' matters ... of mass political contention." (Roxborough 1994: 627) 5 This can be justified on the following basis: Clausewitz's defining feature for the first dimension is "the hate and enmity which are to be regarded as a blind, natural impulse", and for the second dimension "a free activity of the emotions" exercised by military commanders and soldiers (1943: 282; also see pp. 264-71, 276-79, 302-14, 340-45 for a more detailed discussion of these two dimensions). Therefore, both dimensions highlight the character of war as an activity in and of itself - one that is mainly characterized by human emotions and moral values, as well as an unpredictable and free-flowing movement of actions and reactions. Where the two dimensions differ is in their sphere of applicability. The first is more concerned with the initiation of hostility among the two peoples involved, the second with the military commanders on the battlefield. This is important for Clausewitz because his work is very much a lesson in military tactics and strategy as it is an attempt at a theoretical understanding of war. Since the former point is of no importance for my purposes, I can simply focus on what these two dimensions share, and not concern myself with their differences.
} 
the influence of the third dimension of war - a state-centered one). Thus far, then, we have two sets of means and ends. Clausewitz further complicates his analysis of means and ends by discussing them in two more categories. We are thus left with four categories: the first deals with war as an activity in and of itself, the second with the tactics of war, the third with the strategies of war, and the fourth with war as a subordinate tool to politics ${ }^{6}$. The second and third categories can be omitted here because they are more concerned with the practical application of Clausewitz's work on the battlefield than they are with his concern with the theory of war $^{7}$. They simply represent a more nuanced discussion on the first and fourth categories respectively. Therefore, I will only discuss one and four here.

Clausewitz defines war as "an act of force to compel our adversary to do our will" (1943: 264). In this activity, "physical force ... is thus the means; to impose our will upon the enemy is the object." (1943: 265) The application of this physical force in war has no limits. Both sides will exert maximum and absolute force in order to compel the other to do their will (1943: 266). The application of force is thus reciprocal - my utmost exertion of force forces my enemy to respond with the same maximum exertion - "So long as I have not overthrown my adversary I must fear that he may overthrow me. I am no longer my own master, but he forces my hand as I force his." (1943: 267) This interplay will continue until the end inherent to this logic is reached. This end entails the physical

\footnotetext{
${ }^{6}$ These can be briefly defined as: "tactics teaches the use of the armed forces in engagements, and strategy the use of engagements to attain the object of war." (1943: 330; original emphasis)

${ }^{7}$ I say this with a certain degree of reservation. Clausewitz states that a theory of war is not meant to, and indeed cannot, act as a guide to a commander on the battlefield - one that can be strictly followed. It rather acts to "guide him in his self-instruction", so that "each person need not have to clear the ground and toil through it afresh, but may find it cleared and put in order." (1943: 346) So, while the discussion I am referring to above is more concerned with the practicalities of war, it is also directed towards the creation of a better understanding of the theory of war Clausewitz is developing, as opposed to a strict 'how to' guide for military commanders.
} 
removal of all of the enemy's forces and its sources of resistance. More specifically, this

end can only be reached when three conditions are satisfied:

The military forces must be destroyed, that is to say, put into such a condition that they can no longer continue to fight ... The country must be conquered, for from the country fresh military forces could be raised. But even if both these things have been done, the war, that is to say the hostile tension and the activity of hostile agencies, cannot be regarded as ended so long as the will of the enemy is not subdued also, that is, until his government and his allies have been induced to sign a peace or his people to submit. (1943: 283-84)

For Clausewitz, however, this absolute end is never reached or achieved in actual warfare, for war is always a 'continuation of politics by other means'. Simply put, the object of 'imposing our will upon the enemy' is a "political act" (1943: 279):

The law of the extreme, the intention of disarming the enemy and overthrowing him, had up to now, so to speak, more or less swallowed it up. As this law loses its force, and this intention falls short of its aim, the political object of the war once more comes to the front. (1943: 271)

The political object of war permeates its existence: it is what initiates, drives, and ultimately ends war (1943: 280). Thus, the most important 'means-ends' discussion for Clausewitz is that which places war as a means and politics as the end. Having said that, it is important to keep in sight the absolute conception of war briefly discussed here. War's volatility and its violent character means that the relationship between means and ends in this context is far from static,

The more [war] will be concerned with the destruction of the enemy, the more closely the military aim and the political object coincide, and the more purely military, and the less political, war seems to be. But the weaker the motives and the tensions, the less will the natural tendency of the military element, the tendency to violence, coincide with the directives of policy; the more, therefore, must war be diverted from its natural tendency, the greater is the difference between the political object and the aim of an ideal war, and the more does war seem to become political. (1943: 280) 
This fluid relationship means that there exists diversity in the character of different wars.

What unites them, however, is that they are always used as an instrument for political ends (even if the political end is not, or does not coincide with, the complete destruction of an enemy's forces) ${ }^{8}$. These political ends are characterized by two simple enough outcomes: the victors and the vanquished ${ }^{9}$. This relationship of victors-vanquished is born of war. In it

We find ... that the vanquished sinks much further below the original line of equilibrium than the victor rises above it ... The main battle takes place for its own sake, for the sake of the victory which it is to give ... Here, on this spot, in this very hour, to conquer the enemy is the purpose in which all the threads of the plan of the war converge, in which all distant hopes, all vague conceptions of the future meet; fate steps in before us to give an answer to our bold question. (1943: 488; emphasis added)

What is this bold question that the battle answers for us? It is the question of domination - of who dominates whom: "It is the evident truth that the enemy is superior to us, a truth which might originally have been so hidden that it could not before be perceived, but which always comes out clear and conclusive in the issue." (1943: 489) Once this question is answered, it "can never be refused, and that, therefore, a belligerent who

\footnotetext{
${ }^{8}$ Having said that, Clausewitz believed the 'destruction of the enemy's forces' contained the greatest value and efficacy for achieving any political objectives. Its high price and expense (in human and material terms) is the main reason why other, less absolute, military methods are employed (1943: 292-93). Even then, however, it will always permeate all and any kind of military action: "we cannot avoid showing here at once that the bloody solution of the crisis, the effort to destroy the enemy's force, is the first-born son of war." (1943: 295)

${ }^{9}$ At this point, one may be tempted to say: 'if this is so, then the discourse in question here is not Clausewitzian. Clausewitz sees victory as the end of war; the discourse sees the propagation of peace as the end of war. Therefore the two views are incompatible.' My response is that this is only so at first sight. During the first half of the $20^{\text {th }}$ century, Basil Liddell Hart and J.F.C. Fuller used this very argument as their point of departure from, and rejection of, Clausewitz. This attempt failed however. It overlooked the fact that Clausewitz never lost sight of the larger political object that was, in most cases, inextricably tied to the propagation of peace - i.e. victory only enabled the victor to pursue this peace. While these men, and others, have attempted to separate themselves from Clausewitz's 'means-ends' discussion, their own formulations of 'means-ends' never surmounted to anything more than a re-wording of Clausewitz's model - one that neither added anything new nor matched the sophistication of Clausewitz's formulations (Spenser Wilkinson (1927) and Michael Howard (1956) are but two of the influential scholars making this point) (Bassford 1994: 128-43).
} 
proposes to take another way must be sure that his opponent [the victor] will not make this appeal, or he will lose his case before this supreme tribunal" (1943: 295). War is thus used in all of its different forms to definitively answer this political question for us.

To sum up: Clausewitz develops a general framework which asserts that war is the means and politics the end. But he also wants to argue that war has means and ends in and of itself. His way out of this apparent contradiction was to argue that the end internal to war terminates when politics take over, and politics always takes over. This leads to a conception of war that is different from his previous absolute one. The new conception involves the view that "war is only a part of political intercourse, therefore by no means an independent thing in itself." (1943: 933; original emphasis) In this conception, war has ... its own grammar, but not its own logic ... policy makes out of the alloverpowering element of war a mere instrument, out of the fearsome battlesword, which should be lifted with both hands and the whole power of the body to strike once and not more, a light, handy dagger, which is even sometimes nothing more than a rapier, which it uses in turn for thrusts, feints and parries. (1943: 934; emphasis added)

Even in this conception, however, Clausewitz still admits that policy can misuse warthat when "policy promises itself a wrong effect from certain military means and measures, an effect opposed to their nature, that it can exercise a harmful effect on war by the course it prescribes ... policy will often order things which do not correspond to its own intentions." (1943: 937; emphasis added) In other words, the absolute conception of war always remains a significant factor, and it can have dire consequences on policy if misused. 
The point I wish to highlight here is simple: Clausewitz cannot overcome this contradiction between his two conceptions of war throughout his work ${ }^{10}$. Perhaps this concluding remark on the issue by Clausewitz will clarify this further:

Therefore, once more: war is an instrument of policy; it must necessarily bear the character of policy; it must measure with policy's measure. The conduct of war, in its great outlines, is, therefore, policy itself, which takes up the sword in place of the pen, but does not on that account cease to think according to its own laws. (1943: 939; emphasis added)

The italicized sections in these quotes highlight the paradox I am interested in here. How is it possible for an instrument that has its own laws, logic (rather than grammar) ${ }^{11}$, and its own means and ends always be subordinate to a higher objective? Moreover, what occurs when this higher objective - politics - misuses the instrument of war? ${ }^{12}$ According to Clausewitz, this will have dire consequences for war and policy. Does this not make war an element presiding over a reciprocal relationship with politics, rather than its subordinate? In other words, is not something that is 'all-overpowering' capable of influencing politics as much as politics is capable of influencing war? Clausewitz says no, it cannot ${ }^{13}$ - why? Because "real war is no such effort tending to the last extreme ... but a half-hearted thing, a contradiction in itself; that, as such, it cannot follow its own

\footnotetext{
${ }^{10}$ W.B. Gallie documents the contradictory elements of Clausewitz's work in terms of their philosophical and logical inconsistencies. His focus is on Clausewitz's conceptions of war - 'Absolute War' and 'Real War' - and on how Clausewitz's use of these conceptions lacks logical consistency. He makes the important point, however, that we should not forget that Clausewitz did not fully revise his work (certain areas were not revised at all), and that these inconsistencies should not lead us to reject Clausewitz, but rather to attempt a reconstruction of his work (Gallie 1978: 48-54). I fully endorse the latter statement, and I do not intend for my reflections on Clausewitz to be, in any way, a complete rejection of his ideas.

${ }^{11}$ Much of Clausewitz's earlier discussion about war suggests that he views war as having its own logic (see footnote 5 for citations). Gallie, along with other Clausewitz commentators (e.g. Roxborough 1994: 623), also make this point (Gallie 1978: 52).

${ }^{12}$ I limit my definition of politics and policy to that of Clausewitz's (see footnote 4). My interest in politics is limited to its relationship with war. This is especially compatible with my case study, as the discourse of interest here, particularly the Straussian influence on it (Lilla 2004: 58), adheres to that type of definition. ${ }^{13}$ Overall, he says no, but here he partially concedes to this point: "the original political intentions change very much in the course of the war and may at last become totally different, just because they are partly determined by the successes and by the probable results [of war]." (1943: 286)
} 
laws, but must be looked upon as part of another whole - and this whole is policy."

(1943: 934) Put differently, war can never reach its absolute end; the enemy can never be completely exterminated. However, if this is so, then does not that mean that the struggle of war does not really end with the initiation of the political object? If the vanquished is only partly defeated, its forces not completely destroyed, and its resistance potentially indeterminate and theoretically infinite, then does not the 'main battle' only provide us with a transitory answer to our 'bold question'? If the struggle of war continues on, and cannot be given a definitive end (because this end, according to Clausewitz, can never be achieved), then is this not more reason to view war as presiding on equilibrium with politics? ${ }^{14}$ Is it not possible for war (which is a thing in and of itself - i.e. the absolute war that Clausewitz went through so much toil to describe) to take human action, or more properly, human intention, down a path not foreseen? Could not the ferocious conflict and violence of this path overshadow, if not replace, the political projects this most volatile and untamable of instruments was meant to achieve? An examination of Clausewitz's discussion on resistance will help to further develop this point.

According to Clausewitz, when two sides confront each other in war, it is very difficult for them to determine the degree of resistance (in ferocity and duration) the other side will bring forth. Such knowledge is not, and cannot, be based on any kind of

\footnotetext{
${ }^{14}$ In footnote 10, I mentioned that Gallie advocated a reconstruction of Clausewitz's work. His attempt, brief as it was, entailed the view of Clausewitz's conceptions of war as comprising two distinct kinds of warfare: 'Absolute War' as a war of high intensity aimed to gain a 'knockout blow' - e.g. the Napoleonic Wars (a point Clausewitz himself makes); and the more common 'Real War' as a war of lower intensity aimed to gain 'any available advantage' - e.g. a game of 'realpolitik', or 'limited war' (Gallie 1978: 5660 ). This reconstruction essentially drops the former conception of war, and adopts the latter for a neoClausewitzian analysis of war. Indeed, this concept of 'limited war' has had much influence on Americanstyle neo-Clausewitzian analysis and thinking, most notably in the works of Robert E. Osgood (1957) and Ned Lebow (1988) (Bassford 1994: 201-02). While insightful and thought provoking in its own right, this approach reconstructs Clausewitz by omitting what is inconvenient to absorb (i.e. 'absolute war', or as I prefer 'war as a thing in and of itself' - just as Liddell Hart and Fuller had done, but for different purposes (see footnote 9)). I believe it is important to maintain in sight both of Clausewitz's conceptions of war, or at the very least the important elements of each.
} 
scientific or mathematical formula. Its estimation rather belongs to a sphere of possibilities and non-statistical probabilities, of quick and immediate judgments and decisions, of emotions, moral values, ambition, and courage - in short, it belongs to a sphere that is volatile, unpredictable, and highly malleable (1943: $355-57)$. Determining the abilities and capabilities of the enemy will always be a difficult undertaking, and it will largely be left to the skills of the commander, particularly the commander-in-chief, to make the right judgments at the right time over such matters:

In order to ascertain what amount of means we have to call up for the war, we must consider the political object both on our own side and on that of the enemy; we must consider the power and conditions of the enemy's state, as well as of our own; we must consider the character of the enemy's government and of his people, and the capacities of both ... That the determination of these diverse circumstances and their diverse connections is an immense problem, that it is a true flash of genius which, confronted with them, quickly picks out the right course, while it would be quite impossible to become master of their complexity by mere academic study, is easily understood. (1943: 909)

In short, resistance is not something that can be mathematically quantified or precisely estimated. It requires a certain degree of human ingenuity and luck to effectively deal with it. An example of this can be seen when we examine a struggle between a strong and a weak side. One of the most likely military methods we will encounter in such a struggle is the prolongation of the fight by the weak - a method aimed at "the tiring out of the enemy" $(1943: 288)^{15}$. In this method (and particularly when it succeeds), it is clear that the resistance was underestimated by the strong. This method also illustrates the point that the absolute end of war was not necessary for the weak to achieve their objectives in war (i.e. survival as a sovereign political entity):

\footnotetext{
${ }^{15}$ It is interesting to note that Clausewitz was among the first to recognize the development of guerilla warfare (Gallie 1978: 65).
} 
We see then that there are many ways to our object in war; that the defeat of the enemy is not in every case necessarily involved; that the destruction of the enemy's military forces, the conquest of enemy provinces, the mere occupation, the mere invasion of them, enterprises aimed directly at political relations, and lastly a passive expectation of the enemy's onset - that all these are means which, each in itself, may be used to subdue the enemy's will, according as the peculiar circumstances of the case lead us to expect more from the one or the other. We can still add to these a whole class of objects, as shorter ways of gaining our aim, which we might call arguments ad hominem ... Including these, we may say that the number of possible ways of attaining the object in view rises to infinity. (1943: 289)

There are three points I wish to highlight from this brief discussion of resistance.

The first is that resistance is not something that can be definitively defined as being exterminated or even suppressed - for how can the victors claim the definitive eradication of something they could not estimate in size, intensity, and ferocity beforehand? Second, the timeline by which a strong and a weak side judge military success is quite different - winning the main battle may indicate the end of the war for the strong, but it may be just the beginning of a prolonged battle for the weak. Third, these two peculiarities of resistance mean that it is very difficult to determine when war ends, and when politics begin - and even visa versa. If we wish to capture the complexities of struggles, one that discusses them without simply regurgitating the history of the victors, then we must emphasize this volatile and malleable element of war. We must pay attention to the relations of domination that are fought over in the battlefields of history. These relations have no clear end, for war has no clear end. Throughout its duration, this 'all-overpowering' violent struggle could very well come to dictate, shape, and re-formulate the initial political project that was so daring to wield the 'fearsome battle-sword'. 
For all their shortcomings, Berger and Luckmann taught us one important lesson: that "Man is capable paradoxically of producing a reality that denies him." (Berger \& Luckmann 1966: 83) In other words, human beings are capable, regardless of their intentions, to produce a reality that comes back to act upon them in ways that are detrimental to them and their intentions ${ }^{16}$. If an unforeseen prolonged war does not fit into such a category, I am not sure what does. On the grounds of these three points, I reject the hypothesis that war always holds a subordinate role to politics - particularly when one is speaking of a war between a strong and a weak side.

To conclude this discussion on Clausewitz, I do not believe that he ever intended for his conception of absolute war to be discussed only so that it could be abandoned at a later point. He intended to bring it from the darkness and out into the light for all of us to see and discuss. He did, however, attempt to subordinate this conception to one of war as a tool for politics. This attempt failed, and I disagree with Ian Roxborough's solution to this problem:

His attempted resolution of the contradiction between a notion of war as unlimited violence and war as an extension of politics is unconvincing; modern readers must opt for one or other of the definitions. This article rejects Clausewitz's early formulation in favour of the mature definition of war as an extension of politics by other means as the first step towards creating a neo-Clausewitzian sociology of war. (Roxborough 1994: 624)

Roxborough and many others rightly argue that Clausewitz's conception of war as an instrument of politics challenges his conception of war as a thing in and of itself. But what I have argued here is that, conversely, Clausewitz's conception of war as a thing in and of itself challenges his conception of war as an instrument of politics. This latter

\footnotetext{
${ }^{16}$ The issue of 'intention' and war, particularly of 'good intention', will be discussed in Chapter Five with reference to the work of Carl Schmitt.
} 
point is of immense importance in any analysis of a plan that attempts to subordinate war to politics.

\section{Domination \& Legitimacy}

Does this mean that politics is the continuation of war by other means? My answer is that it is irrelevant and futile to enter into a debate concerning which precedes which - war or politics. This debate essentially attempts to either subordinate politics to war or war to politics. I wish to discuss war and the political project on an equal level as two equal contexts which bring to our attention that which lies at the core of each: the relations of domination, and the legitimacy which allows the dominant force to claim that position of dominance. If we focus the analysis on these relations and their legitimacy, we can then discuss the peculiarities of a war-politics relationship without having to subordinate one to the other. This will hopefully highlight their interconnectedness, as well as the analytical advantage of including both in examining this particular case. Ultimately, this is meant to critically examine the 'in-and-out' thinking underlying the neoconservative approach towards the Iraq War.

Why do I use the term domination and how does it relate to legitimacy $?^{17}$ As Clausewitz has argued, the ferocity of battle always produces a political outcome that is based on domination (it is this part of Clausewitz's work that I refuse to abandon). In other words, war produces a relationship of coercion and resistance - of domination. I reject the idea that these relations disappear with the end of war when examining the

\footnotetext{
${ }^{17}$ For space and time limitations, I cannot delve into all of the sociological, philosophical, and political debates surrounding these concepts. I will only address them in so far as they are significant for our understanding of war and the political project following it.
} 
struggle between a strong and a weak side. This is due to the aforementioned difficulty in establishing the end of war in such a struggle.

The methods by which legitimacy is established in such relations of domination are of immense importance, for such methods highlight the interconnectedness of war and the political project following it. I take Jürgen Habermas's definition of legitimacy as my starting point:

Legitimacy means that there are good arguments for a political order's claim to be recognized as right and just; a legitimate order deserves recognition. Legitimacy means a political order's worthiness to be recognized. This definition highlights the fact that legitimacy is a contestable validity claim; the stability of the order of domination (also) depends on its (at least) de facto recognition. (Habermas 1984: 178)

For Habermas, the process by which legitimacy is established or constituted - i.e. the process of 'legitimation' - is one where two sides struggle over the structures of 'political domination': "One side denies, the other asserts legitimacy." (1984: 179) Thus, political legitimacy is always intertwined with the political order and its relations of domination. The idea that "the neutrally observable efficiency of the state apparatus or of the economic system ... is effective for legitimation" is rejected here (1984: 181):

Whether legitimations are convincing, whether they are believed, depends naturally on empirical motives; but these motives are not formed independently of the (formally analyzable) justificatory force of the legitimations themselves. (1984: 183)

Habermas's definition essentially points to the necessarily intertwined relationship between political legitimacy and political domination. Thus, when we think of the legitimacy of the rulers' position as such, we can not simply discard the concept of domination. Moreover, when we think of this within the context of a cross-cultural 
struggle - where the victor is of a foreign culture to the defeated indigenous population ${ }^{18}$

- we must keep in sight that the legitimacy which the victors claim is, first and foremost, born from their victory in battle (Foucault 2003: 77).

In this context, legitimacy is not granted to the victors by consenting subjects i.e. the victors can not simply constitute their legitimacy within a social landscape that consents to their rule ${ }^{19}$. Legitimacy here must be forced upon the vanquished. The very presence of a foreign victor in the lands of the vanquished rests on their initial forceful and bloody insertion into such a position. It is this act of warfare that initially defines the victors as a dominant power: A power whose position as a legitimate interferer in the affairs of the vanquished was 'won' by force; a power whose position will remain as such by either the continuing exertion of its physical force or the mere threat of such action. Although this foreign victor will attempt to maintain its power through an indirect form (i.e. through a political project), it is this fact of forceful insertion that it can never escape: its legitimacy can never escape its forceful insertion, and its forceful insertion can never escape its ensuing political projects. This is a crucial point for our understanding of the relationship between war and the political project following $\mathrm{it}^{20}$.

War and political reconstruction are thus not two separate entities. They rather form a continuum in which relations of domination are not only established, but also

\footnotetext{
${ }^{18}$ This claim is compatible with the understanding that neither side is made up of a homogenous group. As German sociologist Emil Lederer (who was most interested in collectivity and war) observed in 1915, in times of war: "Society is transformed into a community, as the expression not of social solidarity, but of intensive mutual interdependence. All previously existing social groups whose existence had before been felt to be fundamental now pale into insignificance when confronted by the infinite unity of the nation that rises up gloriously to defend its native soil." (Quoted in Joas 2003: 79) Therefore, while internal differences are still pertinent for each side, such differences are (to varying degrees and for certain periods of time) pushed aside when the confrontation between two cultures is on-going. The internal differences within Iraq and their relation to this war will be discussed in Chapter Five.

${ }^{19}$ It is, of course, questionable whether this is possible within any context, and there exists much debate surrounding this point. That is a debate I will not enter into here.

${ }^{20}$ I cannot stress the following point enough: I am not making a universal claim here. This conclusion is only based on my study and analysis of this specific case.
} 
continuously resisted, modified, inverted, and negotiated. So, what does this all mean for the two-step plan? 


\section{Chapter Four}

\section{'The Two-Step Plan in Context'}

The two-step plan is akin to Foucault's schemata for the analysis of power. The first step of deconstruction is akin to the 'war-repression' schema. It deals with the forceful removal of Iraq's sovereign through an interplay of forces - i.e. through an actual battle. The neoconservative internationalists advocated the use of war as a preferable form of intercourse between the two sides: the US and Saddam's regime. This war would be the deciding factor in establishing the outcome of this opposition. After its 'conclusion', the victors (the US) gained the dominant position within this struggle by virtue of their military victory ${ }^{1}$. The American legitimacy as the power in Iraq was solely based on its forceful invasion of Iraq. Simply put, the discourse's architects sought to reaffirm America's position as the dominant force - as the 'strongest horse' - in its relations with the Middle East. Once the interplay of forces produced this outcome, once it was clear who stood where within this relation of domination, they advocated a second step to maintain and enhance this relation and America's dominant position within it.

This latter point is of immense importance for the neoconservatives. It can be seen in the displeasure expressed within the discourse with the 1991 Gulf War's conclusion i.e. Saddam remaining in power. This war is often referred to as 'the task left undone' (PNAC website: Kristol \& Kagan Jan. 1998), or the 'unfinished business of 1991' (PNAC website: Nov. 1998). Some even went as far as saying that for all the military

\footnotetext{
${ }^{1}$ Since Saddam's regime was the opposition, the discourse's proponents can state that victory was achieved.
} 
success of the 1991 war, it was largely a failure because Saddam remained in power (PNAC website: Gerecht May 2001). Furthermore, the discursive denunciation of the Clinton approach (discussed in previous chapters) towards Iraq, and the international order in general, illustrates the significance this discourse allocated to the initiation of a political project that would sustain the relations of domination born of war - whether it be the 1991 Gulf War or the Cold War.

The second step of political reconstruction is akin to the 'contract-oppression' schema. Once the US removed the sovereign of Iraq, the discourse's architects realized that it would be left with the task of governing the defeated subjects. But these architects never wished to take on this task. The desire was expressed in this discourse to move the task of governance to a new Iraqi sovereign as soon and as fast as possible ${ }^{2}$. In order to accomplish this, the war had to be pushed aside - even forgotten - and the task of realizing a just and new state would have to be quickly launched. Through the creation of a new state, it was believed that the battles of the initial invasion would be forgotten and placed in the dustbin of history. Once this new state was founded, the US could pull out of Iraq - its relations of force forgotten while the quest to realize a just and universal Iraqi state moves forward. The fighting, the blood, the destruction, and the violence - all of it lost and forgotten with the end of the first step and the initiation of the second. Most importantly, the new democratic Iraqi state would ensure that the benefits of the relations of domination born of the war were enhanced and sustained ${ }^{3}$.

As a result of their desire to enhance and sustain these relations of domination, along with the desire to operate in an 'in-and-out' fashion, the architects of this discourse

\footnotetext{
${ }^{2}$ The strategic options available for this task will be discussed in Chapter Five.

${ }^{3}$ Why a democratic Iraq is beneficial for American interests was discussed earlier in Chapters One and

Two. This point will also be briefly re-visited in Chapter Five.
} 
clearly make use of the strategic utility of the 'contract-oppression' schema. They believe that the second step of political reconstruction would enable the US to spare itself from heavy long-term involvement in Iraq and the Middle East, while still sustaining the relations of domination born of war. What is peculiar about this desire is that the transition between the first and second step is not considered to be theoretically problematic at all. This transition was clearly conceived as a theoretically smooth one ${ }^{4}$. Granted, there is an admission that, practically, this is not an easy task - i.e. it will require resources, commitment, and a strong political will. What I have argued through Clausewitz, however, is that theoretically it is not that simple either.

This is an extremely important point to consider at this conjuncture of the Iraq War. One can already see that most academic attention to this war has begun to focus on how the neoconservative plan 'got it wrong' because of its 'bad planning,5 or 'political misreads' on the reality of the world. As insightful as such efforts are, they do leave with us with the impression that had the US planned this mission better, the situation in Iraq would be much better today ${ }^{6}$. I believe that a critical examination of the theoretical thinking underpinning this approach is crucial for our understanding and analysis of this case and for future cases which can potentially follow its route.

The paradox facing the plan within this discourse is simple: the US must intervene in Iraqi lives in order to politically reconstruct their country; but since this intervention was only made possible through its initial violent insertion into Iraqi lives, it

\footnotetext{
${ }^{4}$ It is interesting to note that Bob Woodward noticed the same unproblematic view of this transition in his interview with President Bush nine months after the war began. When he asked the president about his meeting with Powell prior to the war, Bush answers "Basically what he was saying was ... that if in fact Saddam is toppled by military [invasion], we better have a strong understanding about what it's going to take to rebuild Iraq." Woodward added, “... as I listened I glimpsed what Powell had apparently seen uncertainty that the president fully grasped the potential consequences". (Woodward 2004: 152)

${ }^{5}$ An important exception to this was James Fallows' (2004) article, which will be discussed shortly.

${ }^{6}$ This point is also made by some neoconservatives and will be discussed in Chapter Five.
} 
cannot escape the forceful legitimacy that gives it the very right of intervention. This means that the effects internal to war are not easily cast aside into the dustbin of history. The relations of domination born of war, and the forceful legitimacy that necessarily accompanies such relations, will remain significant factors to consider in the aftermath of war. These can theoretically shape and re-formulate the specific elements of the political project that follows them. This political project, however, has as its ultimate end the sustenance of the relations of domination born of war - and there are many ways to achieve that end. In other words, the re-formulation of the specific elements of the political project does not necessarily translate into the failure of the political project to sustain the relations of domination born of war.

In short, my concern with the perception within the discourse of a smooth transition between the two steps lies in the question of resistance and the problematic subordination of war to politics in this plan. So, how does this help us make sense of the neoconservative 'in-and-out' plan towards Iraq, its strategic use of democracy, and, in turn, the two features of the discourse discussed at the conclusions of Chapter One and Two ('isolationism-expansionism' and its two-level thinking)? Before I address that question in the next chapter, I will examine how it was possible for the discourse's architects to overlook this paradox in the planning process -i.e. why was the reconstruction step viewed as the tool for isolation, thus ignoring all of the difficulties that arise from the use of war as a tool for politics? 


\section{‘Good vs. Evil' \& 'American Superiority' Re-visited}

Two of the five discourse components played an important role in shaping the planning process and the view of political reconstruction as the tool for isolation: the language of 'good vs. evil', and the feeling of unchecked American superiority. More specifically, two elements of these components are of importance here: the view of Americans as liberators rather than occupiers, and the belief in the superiority of American political institutions respectively. These elements not only played an important role in encouraging an expanded American role in the Middle East (see pp. 51-52), but acted to nullify the expansionist character of the plan as well.

Architects of this discourse were adamant that when American soldiers walk into Baghdad, they would be greeted by large Iraqi crowds eager to thank them for liberating them from Saddam's brutal regime. What is behind this view? It is the belief in the dualism of good and evil. For the discourse's architects, it is an unquestionable and unyielding fact that America is good, and Saddam is evil. More importantly, this is not only true for Americans, but for Iraqis as well. Iraqis have yearned for this liberation for some time now, and only Saddam's firm grip on power had prevented it. Therefore, any force that overthrows Saddam will be greeted with joy and open arms. This means that America's reconstruction project will be accompanied by substantial involvement of Iraqis. Once the US places the Iraqis on a path of American-style democracy, it will slowly remove itself from Iraq and isolate itself from the region.

America's role in building this path would involve reaching two general objectives: (1) holding free and open elections, i.e. every Iraqi would have the right to elect freely and without being coerced to vote for any one leader, and (2) creating an Iraqi 
constitution that adheres to Western values, namely the inclusion of all ethnic and religious Iraqi groups within the electoral process and the tasks of governance. These two objectives primarily define the neoconservative conception of democracy in Iraq. The discourse's architects are not concerned with questions that most academics debate: what does it mean to be a democratic subject? Does civil society proceed or precede democracy? What role should an independent media play? How do you hold public servants accountable for their actions? How do you even make the transition from 'rulers' to 'public servants' in political public discourse?

Moreover, more concrete questions surrounding the insertion of a democratic system into the Iraqi cultural context are ignored. In Blind into Baghdad James Fallows documents how the Bush administration ignored the State Department's Future of Iraq Project which, well before the war, outlined and warned about many of the difficulties an invasion of Iraq would bring (Fallows 2004: 54). Some of these questions include: how quickly can power and water supplies be restored? Holding fair and open elections without such resources is difficult to accomplish (2004: 57). What is the US to do with Iraq's remaining army? Disbanding the army would create massive unemployment and unrest among militarily trained men (2004: 57-58). How will the US quickly fill the power vacuum left by Saddam's removal? Scores and rivalries between different Iraqi tribes and groups are sure to be settled in a violent, chaotic manner as soon as Saddam is removed (2004: 68). Furthermore, this post-invasion civil disorder could destroy important infrastructure even if precision bombing kept them intact $(2004: 69,73)$.

All of these different questions concerning Iraqi democratization essentially point to the paradox I am interested in highlighting: how will Iraqis, from different 
backgrounds and ethnicities, make a quick transition from living under a tyrant to living through 'self-rule'? And more importantly, will Iraqis even see themselves in the midst of such a transition when they witness the presence of foreign soldiers on the land they are strongly attached to - when they see foreign soldiers intruding on the sanctity of their land? Even if Americans are welcomed as liberators, how long will it be before their prolonged presence makes them look like invaders in the eyes of Iraqis? (Fallows 2004: $68)^{7}$ In short: how is this transition from the first to the second step possible? When the discourse's architects were presented with these questions, they largely chose to ignore them; why? Fallows argues that ignoring the Future of Iraq Project was not an innocent case of negligence, but rather an intentional act on the part of the 'war hawks' within the Bush administration (2004: 70-74). While the individualistic 'psychologies of power' explanation Fallows provides (2004: 74) is interesting, I wish to make a more sociological, discourse-based, explanation as to why the discourse's architects (and thus the administration) ignored these kinds of warnings, even though they were well aware of them.

The discourse's architects ignore these questions because they believe that they do not really matter. They argue that any form of democracy, no matter how primitive or 'flawed' (PNAC website: Kagan \& Kristol May 2004), will be an improvement over Saddam's regime. They admit that an advanced democracy cannot develop overnight; but Americans need only build the necessary foundations of democracy. The maturation of the system in Iraq will eventually depend on Iraqis in the future, but whatever the outcome, it will be a superior system to Saddam's regime; how so? The discourse's

\footnotetext{
${ }^{7}$ This concern was raised by the War College team in mid-December of 2002 in a report titled Reconstructing Iraq: Insights, Challenges, and Missions for Military Forces in a Post-Conflict Scenario. (Fallows 2004: 68)
} 
architects argue that America will have built this system's cornerstones in accordance with those of American democracy, and the belief in American exceptionalism means that these foundations will give birth to the most advanced system human kind has ever seen. Iraqis will realize this fact quickly because this system, even in its primitive or rudimentary form, is inherently superior to the one Iraqis have suffered under for so long. All human kind will agree with this reality if presented with the opportunity to experience it $^{8}$. It will not be long before Iraqis realize that the step of political reconstruction is in fact America's gift to Iraq and the Middle East; not an American attempt to occupy Iraq. Iraqis will surely come to see what Americans already know about the superiority of America's 'way of life'. Once they do, Iraq will become America's ally, not its enemy. In short, the discourse's architects argue for an expanded American role only in the initial stages of the political project. Once Iraqis begin to move forward with the task of making democracy work for Iraqis, America will let them proceed on their own and withdraw itself from Iraq.

To sum up, most of the harder questions about political reconstruction were largely ignored. The neoconservative conception of democracy in Iraq mainly entails an institutional view: build institutions and implement basic democratic laws, and there is your democracy in Iraq. Architects of the discourse basically aim to establish a skeleton

\footnotetext{
${ }^{8}$ In the following piece, Reuel Marc Gerecht captures this point. In reference to the repercussions of Iraq's elections on Egypt's political system, he writes: "The democratic ethic is trying now to put down deep roots in Iraq; the democratic spirit, however, has been present in the Middle East for a lot longer. The understanding of it has grown as tyrannies have failed (but continue to rule on), elite corruption has skyrocketed, and the number of those who have known the penalties for political deviation has risen to produce a counterculture of resistance, pride, and small-scale heroism ... Hosni Mubarak probably doesn't really care about this. That he rules is enough. But the apparatus below him does ... Go into the streets of Cairo and ask the poor urbanized fellah whether he understands one man, one vote, and you will discover that he has an understanding that vastly exceeds his experience of democratic politics (zero). He has learned by seeing the opposite." (PNAC website: Gerecht Feb. 2005)
} 
of democracy; the rest is up to the Iraqis to build once the Americans leave. Once Iraqis begin this process and begin to experience the fruits of democracy, and undoubtedly they will, they will not fight American interests; they will not even fight American intervention, but welcome it.

In this view of political reconstruction lie the roots of the belief in a theoretically straightforward transition from the first to the second step of the neoconservative plan. In the belief that America is primarily offering Iraqis a gift lays the justification of the use of war as a means towards a political end. It works as follows: since Americans are improving Iraqi lives by building them a democracy (not to mention acting to fulfill its duty as world leader and protector of civilization), then the war is justified - it is for a greater good; and this greater good will overshadow the violence of war.

The architects of the discourse basically believed that the simple exposure of the Iraqi people to democracy will make them forget about the war which had just made its entry into their lives. Behind this argument is the blind belief in American moral and political superiority - in American exceptionalism. This belief nullifies the expansionist character of this tactic: it turns the imposition of democracy into a gift-giving act. More importantly, it turns war into a mere step along a path of a 'greater good' - it gives credence to the subordination of war to politics. Because of this conviction in American exceptionalism, the discourse's architects fail to see the paradox facing the two-step plan.

In the first few pages of this thesis, I asked the question of why it was that this self-proclaimed guardian of civilization reverted to a gruesome instrument such as war. I now realize that it is precisely because the US proclaims this position, that it sees it fitting to revert to war. Next, I examine the two features of the discourse. 


\section{Chapter Five}

\section{'War, What is it Good for?'}

I will take a moment to recap here: A straightforward transition between the first and second step in the neoconservative plan is integral to its success in ensuring American withdrawal from Iraq and the Middle East. The principal force behind the discourse's unproblematic take on the transition involves the view of war as a means towards a political end. This view of war is fueled by the belief in American exceptionalism, and the desire to find a fast solution to the Saddam question. I have argued that the subordination of war in this plan is quite problematic, making this transition anything but straightforward. The second step of political reconstruction is likely to maintain an important element from the first step of forceful American insertion: forceful legitimacy. This connection between the two steps is likely to present difficulties for the neoconservative plan to utilize political reconstruction as the tool for isolation. Next, I examine what all this means for the two stated objectives of the neoconservative discourse - democracy and security - through an examination of the discourse's two defining features: two-level thinking and isolationism-expansionism.

\section{A War for Democracy? The Discourse's Two-Level Thinking}

The discourse's architects set forth two objectives for Iraqi democratization: elections and a constitution. These objectives aim to place the Iraqis on a path specific to the desires and wishes of American strategic interests. Political reconstruction essentially 
aims to ensure that American influence in Iraq will be forever felt - albeit an indirect influence. This approach is very similar to the British strategy towards India during its period of colonization. That strategy was best captured by Charles Trevelyan in the late $1830 \mathrm{~s}$, when in reference to the inevitable prospect of Indian independence, he writes, The only means at our disposal for preventing [revolution] and securing [reform], is to set the natives on a process of European improvement, to which they are already sufficiently inclined. They will then cease to desire and aim at independence on the old Indian footing. (Quoted in Scott 1995: 215; original emphasis)

The neoconservative plan operates with a similar idea in mind: let the Iraqis choose the shapes and forms of this new path they are on, but the Americans must and will decide which direction this path will point towards. Essentially, this is meant to propel Iraqis into a political system that will transform them into subjects who cannot and will not oppose the relations of domination born of war 'on the old Iraqi footing'. The purpose of this strategy is to let the opposition in Iraq reside between the different Iraqi groups over 'the legitimate and the illegitimate' apparatuses of democratic governance. Through this process of democratization, therefore, the opposition between Iraqi and American forces would slowly fade away - i.e. the opposition would shift from a context of 'warrepression' to one of 'contract-oppression'.

The second step of democratization is therefore a strategic tool and not an end in itself. Its strategic use is to sustain the relations of domination born of the war, while simultaneously isolating America from Iraq and the Middle East. Now, I wish to make one point clear: the discourse's architects clearly view this democratization process as the most desirable and suitable option for achieving this strategic goal - why? Because hiding the relations of domination born of war between Iraqis and Americans is best 
accomplished by moving Iraqi energies of resistance inwards and towards an opposition between the legitimate and the illegitimate forms of governance. If the legitimate forms of governance in this opposition have just some of the hallmarks of American democracy, then America has not only hidden the opposition between Americans and Iraqis, but will have also created important allies (because of the regions' oil; see pp. 32-34, 56-58) for the future ${ }^{1}$. Ultimately, this will go a long way in creating an international atmosphere conducive to an American victory in future confrontations with hostile superpowers.

Having said that, architects of the discourse leave the door open for other American exit strategies from Iraq should it become too difficult or costly to stay the course of democratization. I am not speculating here about what will actually transpire in Iraq in the next few years; that will be the task of future historians to document. I am simply making the point that a failure of democratization does not necessarily translate into the failure of the political project to reach its aim of sustaining the relations of domination born of war. Should democratization fail, other options are available. The main option is simple: divide and rule. If the different Iraqi factions simply refuse to join together in a unified democratic government, then so be it - let the country break up. In response to the Clinton administration's refusal to invade Iraq because of its concerns over the potential eruption of civil war, Richard Perle writes:

The obsession with "stability" has inevitably led the administration to regard Saddam's repression as a tolerable price to pay for maintaining it. But the idea that a stable Iraq requires a strong, repressive leader like Saddam (or some Ba'athist successor, ideally chosen by the United States), or that an Iraq led by such a leader is certain to be more stable than a freer, but perhaps less unified Iraq, is highly questionable. A new leadership preoccupied with domestic affairs ${ }^{2}$, and ready to abandon the drive for weapons of mass

\footnotetext{
${ }^{1}$ Remember the discourse's firm belief in the idea that democracies simply do not fight wars with each other, and are indeed more likely to fight along side each other in any major ideological clash.

${ }^{2}$ This illustrates the desire to see Iraqis turn their energies inwards.
} 
destruction, would surely be preferable to Saddam - or yet another military dictatorship - even if the process required to bring about such a change carries some risk of Iraq breaking up. (Perle 2000: 102; emphasis added)

Put simply, not only does Iraq not have to attain an advanced democracy to be considered a success; it does not even have to be one country called 'Iraq' for it to be deemed a success for the neoconservatives. The reasoning behind the latter option is simple: if a fragmented Iraq does not begin a process of dramatic political and social transformations in the region, it nonetheless would have prevented Saddam from gaining regional domination and, in turn, would have sent a powerful deterrent message to other regional leaders with such plans ${ }^{3}$. Moreover, the opposition between these different Iraqi groups would surely move slowly out of the picture America's involvement in Iraq and the region - Iraqis would become 'preoccupied with their domestic affairs'. This, however, is by no means an agreed upon issue within the discourse. Some believe that building a democratic, stable, and unified Iraq is not only the favored option, but the only strategy that can achieve America's mission and serve its strategic interests. That faction of the discourse, however, seems to currently be on the losing end of this debate:

Calls for a withdrawal from Iraq are starting to pop up all over the place now and will proliferate in the coming days and weeks. I find even the administration's strongest supporters, including fervent advocates of the war a year ago and even some who could be labeled "neoconservatives," now despairing and looking for an exit. They don't put it quite that way, of course. Instead, they say that seeking democracy in Iraq is too ambitious; we need to lower our sights and settle for stability ... Faced with [the] reality [of war], conservatives and even neoconservatives can be heard muttering these days that if the Iraqis won't take responsibility for their own country, we should leave them to their fate. That is what "lowering our sights" really means ... So get ready for the coming national debate over withdrawal. The unthinkable is becoming thinkable. And it isn't hard to understand why ... It is the sense that Bush officials don't know what they are doing that has fed all the new talk about "lowering our sights." No one will say, "Let's cut and

\footnotetext{
${ }^{3}$ This is precisely what 'Rapid Dominance' and 'Shock and Awe' were meant to achieve.
} 
run." Instead, people talk about installing a moderate but not democratic government. They talk about letting Iraq break up into three parts: Kurd, Shiite and Sunni. But at the core, this is happy talk, designed to help us avert our eyes from withdrawal's real consequences. The choice in Iraq is not between democracy and stability. It is between democratic stability, on the one hand, and civil conflict, chaos or brutal, totalitarian dictatorship and terrorism, on the other ... The truth is, if the goal is stability, that the alternatives are no easier to carry out and no less costly in money and lives than the present attempt to create some form of democracy in Iraq. The real alternative to the present course is not stability at all but to abandon Iraq to whatever horrible fate awaits it: chaos, civil war, brutal tyranny, terrorism or more likely a combination of all of these - with all that entails for Iraqis, the Middle East and American interests. (PNAC website: Kagan May 2004) ${ }^{4}$

In sum: whether the new Iraq is a rudimentary democracy that only carries the skeleton of democracy, or whether it is a fragmented country with a number of warring tribes and groups, the discourse's architects believe that the purpose of sustaining the relations of domination born of war would be served. Based on this examination of the discourse's conceptualization of democracy and the process of political reconstruction, I argue that the idea that this war was in fact a war for democracy is, at best, supplementary to the neoconservative plan. The overriding level of strategic thinking means that the process of democratization was always going to be undertaken for a higher objective and never as an end in itself. Iraqis were only important in so far as their energies of resistance were directed somewhere other than America's strategic interests. The idea that this was a noble war for a noble cause was always an afterthought. Should this 'noble cause' prove to be too difficult to accomplish (although the neoconservatives attempt to make its accomplishment as easy as possible), it could and would be dropped.

\footnotetext{
${ }^{4}$ Having said that, it should be noted that Kagan \& Kristol argued just nine days later that the democracy being advocated above is still a rudimentary one (PNAC website: Kagan \& Kristol May 2004).
} 
To conclude, while the discourse's architects attempt to give birth to (or as most of them believe: revive) an approach to foreign affairs that equally considers America's moral values and America's strategic interests in its thinking, an asymmetrical relationship between these two levels is born in the discourse and, more importantly, in its planning processes. I am not arguing here that the infusion of moral thinking into the discourse is mere rhetoric that is aimed to divert attention from the discourse's 'real' intentions. My point is that while these architects claim that they combine the two types of thinking into a 'distinctly American internationalism', a close examination of their planning processes suggests that they fail in this attempt. This failure has produced an asymmetrical relationship between the two levels; thus making the claim that this was a war for democracy a problematic and an uneasy one for the discourse's proponents - a sense of uneasiness that can be seen in Robert Kagan's quote above.

\section{A War for Security? The 'Isolationism-Expansionism' Tension}

This point I will concede: war can be an effective tool for establishing relations of domination against a specific target. The Iraq War did successfully and quickly remove Saddam Hussein from power - his regime was clearly the loser of the war. This approach, however, is particularly problematic in this case because the discourse's architects do not desire long-term and direct American involvement in Iraq and the Middle East. They want to operate in an 'in-and-out' fashion. The 'in' of expansionism, however, uses a very intrusive, a very visible and direct method: war. Due to the aforementioned difficulty in casting aside this tool, the 'out' of isolationism is not as easily achieved as planned; how so? 
The 'in-and-out' approach towards Iraq is basically a more concrete manifestation of the isolationism-expansionism tension that defines this discourse. At the conclusion of Chapter Two, I argued that this tension makes clear the discourse's use of war as a tool for politics. I argued that since the architects of the discourse required a fast solution to America's predicament with the Middle East, they advocated for forceful American expansion in the region; and since their visions were geared towards an isolationist America, they advocated a relatively quick withdrawal from the region thereafter. This desire indicates the pertinence of a Clausewitzian view of war in the discourse. This Clausewitzian view holds together the presumed smooth transition between the first and second step of the plan - the very presumption that makes the 'in-and-out' approach theoretically viable. Consequently, the plan's theoretical problems begin, like Clausewitz's, with the question of resistance.

This war did not turn out to be the small 'scuffle' that few will remember. The ferocity and duration of the resistance was certainly underestimated by the discourse's architects. In this case, it seems that the weak are making use of the strategy Clausewitz had outlined: prolong the fight - tire out the will of the strong. Many in the discourse see this strategy in the Iraqi insurgency following the toppling of Saddam:

But the insurgents do not have to win; they simply have to avoid losing. Their goal is not to change the facts on the ground as much as to change American perceptions of the viability of the president's vision for Iraq. (PNAC website: Donnelly \& Schmitt Oct. 2003)

Furthermore, they admit that the Iraqi insurgency is a growing problem for America's mission in Iraq and that it threatens its success ${ }^{5}$ :

\footnotetext{
${ }^{5}$ Even Dick Cheney, the fervent supporter of the 'liberators' not 'occupiers' viewpoint, admitted this much in his interview with Don Imus: "I think the hundreds of thousands of people who were slaughtered at the
} 
Yet the debate has focused on whether we have enough troops, rather than whether we have the right forces, in the right places, using the right stratagems to defeat the amalgam of hard-core Baathists, Iraqi opportunists and radical Islamists from outside the country who continue to wage unconventional war against the U.S.-led occupation. Although the Bush administration can rightly point to successes in reconstructing Iraq since Saddam Hussein's regime was toppled, the fact remains that unless the security situation in Iraq is brought under control and the insurgency there decisively defeated, those successes can never be made permanent and the president's larger hopes for a stable, democratic Iraq will never be fulfilled. (PNAC website: Donnelly \& Schmitt Oct. 2003)

Despite indicating a need to move away from the 'troop numbers' debates in the statement above, many in the discourse (including Schmitt - see PNAC website: Schmitt Sept. 2003) argue that the low number of troops in Iraq is one of the decisive factors in the insurgency's continuing potency. Despite the fact that Robert Kagan and William Kristol admit in the following piece that war was always going to be a volatile and unpredictable tool, they remain adamant about the idea that a miscalculation on the required number of troops is the culprit, not the subordination of war in the two-step plan:

The mere fact that violence has increased recently in Iraq is not by itself grounds for criticizing the administration's handling of the war. No sensible person believed that the effort to build a democratic Iraq would be without cost and dangers. No reasonable person expected administration officials and military commanders, either in Washington or in Baghdad, to be able to exercise unerring mastery over an inherently complex and always explosive situation ... Serious errors have been made - and made, above all, by Donald Rumsfeld's Pentagon. The recent violence in Iraq has confirmed that the level of American military forces has been too low to accomplish the president's mission ever since the invasion phase of the war ended last April ... The stresses we're under now cannot be chalked up to the "fog of war" or simple bad luck ... at the end of the day, it is up to the president to ensure that the success he demands in Iraq will in fact be accomplished. If his current secretary of defense cannot make the adjustments that are necessary,

time, including anybody who had the gumption to stand up and challenge him, made the situation tougher than I would have thought ... I would chalk that one up as a miscalculation, where I thought things would have recovered more quickly." (Quoted in Washington Post report by Jim VandeHei, January 21, 2005; p. A02; emphasis added) 
the president should find one who will. (PNAC website: Kagan \& Kristol April 2004)

As this statement shows, much of the blame has been placed on one of the discourse's staunchest supporters within the Bush administration: Donald Rumsfeld and his alleged miscalculation of the number of troops needed to reconstruct $\operatorname{Iraq}^{6}$ (Schmitt also blames Rumsfeld here - PNAC website: Schmitt Sept. 2003). Despite all of the now admitted difficulties facing the neoconservative plan, its architects are still not questioning its fundamental aspect - the use of war as a subordinate tool to politics. They are rather looking for faults in individuals who had played an important role in executing the plan. While I do not wish to underestimate such mistakes, I remain focused on the idea that it was the very make-up of the plan that was the culprit, not the miscalculations of those who executed it.

As Donnelly and Schmitt (PNAC website: Oct. 2003) point out, the resistance in Iraq is clearly aiming to prolong this fight; it is relying on the strategic idea that the longer the fight carries on and the more intense and ferocious the fighting is, the more likely the resistance will have its political ends met $^{7}$. It is always important to remember what Clausewitz repeatedly warned about: there are an infinite number of ways to victory in war (Clausewitz 1943: 289). What may seem like the end of the war for the strong may only be the beginning of a long and hard-fought war for the weak. Architects of the discourse are slowly seeing this peculiarity of war and resistance in Iraq. They are slowly

\footnotetext{
${ }^{6}$ The pressure placed on Rumsfeld for his alleged mishandling of Iraq, particularly surrounding the Abu Ghraib scandal, was quite great - William Kristol even publicly asked for his resignation in the Washington Post on December 15, 2004 (p. A33). This pressure led Rumsfeld to admit that he had twice offered his resignation to President Bush; this admission came on an interview with Larry King on February 3, 2005. ${ }^{7}$ I will not speculate about what the specifics of these political ends are. Multiple groups make up this resistance, and each probably has different political ends it wants to achieve. Suffice it to say, these groups do seem to have one unifying goal: fight American occupation of Iraq, and American intervention in Iraqi and Arab lives.
} 
succumbing to the idea that it is very difficult to eradicate a force of resistance for which the strong side has no clear view, calculation, or estimation. Due to its inability to claim the eradication of something it could not predict in scope and capacity beforehand, the stronger side in a war becomes slowly entangled in a prolonged battle that it was not prepared for, or did not care to fight. This means that this protracted conflict is slowly becoming the defining feature of this intercourse between the two cultures.

Faced with this difficulty, architects of the discourse are now trying to push the political project further and faster in order to eradicate the resistance and put an end to a fight that has gone on for much longer than anyone in the discourse had predicted. While making the case for holding early Iraqi elections (September 2004) as an alternative to 'lowering our sights', Kagan \& Kristol write,

As for those who rightly point out that the schedule we suggest would make for a hasty and imperfect election process and that much could go wrong, we agree. But even flawed elections in Iraq would contribute to a sense of political progress - of movement toward legitimate self-government - that would give us a chance of improving the situation." (PNAC website: Kagan \& Kristol May 2004; emphasis added)

This means that America must use politics to defeat the insurgency that was created by war. Fine, but does this not mean that the discourse is moving from a conception of war as a continuation of politics, to a conception of politics as a continuation of war? If forcing the political reconstruction upon Iraq (regardless of the consequences) is the neoconservatives' method of eradicating the resistance, then does this not make clearer the point that their approach to political reconstruction is more of an attempt to keep in place the relations of domination born of war, rather than an attempt to offer democratization as a gift to Iraq? Does this not make political reconstruction look like the 
continuation of war - the implementation of an imperialist or a neo-imperialist system, and thus making this conflict longer and more complex? In a word, does this not sink America deeper into a fight in Iraq and the Middle East, where the political intercourse between the two sides becomes more deeply interconnected with the relations of force that characterized the war preceding it? Does this not sink the discourse deeper into the paradox of war and politics? This paradox is now facing the discourse with all of these difficult questions that come along with it, and the discourse's architects have yet to address these questions. The paradox that Clausewitz could not overcome is now presenting itself to the discourse, and I have not seen any signs indicating that its architects are capable of dealing with it. More troubling for the neoconservatives, their focus on Rumsfeld's failures suggests that they have not even seen this paradox yet. What may this failure mean for the neoconservative discourse?

We are now clearly witnessing the admission within the discourse that this is officially a protracted conflict, with no end in sight. Moreover, we are witnessing the admission that the 'all-overpowering' element of war is slowly re-defining the initial political project this war was meant to achieve: democratization is slowly being dropped for other exit strategies that could sustain the relations of domination born of war (PNAC website: Kagan May 2004). In my view, this protraction is likely to have three important points of impact - all relating to America's forceful legitimacy, and with implications to America's security. A discussion of these will also highlight the paradox facing the discourse, and its architects' inability to deal with it.

The first point involves internal Iraqi politics. As previously mentioned, the neoconservatives are clear about their desire to implement American-style democracy, 
and their intent to support Iraqi political groups that adhere to this democratic system - to the 'legitimate' apparatuses of governance. Since America's backing of democratization rests on a claim of legitimacy that was backed by force, then so the new Iraqi groups' claim to legitimacy will likely rest upon. This means that such Iraqi groups will not easily be able to escape the forceful legitimacy (transmitted over to them from the Americans) that provides them with the very basis of legitimation. Forces of Iraqi resistance against the American invasion are sure to have an 'American' $\operatorname{target}^{8}$ to attack even after the physical exit of American forces from the streets of Iraq ${ }^{9}$. The relations of domination born of the war are thus sure to be felt long after America's 'exit' from Iraq, thus hindering America's withdrawal from Iraq and the region.

But, for the sake of argumentation, let us assume that the first point of impact takes the "optimistic" route some in the discourse assume it would: if internal fractions in Iraqi politics prevent the creation of a stable and unified Iraq, then the intensity of their fighting will make the struggle solely their own - i.e. they will forget about America's role in this struggle in due time ${ }^{10}$. To this I say: fine, the Iraqi internal politics is left to be fought between Iraqis and Iraqis alone - should the Iraqis use the 'rhetoric' of the war as grounds to dismiss the legitimacy of any US backed groups, then so be it, it is only rhetoric and no substantive number of American lives would be threatened. Iraqis, Arabs,

\footnotetext{
${ }^{8}$ One can already see this development by reviewing the recent surge in attacks against Iraqi civilians and potential Iraqi police and army recruits. In an interview on CNN, Iraqi interior minister Baqir Jabbur estimated that attacks between January and June of 2005 alone had killed 8,175 Iraqi civilians and injured 12,000 more (reported in cnn.com on June 30,2005).

${ }^{9}$ As mentioned earlier, a military presence (likely in the form of near-autonomous bases) will remain in Iraq.

${ }^{10}$ It is not clear to me who currently represents these voices. Certainly, Richard Perle feels that Iraq's fragmentation would not deal a fatal blow to America's strategic interests, and I would consider him as part of this group. The other voices that Robert Kagan refers to in the quote on pp. 114-15, however, are not mentioned in name anywhere in that article. Nonetheless, since Kagan is an important 'insider' to the discourse, I assume that this claim is a well-grounded one.
} 
Americans, and the world will give as little attention to Iraq's failed democracy as they did to the official end of America's search for WMDs in Iraq on January 12, 2005. Moreover, the strategic interest of preventing a hostile rogue from gaining domination over the region and its oil is served. That sounds strategically logical, but it ignores the second and third points of impact I wish to highlight next.

The second point of impact is American-Arab relations. We cannot forget one of Clausewitz's first comments on war: "War is a form of human intercourse". (Clausewitz 1943: 357) This war has written an important chapter in the cross-cultural interaction between Americans and the Arab world. It has become, and will likely continue to be, a point of historical reference guiding the kind of intercourse the two cultures engage in. Far from isolation, war places the two cultures in a forced co-existence characterized by animosity and the language of force. This point is not likely to be lost on future Iraqi and Arab generations that will grow up with this language of force, and the reality of war and violence $^{11}$. When thinking about matters of warfare and all of the killing and destruction that comes along with it, it is wise to remember that the victors may forget about the killing of innocent civilians - they may dismiss such action as "collateral damage, ${ }^{12}$, but in the words of Noam Chomsky, "the victims do not so easily forget." (Chomsky 2003: 153) In the long run, if democratization fails, if Iraq is allowed to spiral into civil war, then Robert Kagan's fears (see quote on pp. 114-15) may prove to be prophetic for the

\footnotetext{
${ }^{11}$ Because the theatre of war is in Iraq and the Middle East, I only mention the Arab generations here. Having said that, sociological inquiries into the effects of war on the fighting men and women from the attacking countries has shown that the violence which these young men and women live through has dire consequences on the societies that send them to war - shortly before and during the war, but particularly after they return from duty (e.g. their increased propensity to commit family violence). Hans Joas (2003) discusses this strand of sociological literature and some of its findings, focusing particularly on the literature dealing with the effects of the Vietnam War (see Joas 2003: 111-121).

${ }^{12}$ While the Pentagon's official statement is that it does not keep a tally of civilian casualties, independent estimates range between the 16,000 to the 100,000 Iraqi civilians killed since the US invasion in March of 2003 (Reported in the Washington Post, Rob Stein, October 29, 2004; p. A16).
} 
region and for America's war on terror. What Robert Kagan basically fears (and conversely what Perle and others seem to be untroubled by) is this: the rise and spread of animosity among the Arab populace. For Kagan, winning the 'hearts and minds' of this populace is crucial to America's success in its war on terror. Should democratization fail, the "Arab street" that the neoconservatives want to win over to the side of freedom and democracy will likely begin to see this American mission as an imperialist one (or more properly become still more rooted in this view) ${ }^{13}$. What Kagan is telling Perle and others is simple ${ }^{14}$ : while the short-term security of the US may be served if Iraq's democratization fails, the long-term effects are sure to be counter-productive for American security ${ }^{15}$. Democratization's failure will likely mean that Arabs will come to see this mission as an attempt to subjugate the "Arab street", not resurrect it. The asymmetry in the discourse's two level-thinking may prove more costly than seems at first sight.

The relations of domination this war has created, and the forceful legitimacy that holds them together, raise serious problems for the discourse's isolationist elements particularly the desire to maintain and enhance American sovereignty and security by hiding the relations of domination born of war. The neoconservatives' dependence on forceful legitimacy to implement change in Iraq and the Middle East will not likely hide these relations, but rather lead to prolonged conflicts and fierce Arab resistance to American intervention in Iraq and beyond. Far from peaceful co-existence, this will likely result in a cross-cultural relation that is characterized by warfare, and one spoken through

\footnotetext{
${ }^{13}$ Such sentiments are already rampant in the region.

14 This is not an open debate between Kagan and Perle. I have chosen these two because of their clarity on where they stand.

${ }^{15}$ America's increasing inability to effectively deal with threats from the Middle East such as Iran and international terrorism are already being seen.
} 
the language of force. The forceful 'in' of expansionism is proving to be too powerful for the quick 'out' of isolationism to take place. This is slowly leading America into a protracted conflict not only in Iraq, but in the Arab world in general.

The third point of impact is the grand vision expressed in the discourse. This vision can perhaps be seen more clearly now: the forceful 'in' of an expansionist America - the America that will forcefully build the world order that could be run by networks of power, is only carried out for the sake of the 'out' of isolationism - the dream of a prosperous America far from the world's problems and dangers. But that is not all. The speed with which the discourse's architects want to operate in Iraq is present in this grander vision as well, and the fastest method of implementing change is to force it upon systems and peoples through military and forceful means. The Iraq War was not only meant to implement fast change in Iraq, it was a signal to the international community as well. By going to war outside the legal and political structures of the Security Council ${ }^{16}$, the neoconservatives wanted to make their position clear to the international community and the institution that symbolically represents it: the UN. Their message to the UN was simple: reform in accordance with American wishes, or face irrelevance. America's hegemony was to be made clear for all to see, so that America can begin its isolationist retreat to a life of prosperity, security, and freedom. In short, the discourse's architects believe that America must use 'hard power' in order for it to attain, maintain, and enhance the 'soft power' they so desperately desire.

The expansionist course these architects adopted, however, shares the very same difficulties faced by their course in Iraq. Their advocacy for fast change means that they

\footnotetext{
${ }^{16}$ I do not mean to enter into a debate here surrounding the legality of the war vis-à-vis international law. I rather only refer to the fact that this war was not sanctioned by the Security Council.
} 
are less hesitant, and indeed quite likely, to use military force to achieve the desired political ends ${ }^{17}$. This course, however, is not a mere step along the way to America's freedom from the world - it is a step leading to its own path: one of war and violence. Far from allowing Americans the freedom to choose their own path, these architects are advocating an approach that further deepens America's relations with the outside world. And because of their intent to use force, they are not creating relations of peace and coexistence; rather they are relations of coercion and force.

The language of force that was used in this mission has made its mark on human cross-cultural interaction once more. Succinctly put, the neoconservative plan re-affirms to the world that war remains a legitimate and justifiable form of human intercourse. This message will not be lost on America's enemies and potential future adversaries. What may that mean? The preoccupation within the discourse with a future military clash with China, along with the expressed intent on using military force to implement 'regime change' in rogue states (e.g. Iran, Syria, and North Korea) that could impede America's success in such a clash, could produce a self-fulfilling prophecy. American expansionism may arouse these nations' feelings of vulnerability, and thus push them further to pursue significant military upgrading, and give them a more urgent need to 'go nuclear' ${ }^{18}$. While backed by recent news reports and independent academic investigations, the latter point does remain highly speculative; but it is meant to primarily highlight the multiple levels at which security operates. In other words, security does not always follow a straight formula of: removing potential threats equals enhanced security. Security is much more

\footnotetext{
${ }^{17}$ While perhaps the Iraq War sent this message to the international community, it is not currently clear whether or not the discourse's architects can pursue their earlier desires to keep utilizing military means in theatres such as Iran, Syria, or North Korea. Rapid Dominance has not proven to be as efficient as its architects had hoped.

${ }^{18}$ Or in China's case, to simply further upgrade its nuclear arsenal.
} 
complex than that, particularly when the 'removing tool' is as insecure and unpredictable as war. If the speculations above seem too far-fetched, one need only examine the insecurity created from the war with regard to terrorism. A recent report by the Central Intelligence Agency (CIA) concluded that terrorists have now in Iraq a more advanced, informed, and effective training ground than the al-Qaeda camps in Afghanistan ever were ${ }^{19}$. This means that the 'terrorist' side of the insurgency is using the chance created by America's invasion to promote its own strategic interests and ideological beliefs. In other words, the discourse's architects may be right to believe that war can create an atmosphere conducive to change, but they forgot that America's enemies could just as well use the atmosphere of war to advance their own strategic interests, and shape the world in accordance with their own ideological beliefs.

Whether or not this war has served American security is inconclusive and dubious at best. There are multiple levels at which security operates, and there is no simple or straightforward formula that can determine whether or not America is safer today than it was before its invasion of Iraq. What may seem to Perle as an acceptable price to pay for Iraq's fragmentation seems far too costly for Kagan. What Wolfowitz regards as a necessary step for a future clash with China may prove to be a self-fulfilling prophecy rather than a prudent strategic step in the long-run. What the neoconservatives view as one step of war that will aid in shaping the world in America's image may be the chance

\footnotetext{
${ }^{19}$ This is a classified report whose findings were aired on CNN on June 22, 2005. On the CNN report, CIA director Peter Goss was shown testifying: "Islamic extremists are exploiting the Iraqi conflict to recruit new anti-U.S. jihadists. Those jihadists who survive will leave Iraq experienced and focused on acts of urban terrorism. They represent a potential pool of contacts to build transnational terror cells, groups and networks in Saudi Arabia, Jordan and other countries." (Transcript can be found on: http://transcripts.cnn.com/TRANSCRIPTS/0506/22/ldt.01.html)
} 
America's enemies have been waiting for, and currently taking advantage of, in order to advance their own strategic interests and to shape the world in their own image.

\section{What Next for the Neoconservative Discourse?}

As mentioned in Chapter Four, architects of the discourse of a 'distinctly American internationalism' failed (and continue to fail) to see the paradox in their plan because of their conviction about America's righteousness. No international law or outside restraint was ever going to stand in the face of this conviction. They believed that they were morally right in this mission, and anyone who questioned the two-step plan was therefore questioning the moral superiority and righteousness of America. For the neoconservatives, this was a war of 'good intentions', and therefore just.

For all the controversy surrounding him, I believe that Carl Schmitt was right on at least one point. Schmitt argued that wars are best held in check when they are fought only for specific interests, and without any illusions of moral superiority (Joas 2003: 2122). Any moral devaluation of the enemy is a threat to peace. Such devaluation results in the eradication of all inhibitions in war and war-making by turning political struggles into a fight between the preservers and the destroyers of order and peace (Joas 2003: 22). Meaning, forget about 'good intentions' in war - wars can only serve specific selfinterests. I am not saying that Schmitt's views are without their flaws (not the least of which is the distinct possibility of a return to an order of Bismarckian realpolitik) ${ }^{20}$, but they do raise an interesting set of questions. What would have been the American public's reaction to the war had Americans known that it was, first and foremost, meant

\footnotetext{
${ }^{20}$ I will leave this point there. Delving into a discussion of what Schmitt's views mean for our understanding of what war should be used for is a thesis topic in its own right.
} 
to stop any hostile rogue power from gaining regional domination, so that an eventual clash with another superpower would be won by the US? How would have Americans responded through the election on November 5, 2004 had they known that one possibility was that the Iraq War was a mere prelude to a much larger and grander war? Who knows; but I, for one, would have liked the chance to see the American citizens' response to that question, rather than their response to the illusions of a 'just war' that was meant to spread democracy and freedom ${ }^{21}$. Finally, if the Iraq question were ever stated in this manner, how would the international community have responded? I think that talking about an issue that deals with an approaching clash of superpowers concerns everyone on the globe. Viewed in this light, America's decision over Iraq may not have seemed to be so concerned with a distinctly American problem after all.

Admittedly, it is too early to tell whether this mission will produce democracy, security, neither of the two, or both. One point, however, is certain: the ends internal to war-most important of which is the perpetuation of the conflict in Iraq - are likely to keep playing an important role in the upcoming cross-cultural interactions between America and the Middle East, and indeed between America and the world. This language of force does not simply disappear - it is not so easily forgotten. The discourse's architects already admit that the smooth transition between the two-steps can now be considered a misplaced assumption (PNAC website: Schmitt Sept. 2003, Donnelly \& Schmitt Oct. 2003, Kagan \& Kristol April 2004, Kagan May 2004, Kagan \& Kristol May

\footnotetext{
${ }^{21}$ The idea that illusions, rather than strategic interests, ought to be presented to the public to garner their support for state policy is visible in the discourse. For instance, in an interview in Vanity Fair, Paul Wolfowitz went as far as saying that "for bureaucratic reasons we settled on one issue, weapons of mass destruction, because it was the one everybody could agree on." (Quoted in Mamdani 2003: 357; emphasis added) Moreover, this idea is present in the Straussian teachings that many in the discourse were students of and/or adhere to.
} 
2004; Dick Cheney in Washington Post January 21,2005$)^{22}$. With this I agree, but the reason for this is not the insufficient number of troops; it was always the unpredictability, volatility, and ultimately, the inner-logic of the tool used: war.

As mentioned in Chapter One, the neoconservative internationalists argue that the creation of peaceful and reciprocal cross-cultural interactions is crucial to America's success in pursuing the isolationist dreams they seek. A serious question is thus being posed to the discourse now: forget about the smooth and quick transition from war to politics, or from the language of force to the language of understanding and diplomatic compromise. That assumption has clearly failed. But the following question the discourse must answer: just how is this transition, in the current circumstances, theoretically possible at all? If left unanswered (and currently, there does not seem to be a better answer than: replace Rumsfeld), this question will pose an insurmountable challenge for the discourse, and seriously dispute its viability as an intellectual basis for foreign policy making.

\footnotetext{
${ }^{22}$ Most of these statements were made when the war was only one year old. It is now two and one half years old, and there does not seem to be an end in sight!
} 


\section{Conclusion}

This thesis has investigated the neoconservative internationalist discourse. The first aim was to disentangle the various components which make up the discourse and operate within it. Second, it aimed to show how these components combined to create a vision and a strategy for America in the $21^{\text {st }}$ century. Third, it examined how a specific tactic was devised to deal with the Saddam question. Fourth, it engaged in a critical reflection on the discourse's plan towards Iraq in particular, and its defining features in general. What were the objectives behind all of this?

There are two objectives I aimed to accomplish in this task. The first involves my attempt to clarify what the driving forces behind the war effort entailed. I realize that many speculations exist regarding this question, and I do not claim that I have fully answered it. However it does point out a direction that may prove to be fruitful for explanation. This direction involves two important forces: the discourse's belief in American exceptionalism, and its perceived necessity for implementing change in a fast 'in-and-out' manner. The former made the use of war a 'morally justified act'; the latter facilitated the use of war as it was the fastest tool for implementing change.

The second objective involves a critical reflection on the fundamental aspect of the discourse that makes the neoconservative plan a theoretically viable one: the Clausewitzian view of war. Drawing on the works of Clausewitz and Foucault, I have argued that this view of war faces a paradox that is not easily overcome - indeed that it has not been overcome by either Clausewitz or the discourse. This paradox is simple, for it rests on one fundamental question: how can a tool of such power, force, impact, and 
duration always be subordinate to a higher political objective; especially when the war is fought between a strong and a weak side? My answer to this question is that war is not always subordinate to politics. I have argued that war has its own logic, as well as means and ends internal to it: I have stressed the other Clausewitzian view that war is a thing in and of itself. I have argued that the discourse's failure to see, let alone address, this paradox raises serious questions to the neoconservative plan for Iraq, and the discourse's viability as an intellectual basis for foreign policy making.

Through my discussion of these two objectives, I hope to have contributed to an understanding of war and its relationship to politics. This thesis has aimed to highlight the interconnectedness of these two spheres of human action. I have argued that our understanding of this relationship must include two concepts: domination and legitimacy. More specifically, I have pointed to the importance of understanding what war leaves behind for politics to deal with: forceful legitimacy. I believe that developing a better, and more nuanced, understanding of the relationship between war and politics is of paramount importance to the social sciences; and particularly to a sociological understanding of the very fabric that makes up the different modes of social organization.

It is now perhaps as good a time as any for social scientists to take a closer look at this relationship, and what better place to start than the Clausewitzian view of war that is predominant in Western military and political thinking? It is perhaps time to examine how close we are in our attempt to capture the complexities, inner workings, and features of war, and its complex relation to politics. Social scientists ought to test the possibility of combining the different conceptions of war that Clausewitz had outlined, and judge them against the conceptions of those who came before and after him. It is perhaps time 
we face this riddle head on, and begin the long process of unraveling it - it is clear to me that this process is already long overdue. 


\section{Bibliography:}

Art, Robert J. (2003). "A Grand Strategy for America". United States: Cornell University Press.

Barnett, Thomas P.M. (2004). "The Pentagon's New Map: War and Peace in the Twenty-first Century". United States: G.P. Putnam's Sons.

Bassford, Christopher (1994). "Clausewitz in English: The Reception of Clausewitz in Britain and America 1815-1945". United States: Oxford University Press.

Bennett, William (2000). "Morality, Character and American Foreign Policy", in Kagan, Robert \& Kristol, William (eds.) Present Dangers: Crisis and Opportunity in American Foreign and Defense Policy (2000). United States: Encounter Books.

Berger, Peter L. \& Luckmann, Thomas (1966). "The Social Construction of Reality: A Treatise in the Sociology of Knowledge". United States: Anchor Books.

Ceaser, James (2000). "The Great Divide: American Internationalism and its Opponents", in Kagan, Robert \& Kristol, William (eds.) Present Dangers: Crisis and Opportunity in American Foreign and Defense Policy (2000). United States: Encounter Books.

Chomsky, Noam (2003). "Wars of Terror", in Abrams, Irwin \& Gungwu, Wang (eds.) The Iraq War and its Consequences: Thoughts of Nobel Peace Laureates and Eminent Scholars (2003). England: World Scientific.

Clausewitz, Karl Von (1943). "On War", in The Book of War (2000). United States: The Modern Library.

Creighton, Colin \& Shaw, Martin (eds.) (1987). "The Sociology of War and Peace". England: Macmillan. 
Dominicè, Christian (2003). "Some Legal Aspects of the Military Operation in Iraq", in Abrams, Irwin \& Gungwu, Wang (eds.) The Iraq War and its Consequences: Thoughts of Nobel Peace Laureates and Eminent Scholars (2003). England: World Scientific.

Dower, John (2003). "Warning from History: Why Iraq is Not Japan", in Abrams, Irwin \& Gungwu, Wang (eds.) The Iraq War and its Consequences: Thoughts of Nobel Peace Laureates and Eminent Scholars (2003). England: World Scientific.

Fallows, James (2004). "Blind into Baghdad", in The Atlantic Monthly, Jan/Feb: 53-74. United States: Atlantic Monthly Co.

Ferguson, Niall (2004). "Colossus: The Price of America's Empire". United States: The Penguin Press.

Foucault, Michel (1972). "The Archaeology of Knowledge". England: Tavistock Publications.

Foucault, Michel (1977). "Language, Counter-Memory, Practice: Selected Essays and Interviews". Bouchard, Donald (ed). United States: Cornell University Press.

Foucault, Michel (2003). "Society must be Defended: Lectures at the Collège De France 1975-1976". Bertani, Ewald, Fontana (eds). United States: Picador.

Frum, David \& Perle, Richard (2003). “An End to Evil: How to Win the War on Terror". United States: Random House.

Furnivall, John S. (1956). "Colonial Policy and Practice: A Comparative Study of Burma and Netherlands India". United States: New York University Press.

Gallie, W.B. (1978). "Philosophers of Peace and War: Kant, Clausewitz, Marx, Engels and Tolstoy". United States: Cambridge University Press. 
Habermas, Jürgen (1984). "Communication and the Evolution of Society". England: Polity Press.

Hardt, Michael \& Negri, Antonio (2000). “Empire”. United States: Harvard University Press.

Hardt, Michael \& Negri, Antonio (2004). "Multitude: War and Democracy in the Age of Empire". United States: The Penguin Press.

Hartung, William \& Donnelley, Ceara (2003). "The Hidden Costs of War: How the Bush Doctrine is Undermining Democracy in Iraq and Democracy in America", in Abrams, Irwin \& Gungwu, Wang (eds.) The Iraq War and its Consequences: Thoughts of Nobel Peace Laureates and Eminent Scholars (2003). England: World Scientific.

Huntington, Samuel P. (1996). "The Clash of Civilizations and the Remaking of World Order". United States: Simon \& Schuster.

Jervis, Robert (2003). "Understanding the Bush Doctrine", in Political Science Quarterly, 118 (3), fall: 365-88. United States.

Joas, Hans (2003). "War and Modernity". United Kingdom: Polity Press.

Kagan, Donald (2000). "Strength and Will: A Historical Perspective", in Kagan, Robert \& Kristol, William (eds.) Present Dangers: Crisis and Opportunity in American Foreign and Defense Policy (2000). United States: Encounter Books.

Kagan, Frederick (2000). "The Decline of America's Armed Forces", in Kagan, Robert \& Kristol, William (eds.) Present Dangers: Crisis and Opportunity in American Foreign and Defense Policy (2000). United States: Encounter Books. 
Kagan, Robert \& Kristol, William (2000). "Introduction: National Interest and Global Responsibility", in Kagan, Robert \& Kristol, William (eds.) Present Dangers: Crisis and Opportunity in American Foreign and Defense Policy (2000). United States: Encounter Books.

Kagan, Robert (2003). "Of Paradise and Power: America and Europe in the New World Order". United States: Knopf.

Kaplan, Lawrence F.; Kristol, William (2003). "The War over Iraq: Saddam's Tyranny and America's Mission". United States: Encounter Books.

Klare, Michael (2003). “The New Geopolitics”, in Monthly Review, 53 (3), July-Aug: 51-56. United States.

Lilla, Mark (2004). "The Closing of the Straussian Mind", in The New York Review of Books, LI (17), Nov. 4: 55-59. United States: Rea S. Hederman.

Mamdani, Mahmood (2003). "Iraq: Collective Punishment in War and Peace", in Abrams, Irwin \& Gungwu, Wang (eds.) The Iraq War and its Consequences: Thoughts of Nobel Peace Laureates and Eminent Scholars (2003). England: World Scientific.

Mann, Michael (2003). "Incoherent Empire”. England-United States: Verso.

Perle, Richard (2000). "Iraq: Saddam Unbound", in Kagan, Robert \& Kristol, William (eds.) Present Dangers: Crisis and Opportunity in American Foreign and Defense Policy (2000). United States: Encounter Books.

Preuss, Ulrich K. (2003). "The Iraq War: Critical Reflections from 'Old Europe”, in Constellations, 10 (3), Sept: 339-351. United Kingdom. 
Roxborough, Ian (1994). "Clausewitz and the Sociology of War", in The British Journal of Sociology, 45 (4), Dec: 619-636. England: The London School of Economics and Political Science.

Scott, David (1995). "Colonial Governmentality", in Social Text, 43, fall: 191-220. United States.

Ullman, Harlan; Wade, James P. (1996). "Shock and Awe: Achieving Rapid Dominance". United States: Kessinger Publishing.

Ullman, Harlan; Wade, James P. (1998). "Rapid Dominance, a Force for All Seasons. Technologies and Systems for Achieving Shock and Awe: A Real Revolution in Military Affairs". England: Royal United Services Institute for Defence Studies.

Wolfowitz, Paul (2000). "Statesmanship in the New Century", in Kagan, Robert \& Kristol, William (eds.) Present Dangers: Crisis and Opportunity in American Foreign and Defense Policy (2000). United States: Encounter Books.

Woodward, Bob (2004). "Plan of Attack". United States: Simon \& Schuster.

Wright, Ronald (2004). "A Short History of Progress". Canada: Anansi.

Zagacki, Kenneth S. (1996). "The Priestly Rhetoric of Neoconservatism", in Western Journal of Communication, 60 (2), Spring: 168-187.

Žižek, Slavoj (2004). "Iraq: The Borrowed Kettle". United States: Verso. 


\section{Electronic Resources:}

Project for the New American Century - www.newamericancentury.org:

Project's Statement of Principles - June 3, 1997.

Project Archives:

- “Bombing Iraq Isn't Enough". William Kristol \& Robert Kagan, New York Times, January 30, 1998.

- “A 'Great Victory' For Iraq". William Kristol \& Robert Kagan, Washington Post, February 26, 1998.

- "Wolfowitz Statement on U.S. Policy Toward Iraq". Project Memorandum, Gary Schmitt, September 18, 1998.

- "How to Attack Iraq". The Weekly Standard Editorial, November 16, 1998.

- "Liberate Iraq". Reuel Marc Gerecht, The Weekly Standard, May 14, 2001.

- "Why Iraq?" Gary Schmitt, The Weekly Standard, October 19, 2001.

- "Vice President Cheney's Speech on Preemptive Military Action Against Iraq". Project Memorandum, William Kristol, August 26, 2002.

- "A Necessary War". Reuel Marc Gerecht, The Weekly Standard, October 14, 2002.

- “The UN Trap?" William Kristol \& Robert Kagan, The Weekly Standard, November 8, 2002.

- "Richard Perle on Iraq". Project Memorandum, Gary Schmitt, February 24, 2003.

- "Power \& Duty: U.S. Action is Crucial to Maintaining World Order". Gary Schmitt, Los Angeles Times, March 23, 2003.

- "Response to Asmus and Pollack". Gary Schmitt, July 24, 2003.

- "More Troops for Iraq". Gary Schmitt, September 5, 2003.

- "The Right Fight Now: Counterinsurgency, not Caution, is the Answer in Iraq". Tom Donnelly \& Gary Schmitt, Washington Post, October 26, 2003.

- "Too Few Troops". Robert Kagan \& William Kristol, The Weekly Standard, April $21,2004$. 
- “Lowering Our Sights”. Robert Kagan, Washington Post, May 2, 2004.

- "Democracy Now". Robert Kagan \& William Kristol, The Weekly Standard, May $11,2004$.

- "Birth of a Democracy". Reuel Marc Gerecht, The Weekly Standard, February 14, 2005.

Project Statements:

- "Letter to President Clinton on Iraq" January 26, 1998.

- "Letter to Gingrich and Lott on Iraq" May 29, 1998.

- "Statement on Post-War Iraq" March 19, 2003.

"The National Security Strategy of the United States of America" (2002). Electronic Resource: http://www.whitehouse.gov/nsc/nss.pdf. United States.

"The 9/11 Commission Report: Final Report of the National Commission on Terrorist Attacks upon the United States" (2004). Kean, Thomas H. (chair); Hamilton, Lee H. (vice chair). Electronic Resource: http://purl.access.gpo.gov/GPO/LPS51934. United States. 


\section{Appendix A}

In reference to the "poisonous cultural effects of tyranny" (Frum \& Perle 2003: 160), the authors write,

"Take a vast area of the earth's surface, inhabited by people who remember a great history. Enrich them enough that they can afford satellite television and Internet connections, so that they can see what life is like across the Mediterranean or across the Atlantic. Then sentence them to live in choking, miserable, polluted cities ruled by corrupt, incompetent officials. Entangle them in regulations and controls so that nobody can ever make much of a living except by paying off some crooked official. Subordinate them to elites who have suddenly become incalculably wealthy from shady dealings involving petroleum resources that supposedly belong to all. Tax them for the benefit of governments that provide nothing in return except military establishments that lose every war they fight: not roads, not clinics, not clean water, not street lighting. Reduce their living standards year after year for two decades. Deny theme any forum or institution-not a parliament, not even a city council—where they may freely discuss their grievances. Kill, jail, corrupt, or drive into exile every political figure, artist, or intellectual who could articulate a modern alternative to bureaucratic tyranny. Neglect, close, or simply fail to create an effective school system-so that the minds of the next generation are formed entirely by clerics whose own minds contain nothing but medieval theology and a smattering of third world nationalist self-pity. Combine all this, and what else would one expect to create but an enraged populace ready to transmute every frustration in its frustrating daily life into a fanatical hatred of everything "un-Islamic"?

This fetid environment nourishes the most venomous vermin in the Middle Eastern swamp."

(Frum \& Perle 2003: 160-161). 


\section{Appendix B}

"On March 4, [2003] Feith came to the White House and gave a secret briefing to the president and the NSC [National Security Council]. The full PowerPoint briefing listed these objectives:

- Iraq's territorial integrity is maintained and the quality of life in Iraq is improved visibly.

- Iraq is seen to be moving toward democratic institutions and serves as a model for the region.

- The U.S. and coalition maintain freedom of action to carry out the global war on terrorism and WMD capture and destruction activities.

- Obtain international participation in the reconstruction effort.

- Obtain the support of the Iraqi people.

- Obtain the political support of the international community, including the regional states, preferably through a U.N. Security Council resolution.

- Place as many Iraqi faces in positions of physical authority as quickly as possible.

- Accomplish the above urgently."

(Woodward 2004: 328) 